$$
\begin{array}{r}
\text { Pontifícia Universidade Católica } \\
\text { do Rio de Janeiro }
\end{array}
$$

Gabriel Calil Maia Tardelli

$$
\begin{array}{r}
\text { Lugar de pescador: } \\
\text { usos, apropriações e conflito em torno de um barracão de pesca } \\
\text { na Praia de Piratininga - Niterói (RJ) }
\end{array}
$$

Dissertação apresentada ao Programa de PósGraduação em Ciências Sociais da PUC-Rio como requisito parcial para obtenção do grau de Mestre em Ciências Sociais.

Orientador: Prof. Valter Sinder

Coorientador: Prof. Ronaldo Joaquim da Silveira Lobão

Rio de Janeiro 


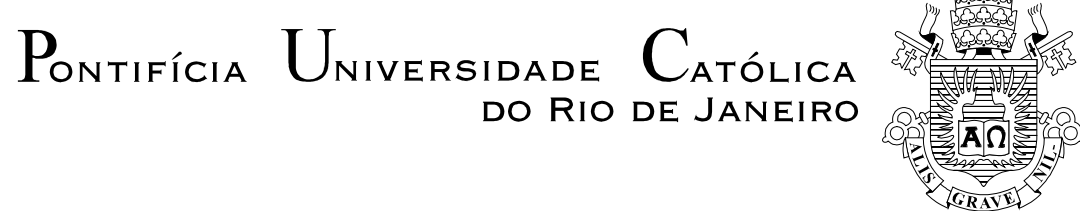

Gabriel Calil Maia Tardelli

\title{
Lugar de Pescador: Usos, Apropriações e Conflito em torno de um Barracão de Pesca na Praia de Piratininga \\ - Niterói (RJ)
}

Dissertação apresentada como requisito parcial para obtenção do grau de Mestre pelo Programa de PósGraduação em Ciências Sociais do Departamento de Ciências Sociais do Centro de Ciências Sociais da PUC-Rio. Aprovada pela Comissão Examinadora abaixo assinada.

\author{
Prof. Valter Sinder \\ Orientador \\ Departamento de Ciências Sociais - PUC-Rio
}

Prof. Ronaldo Joaquim da Silveira Lobão

Co-orientador

UFF

Prof. Fabio Reis Mota

UFF

Profa. Sonia Maria Giacomini Departamento de Ciências Sociais - PUC-Rio

Profa. Mônica Herz

Coordenadora Setorial do Centro de Ciências Sociais - PUC-Rio

Rio de Janeiro, 05 de maio de 2017 
Todos os direitos reservados. É proibida a reprodução total ou parcial do trabalho sem autorização do autor, do orientador e da universidade.

\section{Gabriel Calil Maia Tardelli}

Mestrando em Ciências Sociais pela Pontifícia Universidade Católica do Rio de Janeiro (PUC-RJ); bacharel em Direito pela Universidade Federal Fluminense (UFF); bacharel em Comunicação Social, habilitação Jornalismo, pelas Faculdades Integradas Hélio Alonso (FACHA). Atua no campo da Antropologia do Direito. Interessa-se por questões relacionadas à justiça socioambiental, à construção legal de identidades e à administração de conflitos. Desenvolve pesquisas que têm como objeto os seguintes contextos: neocolonialismo, direitos dos povos ou comunidades tradicionais e conflitos em unidades de conservação ambiental. É pesquisador no Núcleo de Pesquisa sobre Práticas e Instituições Jurídicas (NUPIJ-UFF), vinculado ao Instituto de Estudos Comparados em Administração Institucional de Conflitos (INCT-InEAC).

Ficha Catalográfica

Tardelli, Gabriel Calil Maia

Lugar de pescador: usos, apropriações e conflito em torno de um barracão de pesca na Praia de Piratininga - Niterói (RJ) / Gabriel Calil Maia Tardelli; orientador: Valter Sinder; co-orientador: Ronaldo Joaquim da Silveira Lobão. 2017.

145 f.: il. color. ; $30 \mathrm{~cm}$

Dissertação (mestrado)-Pontifícia Universidade Católica do Rio de Janeiro, Departamento de Ciências Sociais, 2017.

Inclui bibliografia

1. Ciências Sociais - Teses. 2. Pesca artesanal. 3. Espaço público. 4. Administração de conflitos. I. Sinder, Valter. II. Lobão, Ronaldo Joaquim da Silveira. III. Pontifícia Universidade Católica do Rio de Janeiro. Departamento de Ciências Sociais. IV. Título. 


\section{Agradecimentos}

A despeito da insistência dos ideólogos individualistas, a coletividade se manifesta mesmo em trabalhos supostamente solitários. Nesse sentido, esta dissertação foi co-escrita direta ou indiretamente por muitas pessoas.

Agradeço, assim, ao Programa de Pós-Graduação em Ciências Sociais da Pontifícia Universidade Católica (PPGCIS-PUC-RJ), pela recepção acolhedora e pela formação que me foi dada. À Coordenação de Aperfeiçoamento de Pessoal de Nível Superior (CAPES), que tornou possível a realização desta pesquisa mediante a concessão de uma bolsa de mestrado.

Aos professores Roberto DaMatta e Maria Sarah da Silva Telles, cujas observações ajudaram a clarear o objeto desta pesquisa. Agradeço, do mesmo modo, às questões levantadas e às sugestões dadas pelos antropólogos José Colaço e Francisca Miller, em uma reunião científica.

Ao meu orientador Valter Sinder, que abraçou esta pesquisa, ainda que aquela não fosse sua "praia" e com quem tenho aprendido sobre os meandros da disciplina antropológica. Ao meu coorientador e orientador de longa data, Ronaldo Lobão, que tem me ensinado a duvidar mesmo das certezas mais indubitáveis, que não me deixa esquecer dos caminhos já percorridos e que me serve de inspiração para o exercício de uma antropologia crítica.

Aos membros da banca, Sonia Giacomini e Fábio Reis Mota, cujos comentários, críticas e sugestões foram de grande valia na sistematização, organização e delineamento deste trabalho.

A todos os membros do Núcleo de Pesquisas sobre Práticas e Instituições Jurídicas (NUPIJ) da Universidade Federal Fluminense (UFF), em especial ao meu amigo Bruno Mibielli, cujos estímulos e oportunidades têm contribuído para que eu tenha cada vez mais prazer em fazer trabalho de campo; à amiga Izabela Fernandes, que, embora, como eu, queira "abraçar o mundo com as pernas", dedicou parte de seu tempo à leitura e correção deste texto; à amiga Luciana Loto e aos amigos Ismael Stevenson e Allan Sinclair, que de alguma forma também estiveram presentes. 
Agradeço à amiga Marina Schneider, que se mostrou solidária, mesmo sem me conhecer, e com quem tenho uma dívida impagável; à amiga Ana Carolina Radd e ao amigo Marcos Milner, que leram este texto e teceram comentários preciosos.

Agradeço ao meus pais, Débora e Júlio, sempre presentes, mesmo quando o filho opta pelos descaminhos da vida: vocês são fundamentais! E aos meus irmãos, Eduardo e Júlia, tão diferentes, porém, paradoxalmente, tão iguais a mim.

À minha namorada, companheira, esposa - ou qualquer designação que possa ser dada à mulher amada - Aline Lessa ("a porção melhor que trago em mim agora"), que se manteve firme na embarcação, mesmo quando o naufrágio parecia inevitável. Sobrevivemos!

Agradeço, por fim, aos amigos que fiz em Piratininga, especialmente Cléber e Kiko, razão pela qual este trabalho vem a público.

A todos você que me modificaram - e acredito que também os tenha modificado , ofereço esta dádiva como forma de retribuição. 


\section{Resumo}

Tardelli, Gabriel Calil Maia; Sinder, Valter. Lugar de pescador: usos, apropriações e conflito em torno de um barracão de pesca na Praia de Piratininga - Niterói (RJ). Rio de Janeiro, 2017. 145p. Dissertação de Mestrado - Departamento de Ciências Sociais, Pontifícia Universidade Católica do Rio de Janeiro.

O foco desta dissertação recai sobre os múltiplos usos e apropriações de um espaço - o barracão de pesca - através de uma situação específica: o conflito envolvendo pescadores que exercem diferentes artes de pesca e barraqueiros, na Praia de Piratininga, em Niterói (RJ). Primeiramente, a partir do trabalho de campo, descrevo a localidade e os atores envolvidos, assim como as disputas que ocorrem na praia, sobretudo com a aproximação do verão. Em um segundo momento, tento responder, com o auxílio de conceitos e teorias, as questões suscitadas pela pesquisa empírica, que dizem respeito à noção de espaço público no Brasil, as representações sobre a praia, os interesses em jogo e os sentidos atribuídos a esse lugar. Finalizo com uma análise interpretativa do conflito que permeia a estrutura política do grupo e dos mecanismos utilizados para administrá-lo.

\section{Palavras-chave}

Pesca Artesanal; Espaço Público; Administração de Conflitos. 


\section{Abstract}

Tardelli, Gabriel Calil Maia; Sinder, Valter (Advisor). Fisherman's Place: Uses, Appropriations and Conflict around a Fishing Shed at Piratininga Beach - Niterói (RJ). Rio de Janeiro, 2017. 145p. Dissertação de Mestrado - Departamento de Ciências Sociais, Pontifícia Universidade Católica do Rio de Janeiro.

The focus of this master thesis lies on the multiple uses and appropriations regarding a space - the fishing shed - through a specific situation: the conflict involving fishermen who practice different fishing gear and "barraqueiros", in Piratininga Beach, Niterói, RJ. Firstly, from the fieldwork, I describe the locality and the actors involved, as well as the disputes that occur on the beach, especially as summer approaches. Posteriorly, I try to answer, through concepts and theories, the questions raised by empirical research, regarding the notion of public space in Brazil, the representations about the beach, the interests at stake and the meanings attributed to that place. Finally, I conclude with an interpretive analysis of the conflict that is present in the political structure of the group and the mechanisms used to manage it.

\section{Keywords}

Handcraft Fishing; Public Space; Conflict Management. 


\section{Sumário}

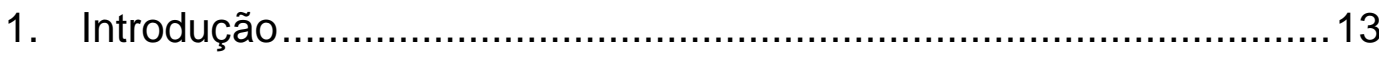

2. Cenários e cenas de um drama ....................................................... 18

2.1. Caminhos e descaminhos: introdução ao trabalho de campo .....18

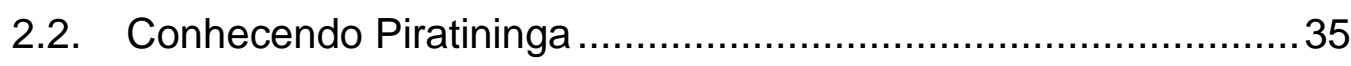

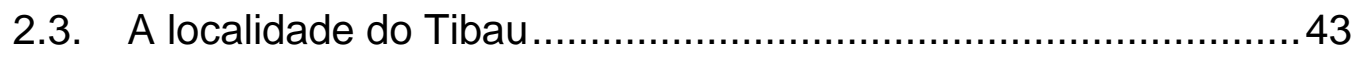

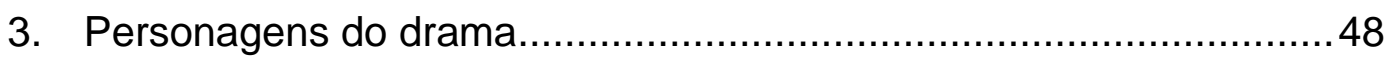

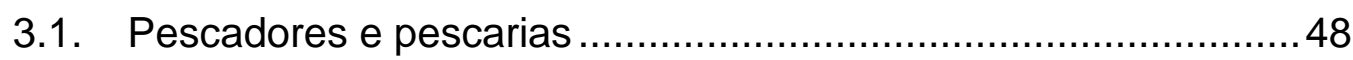

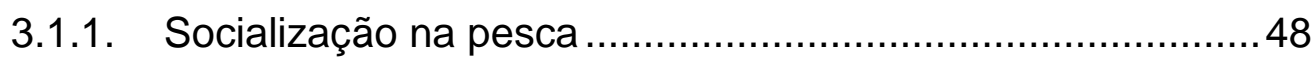

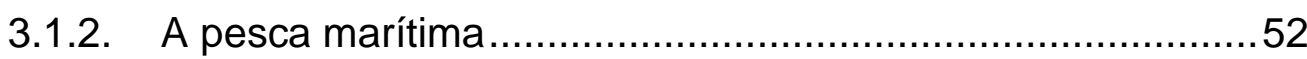

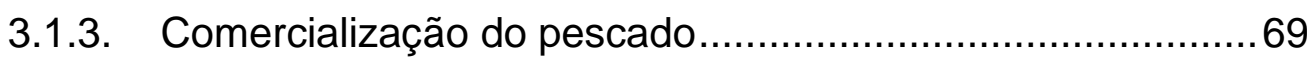

3.1.4. A pesca lagunar ............................................................ 70

3.2. Barraqueiros e barracas de sol .............................................. 74

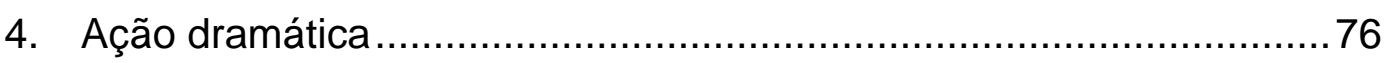

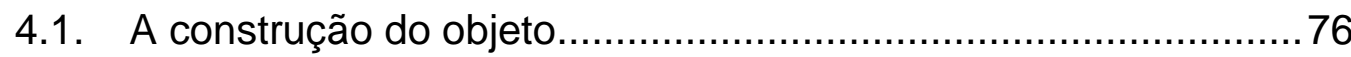

4.2. O barracão de pesca............................................................

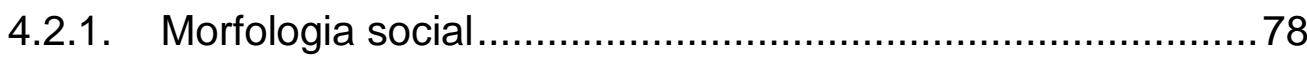

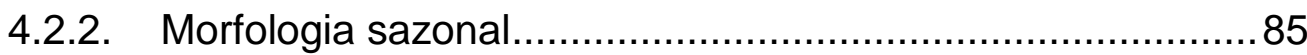

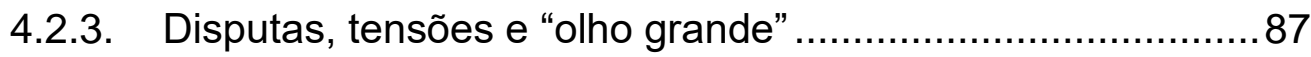

4.3. Muitos sentidos, pouco consenso ….........................................91

5. Quem define o quê, quando, onde e como? ...................................101

5.1. Espaços, lugares e visões de mundo ........................................102

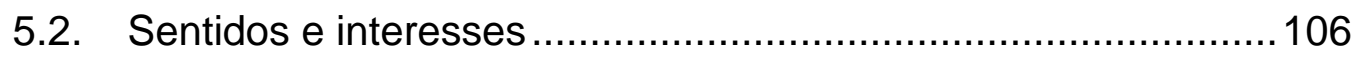

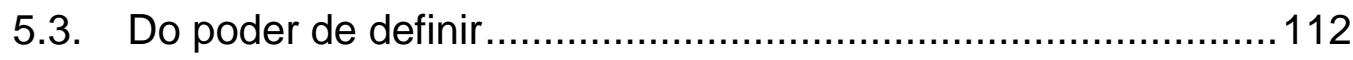

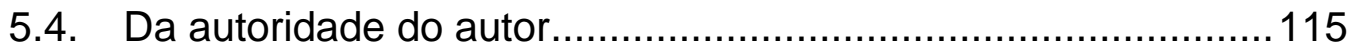

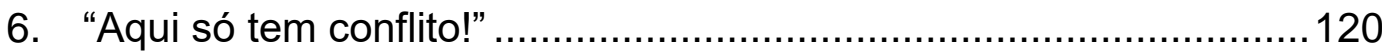

6.1. A natureza sociológica do conflito .........................................120

6.2. O dilema do espaço público brasileiro.......................................123

6.3. Dramas sociais ou conflitos intratáveis? ..................................126

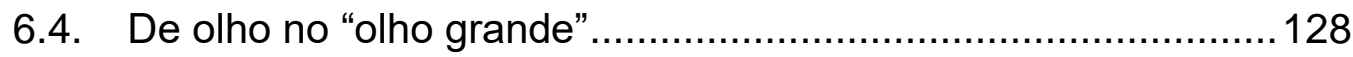

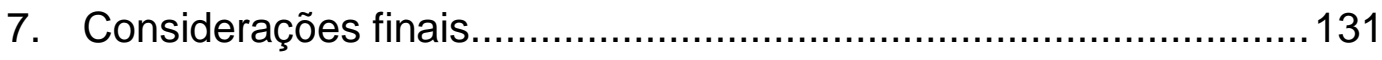

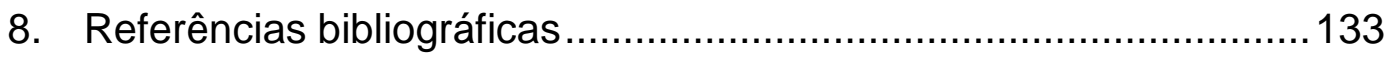

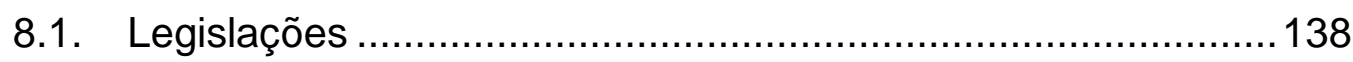

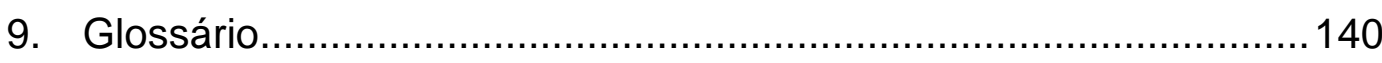




\section{Siglas}

Alpagoa - Associação Livre de Pesca e Amigos da Praia e Lagoa de Piratininga

Biomar - Biologia Marinha da Universidade Federal Fluminense

CNPT - Centro Nacional de Desenvolvimento Sustentado das Populações Tradicionais

ECQ - Estudo de Componente Quilombola

IBAMA - Instituto Brasileiro do Meio Ambiente e dos Recursos Naturais Renováveis

ICMBio - Instituto Chico Mendes de Conservação da Biodiversidade

INEA - Instituto Estadual do Ambiente

Nupij - Núcleo de Pesquisas sobre Práticas e Instituições Jurídicas

PUC-RJ - Pontifícia Universidade Católica do Rio de Janeiro

PPGCIS-RJ - Programa de Pós-Graduação em Ciências Sociais da PUCRJ

Resex-Mar Itaipu - Reserva Extrativista Marinha de Itaipu

SPU - Secretaria de Patrimônio da União

TAUS - Termo de Autorização de Uso Sustentável

UFF - Universidade Federal Fluminense 


\section{Lista de figuras}

Figura 1 - Manchete sobre incêndio ………………......................19

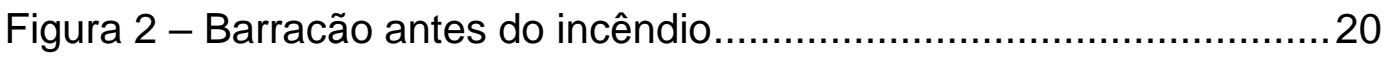

Figura 3 - Mapa georreferenciado do barracão ………………….......... 21

Figura 4 - Seu Euclides reformando uma canoa ...................................22

Figura 5 - Enseada da Prainha vista lateral do barracão .........................23

Figura 6- Apresentação do estudo de caracterização pelo antropólogo

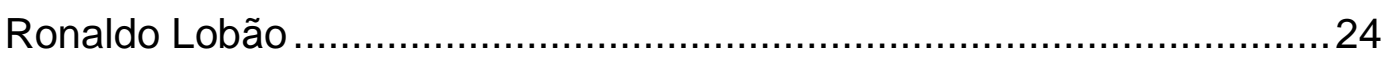

Figura 7 - Exemplo de "roda" com os prognósticos de pescarias da llha

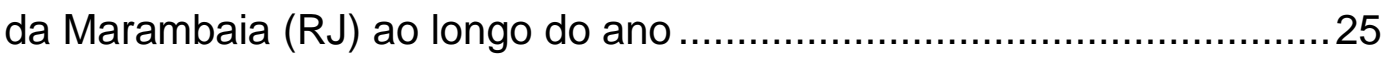

Figura 8 - Operação de encalhar a canoa sobre as estivas. ...................26

Figura 9 - Aniversário do Lulu no barracão........................................27

Figura 10 - Reconfiguração do barracão (vista da Ponta da Galheta). ....30

Figura 11 - Lateral do barracão próxima à Ponta da Galheta. ..................31

Figura 12 - Construção do "quiosque" da ilhota.......................................34

Figura 13 - Mapa das praias oceânicas de Niterói. ...................................35

Figura 14 - Mapa do Canal do Camboatá. ............................................39

Figura 15 - Descrição dos cenários paisagísticos da Prainha segundo

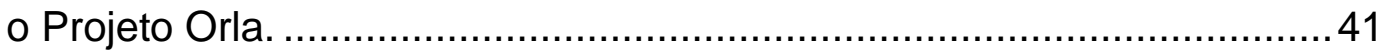

Figura 16 - Mapa da situação da Resex Itaipu. ......................................43

Figura 17 - Mapa da localidade do Tibau. .............................................. 44

Figura 18 - Pescador tarrafeando na lagoa (vista da ponte). ................... 45

Figura 19 - Conversa no Tibau na beira da lagoa (Kiko e Seu Vadinho). 46

Figura 20 - Kátia, amiga dos pescadores, ajudando na limpeza do

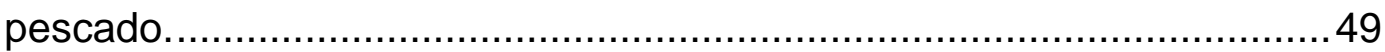

Figura 21 - Canoa "Começo da Vida"...................................................53

Figura 22 - Cléber coordena as etapas finais do cerco. ..........................58

Figura 23 - Rogério e seu filho Daniel tentam entrar no mar durante o

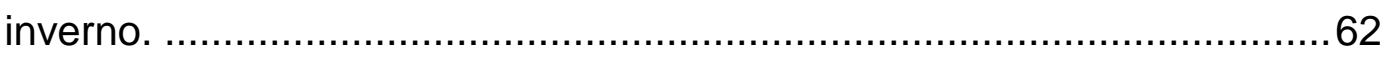

Figura 24 - Limpeza de peixes na beira da praia....................................69

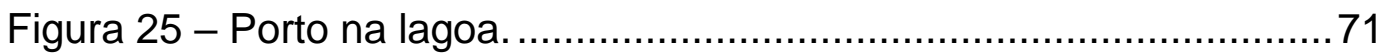

Figura 26 - Trico desembarcando em seu porto, situado em frente à sua casa. 
Figura 27 - Barco e canoa disputando o espaço com mesas e cadeiras. 75

Figura 28 - Barracão visto da Pedra da Galheta. ................................. 79

Figura 29 - Barracão utilizado para armazenar embarcação e redes......81

Figura 30 - Barracão utilizado para celebrar uma festa de aniversário. ..81

Figura 31 - Oratório com imagens de Santa Sara. ..................................82

Figura 32 - Cabana situada na restinga. ........................................... 83

Figura 33 - Congestionamento de embarcações durante o verão............86

Figura 34 - Trico consertando uma rede de tarrafa na lateral do

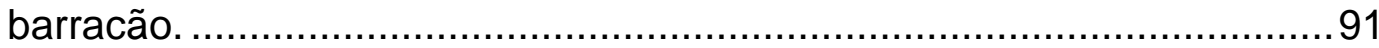

Figura 35 - Cantina situada no barracão de pesca.................................93

Figura 36 - Desenho do barracão antes do incêndio................................94

Figura 37 - Esquema de objetos simbólicos dos pescadores de

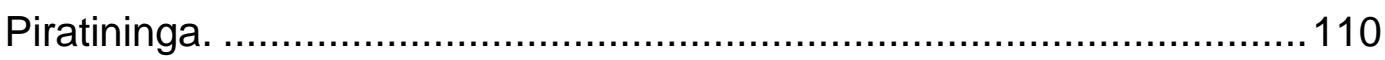

Figura 38 - Objeto simbólico representando sentidos distintos para

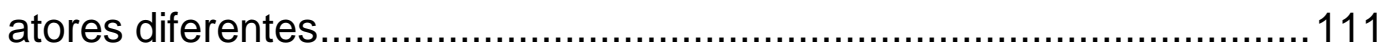

Figura 39 - Pirâmide engastalhada em um paralelepípedo. ...................125 
Fazer o que seja é inútil.

Não fazer nada é inútil.

Mas entre fazer e não fazer mais vale o inútil do fazer.

Mas não, fazer para esquecer que é inútil: nunca o esquecer.

Mas fazer o inútil sabendo que ele é inútil e que seu sentido não será sequer pressentido, fazer: porque ele é mais difícil do que não fazer, e dificilmente se poderá dizer com mais desdém, ou então dizer mais direto ao leitor Ninguém que o feito o foi para ninguém.

(João Cabral de Melo Neto,

"O Artista Inconfessável").

(...) de que adiantaria falar de motivos, às vezes basta um só, outras vezes nem juntando todos, se as vidas de cada um de vocês não vos ensinaram isto, coitados, e digo vidas, não vida, porque temos várias, felizmente vão-se matando umas às outras, senão não poderíamos viver.

(José Saramago, A Jangada de Pedra). 


\section{1.}

\section{Introdução}

Além de estampar cartões postais mundo afora, o litoral do estado do Rio de Janeiro tem figurado em muitos trabalhos acadêmicos. Refiro-me, mais precisamente, a uma tradição de estudos sobre pesca e pescadores, que é uma das marcas da antropologia fluminense (KANT DE LIMA et al, 2007). O presente trabalho filia-se a essa tradição e, ao olhar para Piratininga, no município de Niterói, almeja contribuir para o enriquecimento das pesquisas até o momento empreendidas.

No que diz respeito à Região Oceânica de Niterói, a localidade de Itaipu foi contemplada com inúmeros trabalhos (KANT DE LIMA; PEREIRA, 1997; PESSANHA, 2003; MIBIELLI, 2004). Já Piratininga apareceu na premiada dissertação Tudo que tem na terra tem no mar: a classificação dos seres vivos entre trabalhadores da pesca em Piratininga, de Gláucia Oliveira da Silva (1989), assim como na monografia Saber pescar, saber trabalhar: uma discussão sobre a identidade social dos pescadores de rede de arrastão na praia de Piratininga, de Joana Martins Saraiva (2004).

O problema central deste trabalho que ora apresento são os diferentes usos e apropriações de um barracão de pesca situado na Praia de Piratininga, com o foco voltado para uma situação específica: o conflito entre pescadores que exercem diferentes artes de pesca e barraqueiros, isto é, homens e mulheres que vendem comidas e bebidas na praia, dispondo sobre as areias mesas cadeiras e barracas, principalmente durante o verão. $\mathrm{O}$ objeto em disputa é o próprio barracão e a área que o circunda.

Para compreender o conflito, reuni uma série de significados que são atribuídos àquele espaço, que é percebido de diferentes maneiras, a depender dos contextos, dos atores e dos interesses envolvidos. Entendo que a luta simbólica pela definição de sentidos é, antes de tudo, uma luta política de poder, que afronta o princípio hierárquico que permeia a estrutura do grupo. Hierarquia, aqui, deve ser entendida como a relação das partes com o todo, e não como relações de mando e obediência (DUMONT, 1993; 2008). A invenção/imposição de um dado sentido 
está relacionada com as formas de se legitimar a ocupação do barracão e, como consequência, com os usos e apropriações sancionados.

Os participantes não compartilham as mesmas representações do objeto da contenda, de modo que, mais do que um drama social (TURNER, 2008), o conflito em Piratininga adquire a feição de um conflito intratável, que se perpetua no tempo e no espaço, a despeito da mudança dos atores e do objeto em disputa. Como conflito intratável, ele nunca cessa completamente, havendo apenas uma aparente resolução (LOBÃO, 2014, p. 45).

Enquanto método de exposição tentei adotar, na medida do possível, a proposta antropológica de Louis Dumont, dividindo a dissertação em três partes: Reunir, Compreender e Reconstruir (DUMONT, 1993, p. 224; LOBÃO, 2010, p. 14). No entanto, ressalto que, apesar de separadas, essas três partes estão conectadas. Assim, se o Reconstruir está vinculado à Compreensão, esta se liga ao Reunir: as etapas reportam-se e referenciam-se mutuamente.

Entendo por Reunir o trabalho de campo propriamente dito. Nessa parte, apresentarei os caminhos e descaminhos percorridos, de modo que o leitor possa me acompanhar com o mesmo conhecimento que acumulei paulatinamente, conforme as relações entre os pescadores e eu eram construídas. Ao separar o material empírico das demais partes, acredito que o mesmo poderá ser utilizado em outras ocasiões, pois o tratamento analítico e interpretativo que dei não irá engessálo. Outras veredas poderão ser abertas, por mim ou por outros autores.

Esta parte corresponde, portanto, à descrição dos processos sociais, que "significa a operação da vida social, a maneira pela qual as ações e a própria existência de cada ser vivo afetam a dos outros indivíduos com os quais ele se relaciona" (FIRTH, 1974, p. 20). No Capítulo 2 (“Cenários e cenas de um drama”), descrevo a paisagem local, isto é, a Praia de Piratininga e algumas localidades próximas que julguei importantes, quer por haver uma grande circulação de pescadores, parentes e amigos, quer por ter tido a oportunidade de conhecê-las. Com uma lente diacrônica, reuni alguns eventos que estão presentes na memória vivida dessas pessoas.

No Capítulo 3, intitulado "Personagens do drama", descrevo a atuação dos pescadores e dos barraqueiros naquele cenário, assim como as interações que ocorrem entre eles. Há, igualmente, um tópico dedicado às artes de pesca e a algumas formas de socialização que dizem respeito à vida dos pescadores. Esse 
empreendimento possibilitou que o objeto ficasse mais delineado, na medida em que os discursos enunciados relacionam e justificam as ocupações com os papeis que são desempenhados hierarquicamente.

Em seguida, o Capítulo 4 (“Ação dramática”) apresenta o barracão enquanto uma categoria local e uma construção dotada de uma historicidade; de forma alguma atemporal. Tentei reunir, aqui, algumas de suas camadas. Para tanto, foi imprescindível observar as transformações pelas quais o espaço passa no decorrer da alternância sazonal entre inverno e verão, duas estações repletas de significados e implicações na ocupação do barracão. O conflito entre pescadores e barraqueiros é explicitado durante o verão, período durante o qual a praia recebe um enorme contingente de banhistas (moradores de Piratininga ou de outras localidades), ou seja, quando aumentam as possibilidades de se obter maiores rendimentos.

Durante todo o trabalho de campo, muitas pessoas e ocasiões foram imprescindíveis para que eu pudesse formular questões e compreender melhor minhas observações. Meu orientador Valter Sinder me ouvia atentamente, ponderando e indicando leituras que pudessem me auxiliar. Sempre que possível, levava minhas aflições às reuniões do Núcleo de Pesquisas sobre Práticas e Instituições jurídicas (Nupij), sobre o qual falarei maias abaixo. Lá, meu coorientador Ronaldo Lobão e meus colegas opinavam e levantavam provocações. As conversas com os professores da pós-graduação Maria Sarah da Silva Telles e Roberto DaMatta também contribuíram para clarear minhas ideias. Do mesmo modo, quando da qualificação do meu projeto, ouvi atentamente as críticas e sugestões dos professores Sonia Giacomini e Fábio Reis Mota.

Mantive também um antigo hábito jornalístico e pedi para que amigos lessem o que eu estava escrevendo. Assim, além dos meus orientadores, recebi comentários da Ana Carolina Radd, da Izabela Fernandes e do Marcos Milner. Ademais, apresentei, previamente, algumas reflexões em reuniões científicas. ${ }^{1}$

Dessa forma, nesta segunda parte, Compreender, busco, a partir do que reuni durante o trabalho de campo, elaborar as questões centrais que me inquietaram, motivo pelo qual dei o seguinte título ao Capítulo 5: "Quem define o quê, quando, onde e como?". Nesse momento, utilizo conceitos, análises e teorias que podem

\footnotetext{
${ }^{1}$ Ver Tardelli (2016) e Tardelli; Stevenson (2016).
} 
ajudar na compreensão de algumas dessas questões. Ressalto, desde já, que não tenho a pretensão de explicar o mundo social; meu objetivo é tentar compreendêlo.

Por fim, na última parte, farei a minha interpretação do vivido em conceitos abrangentes, projetando algumas propostas (LOBÃO, 2010, p. 13-14). A etapa do Reconstruir compreende o Capítulo 6, cujo título faz referência a uma das interjeições que ouvi na praia: “Aqui só tem conflito!”. Nesse sentido, tento definir o conflito na Praia de Piratininga, a partir de algumas discussões sociológicas (DURKHEIM, 2013; SIMMEL, 1983) e de algumas interpretações acerca da maneira pela qual a sociedade brasileira lida com o conflito (DAMATTA, 1997; LOBÃO, 2000; KANT DE LIMA, 2010).

A fim de facilitar a leitura, as categorias dos interlocutores serão escritas em itálico nas primeiras e mais significativas vezes em que ocorrerem. Os significados dessas categorias aparecerão no decorrer do texto ou em notas de rodapé. Não obstante, o leitor poderá consultar um glossário ao final do trabalho. As aspas serão utilizadas para falas e citações dentro do texto. 


\section{PRIMEIRA PARTE:}

REUNIR 


\section{2.}

\section{Cenários e cenas de um drama}

\section{1.}

\section{Caminhos e descaminhos: introdução ao trabalho de campo}

Minha entrada no campo está atrelada à minha trajetória dentro da Faculdade de Direito da Universidade Federal Fluminense (UFF), na condição de graduando. Como membro do Núcleo de Pesquisas sobre Práticas e Instituições Jurídicas (Nupij), sediado na mesma faculdade, tenho participado, desde 2012, de pesquisas referentes a conflitos socioambientais, que envolvem as denominadas “populações tradicionais”. O núcleo, coordenado pelo antropólogo Ronaldo Lobão, coorientador desta dissertação, tem como marca a interdisciplinaridade e conta com pesquisadores de diferentes áreas, como a Antropologia, a Sociologia, a Biologia e, é claro, o Direito. Sob essa perspectiva, este trabalho é fruto de um processo de socialização na produção de pesquisa acadêmica.

Ressalto, já que se trata de uma variável da pesquisa, que o trabalho de campo foi realizado paralelamente ao término da minha graduação em Direito e à dedicação às disciplinas do mestrado em Ciências Sociais, na Pontifícia Universidade Católica do Rio de Janeiro (PUC-RJ). Os trajetos percorridos de ônibus da minha casa, no bairro de Icaraí (Niterói), até Piratininga (aproximadamente 1h30) e da minha casa até a PUC (em média 3h), no bairro da Gávea (RJ), mostraram-se longos e, muitas vezes, cansativos. Não obstante, no segundo semestre de 2016, dei aula em uma disciplina do curso de Segurança Pública da UFF e participei de um Estudo de Componente Quilombola (ECQ) na Ilha da Marambaia (RJ). Isso não me exime de equívocos e imperfeições, mas deixa transparecer que não houve uma imersão plena no campo - se é que isso seja possível.

Além da área jurídica, sou graduado em Comunicação Social, tendo atuado como jornalista. Longe de querer - e poder - me desvencilhar dessas formações, acredito que o texto que você lerá seja uma espécie de síntese de três formas de escrita bastante distintas: a escrita forense, a escrita jornalística e a escrita antropológica. Dito isso, vejamos como fui parar em Piratininga. 
No dia $1^{\circ}$ de setembro de 2014, o jornal $O$ Fluminense noticiou que o barracão de pesca da Praia de Piratininga havia sofrido um incêndio, na última sexta-feira à noite. Agentes da $81^{\mathrm{a}} \mathrm{DP}$ (Itaipu) investigavam o ocorrido. A reportagem trazia depoimentos dos pescadores a respeito das perdas e dos danos provocados pelo fogo: “Ontem pela manhã, ainda era possível notar alguns pequenos focos de incêndio no local e fumaça. Cerca de 15 pescadores que utilizavam o depósito perderam todo seu estoque, que incluía materiais usados para pesca e alguns barcos" (O FLUMINENSE, 2014).

Figura 1 - Manchete sobre incêndio

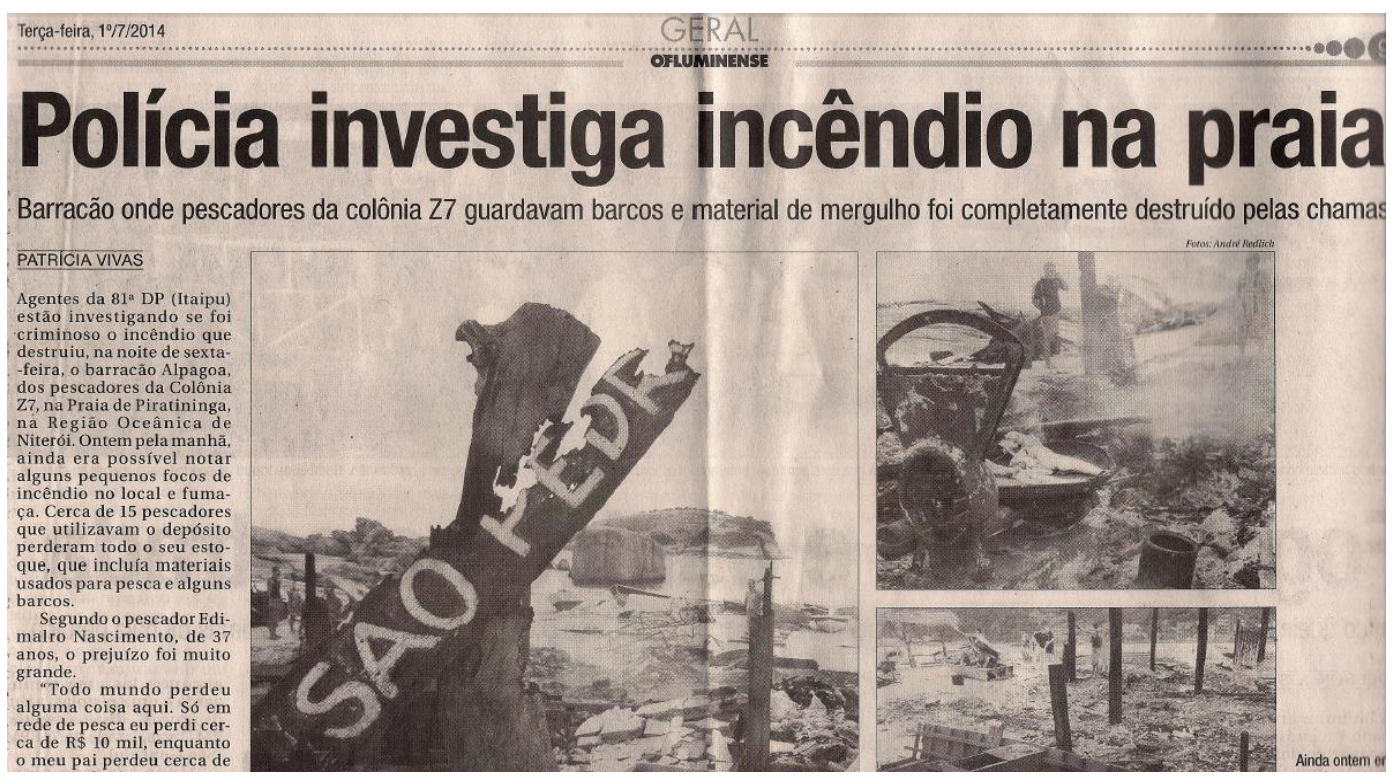

Fonte: O FLUMINENSE, 2014.

O barracão está localizado entre o calçadão e o mar, nas areias da Prainha, a parte menor da Praia de Piratininga; a maior é chamada localmente de Praião. Foi erguido de maneira improvisada, com diferentes tipos de materiais: pedaços de madeira, restos de embarcações, bambus, palhas de coqueiro, telhas, cordames, fios etc.

Materialmente, foi construído e reconstruído inúmeras vezes. Foi derrubado, incendiado e sofreu com as intempéries do mar. É um espaço destinado a diferentes finalidades, a depender dos atores e do contexto: pode servir para armazenar petrechos e embarcações; para a realização de reuniões da Associação Livre de Pesca e Amigos da Praia e Lagoa de Piratininga (Alpagoa); para festas de 
aniversário dos pescadores ou de familiares e amigos; para limpar ou vender o pescado; ou para "fazer comércio", isto é, vender comidas e bebidas.

Sob essa perspectiva, friso, antes de prosseguirmos, que a palavra barracão será trabalhada aqui como uma categoria local dotada de uma historicidade, não como algo atemporal.

Figura 2 - Barracão antes do incêndio

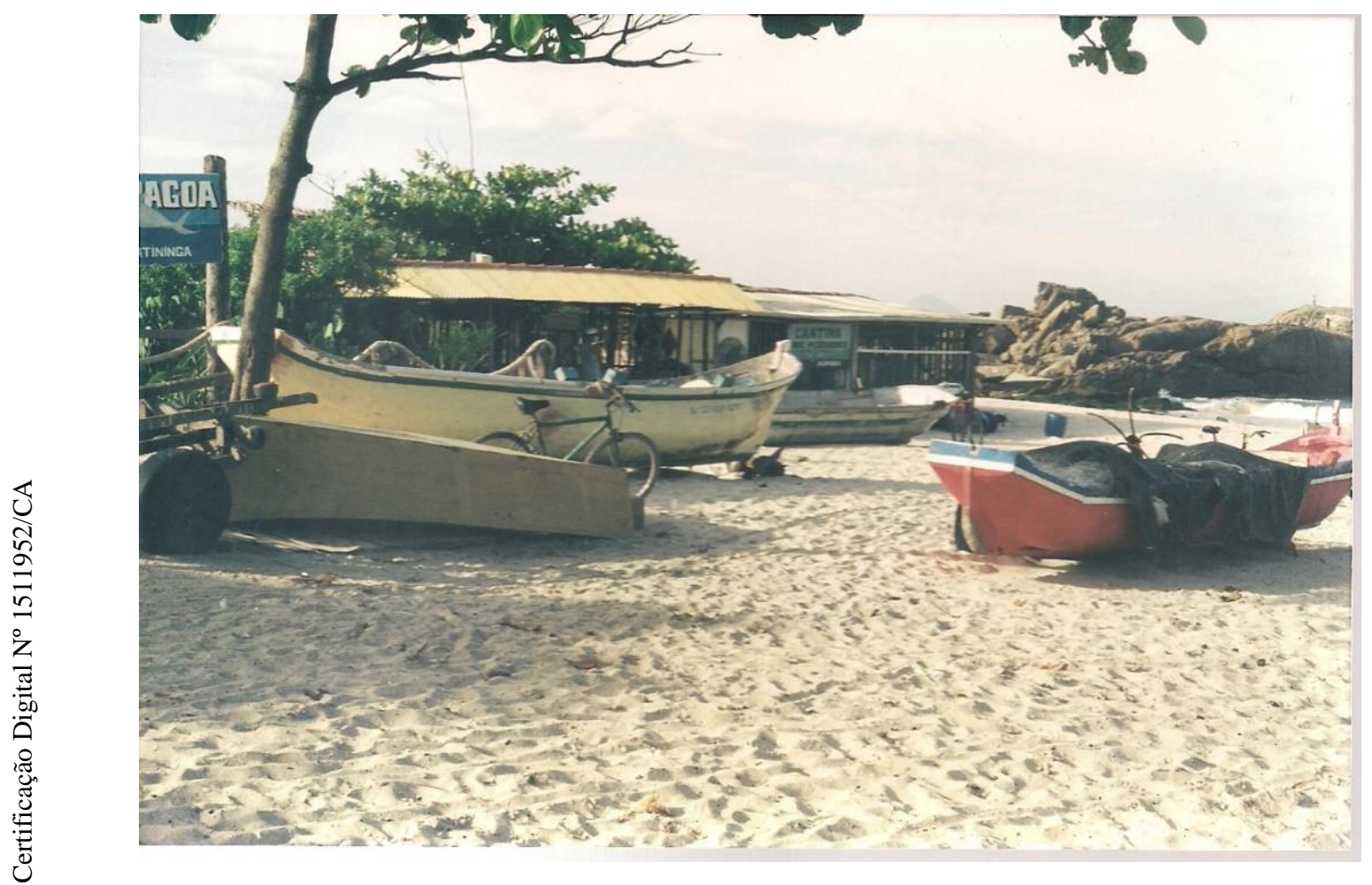

Fonte: Acervo Alpagoa.

Em conformidade com o georreferenciamento realizado pelo Nupij, a construção está situada em uma área com 2.331,02 m², levando-se em consideração o trecho de areia onde ficam algumas embarcações (lado direito de quem chega à praia) e a vegetação que se encontra na parte de trás do barracão. 
Figura 3 - Mapa georreferenciado do barracão

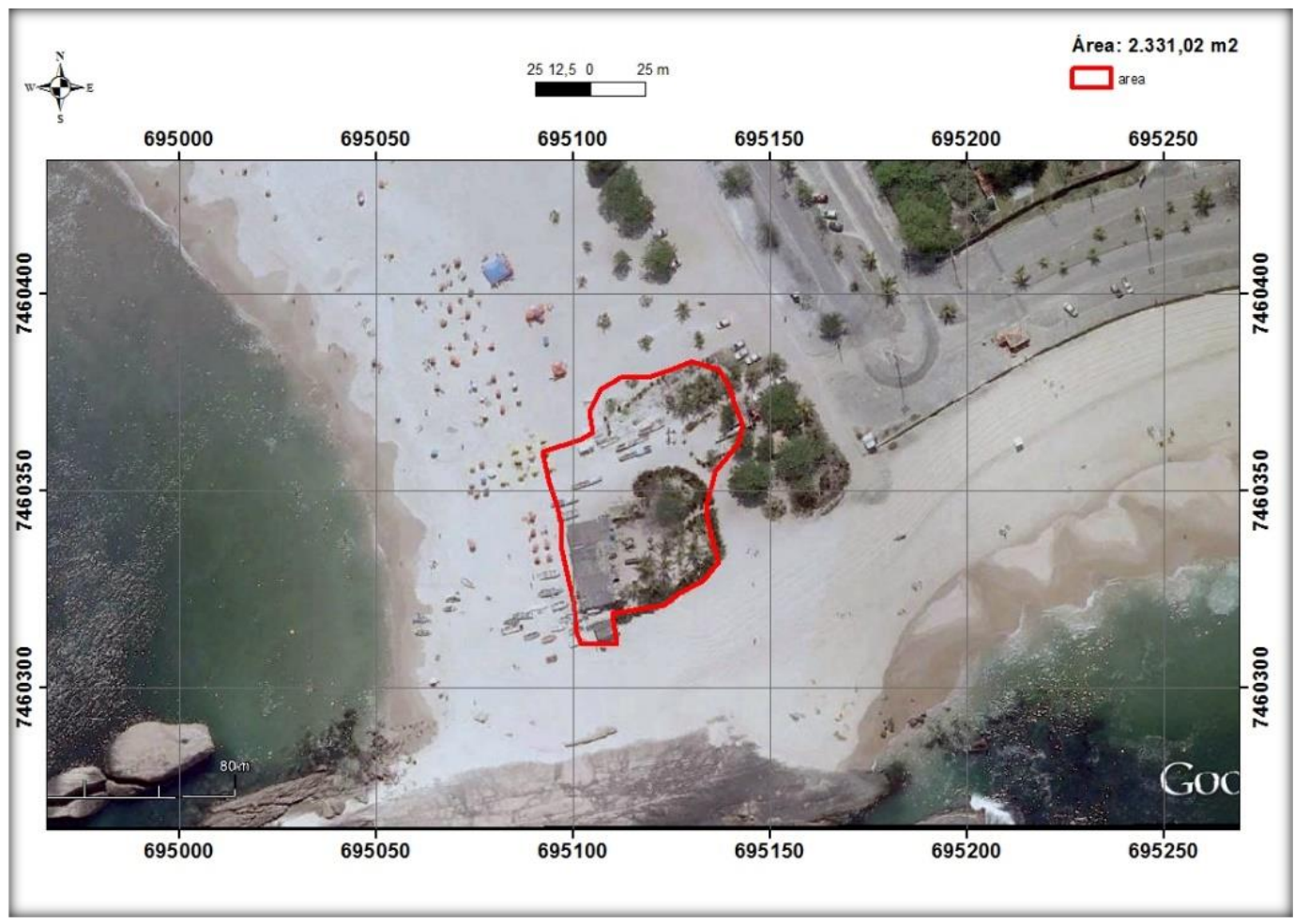

Fonte: Elaborada por Luciana Loto.

Embora a reportagem não tenha informado, aquele havia sido o segundo incêndio. O primeiro, que ocorrera há poucos anos, afetara um quiosque de sapê, localizado na parte externa atrás do barracão. A construção era utilizada temporária e especialmente para que Seu Euclides, um velho pescador aposentado, pudesse reformar uma canoa. Nos dois incêndios, perderam-se embarcações, redes, remos e outros petrechos, além de ter provocado a morte de dois cães que ficavam pelas areias da praia. 
Figura 4 - Seu Euclides reformando uma canoa

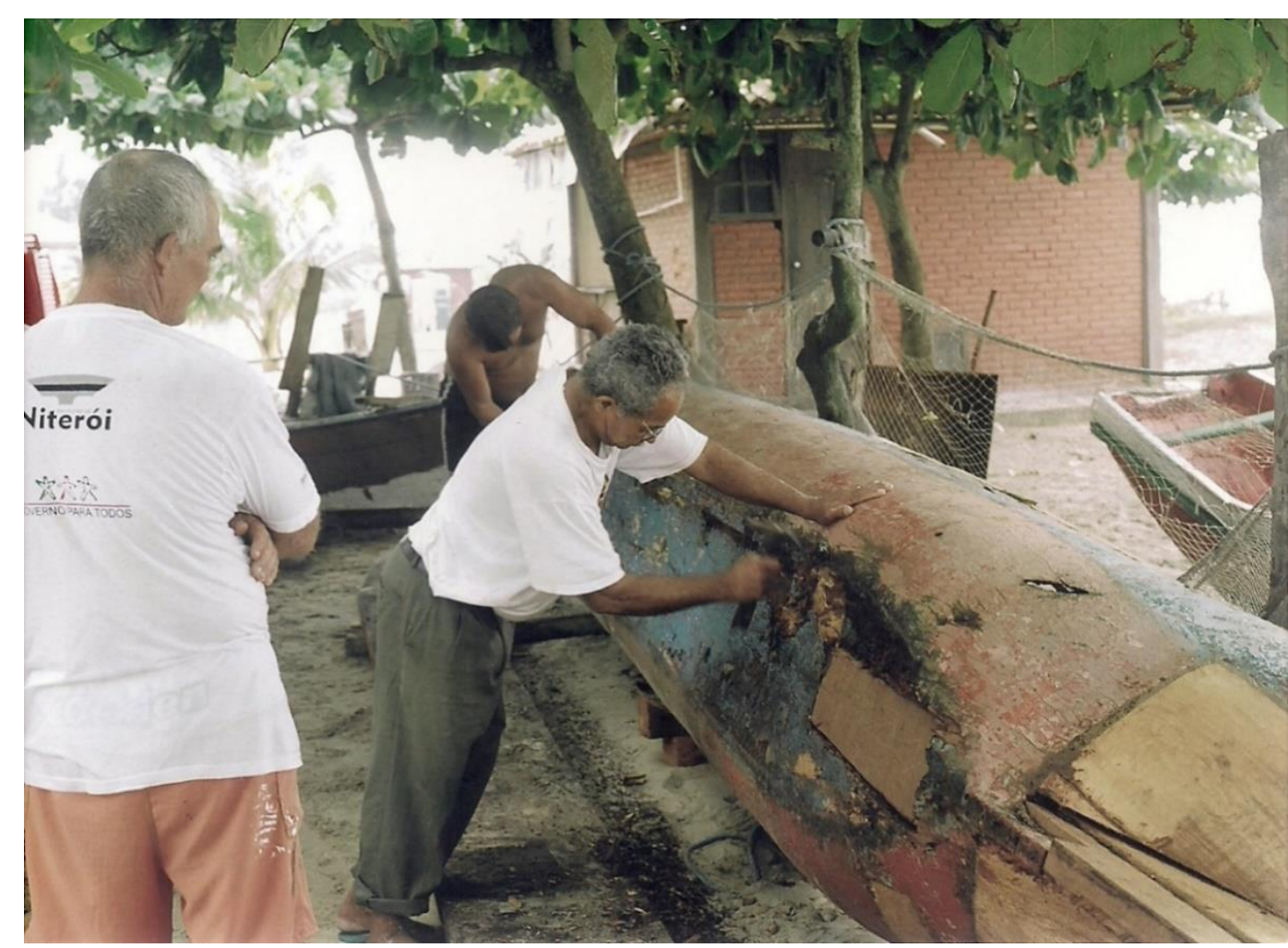

Fonte: Acervo Alpagoa.

Ainda no segundo semestre de 2014, em uma reunião do Conselho Deliberativo da Reserva Extrativista Marinha de Itaipu (Resex-Mar Itaipu), do qual a UFF e a Secretaria de Patrimônio da União (SPU) fazem parte, os representantes dos pescadores de Piratininga levaram várias demandas, como a limpeza do rescaldo do incêndio e apoio aos pescadores afetados. Na ocasião, Ronaldo Lobão sugeriu a utilização do Termo de Autorização de Uso Sustentável (TAUS) como uma forma de regularização do espaço. Esse instrumento está previsto na Portaria $\mathrm{n}^{\circ}$ 89, de 15 de abril de 2010, expedida pela SPU. A servidora Maria Rosa Esteves de Souza, presente na reunião, comprometeu-se a levar a sugestão para o órgão.

Uma das exigências da mencionada portaria, que disciplina o uso e o aproveitamento dos imóveis da União pelas denominadas "comunidades tradicionais", refere-se à elaboração de um "estudo de caracterização". Caso o estudo fosse aprovado, a SPU outorgaria o TAUS, o que permitiria a permanência da comunidade no local. Esse instrumento compreende "as áreas utilizadas tradicionalmente para fins de moradia e uso sustentável dos recursos naturais, contíguas ou não" (artigo $\left.1^{\circ}\right)$, assim como as áreas de "praia marítima" (art. $2^{\circ}$, III). 
A fim de iniciar um estudo de caracterização dos pescadores de Piratininga, uma equipe do Nupij formada por Ronaldo Lobão, Allan Sinclair, Luciana Loto, Matheus Guarino e por mim passou a frequentar a praia. Eis o motivo pelo qual fui aportar naquela paisagem. Eu nasci em Cabo Frio, litoral do estado do Rio de Janeiro e, embora estivesse morando há nove anos em Niterói, havia ido pouquíssimas vezes a Piratininga. Fiquei surpreendido com o lugar, sobretudo com a beleza da pequena enseada que compõe a Prainha.

Figura 5 - Enseada da Prainha vista lateral do barracão

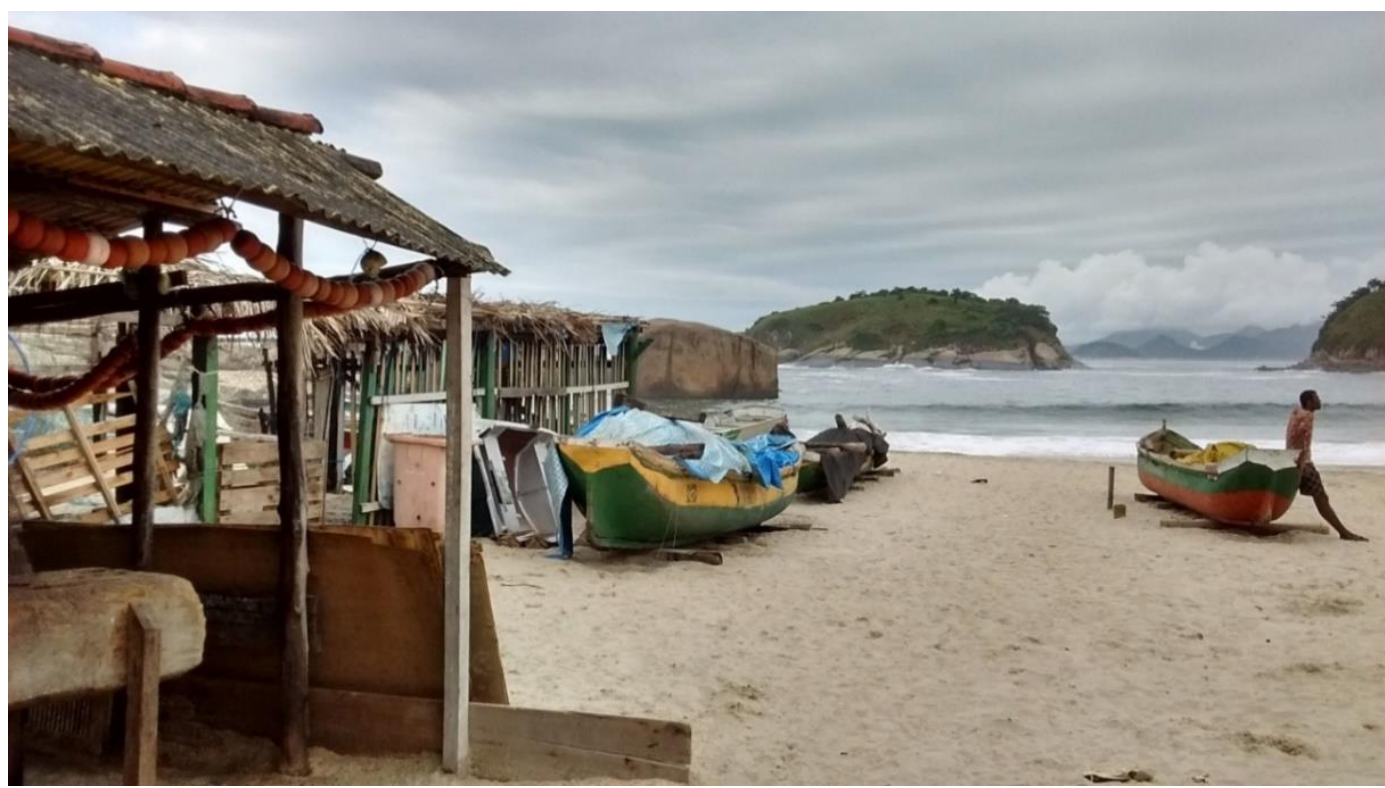

Fonte: Elaborada pelo autor.

Reuníamo-nos com os pescadores aos sábados à tarde - eventualmente, aos domingos -, na parte do barracão que foi menos afetada pelo incêndio. À época, Cléber, um dos pescadores com quem mantínhamos mais contato, disse:

Cléber: A gente conta que venham os órgãos públicos mesmo, ver o que tá acontecendo, quem fez aquilo ali ou por que razão tá feito aquilo ali... "Ah, aquilo ali é uma estupidez, tá em área de Marinha" [referindo-se ao barracão]. Tá em área de Marinha, tem um monte de gente em área de Marinha, não é mesmo? Tá todo mundo em Angra dos Reis com o pé dentro d'água onde o limite do espelho d'água é de 30, 200 metros, não sei quanto. O cara tá com uma mansão ali em Itacoatiara dentro de uma Área de Preservação Ambiental, mas é uma mansão, rola grana. 
Figura 6- Apresentação do estudo de caracterização pelo antropólogo Ronaldo Lobão

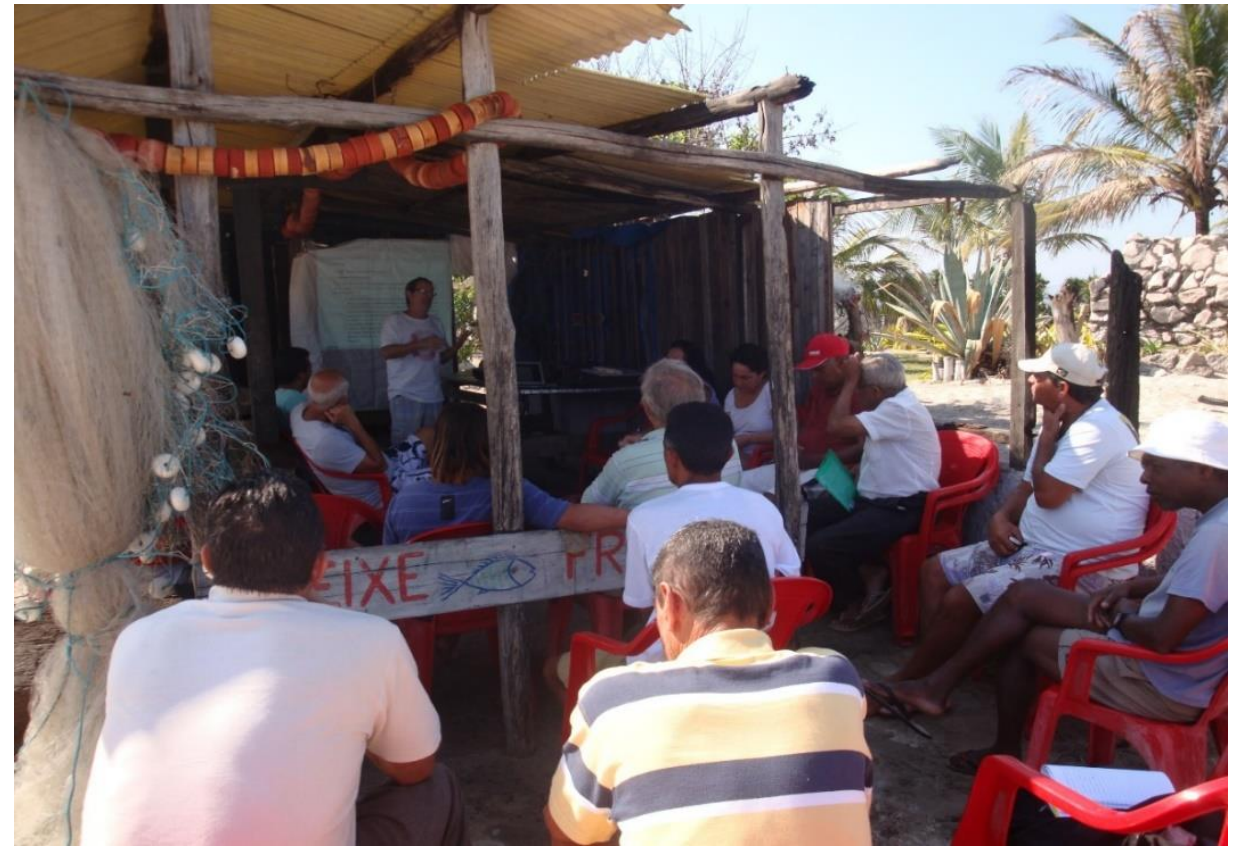

Fonte: Elaborada pelo autor.

Como método, lançamos mão de entrevistas não estruturadas formalmente com entrevistas semiestruturadas. Através de uma adaptação das "rodas" propostas por Luís de Castro Faria, ${ }^{2}$ obtivemos informações a respeito das artes de pesca, dos petrechos utilizados, das espécies capturadas, dos saberes relacionados a prognósticos etc. Os pescadores dividiam-se de acordo com o tipo de pescaria praticada, e cada pesquisador coordenava um grupo. No meu caso, fui responsável pela pesca de linha. Voltamos a campo várias vezes para levantarmos o números de embarcações, os tipos e os tamanhos das redes, bem como para realizarmos a devolutiva do trabalho, através da qual os pescadores poderiam complementar as informações ou apontar possíveis incorreções.

\footnotetext{
${ }^{2}$ Estas rodas eram sugeridas aos seus alunos, e podem ser encontradas em dois trabalhos importantes sobre pesca e pescadores: Kant de Lima; Pereira (1997) e Britto (1999).
} 
Figura 7 - Exemplo de "roda" com os prognósticos de pescarias da Ilha da Marambaia (RJ) ao longo do ano

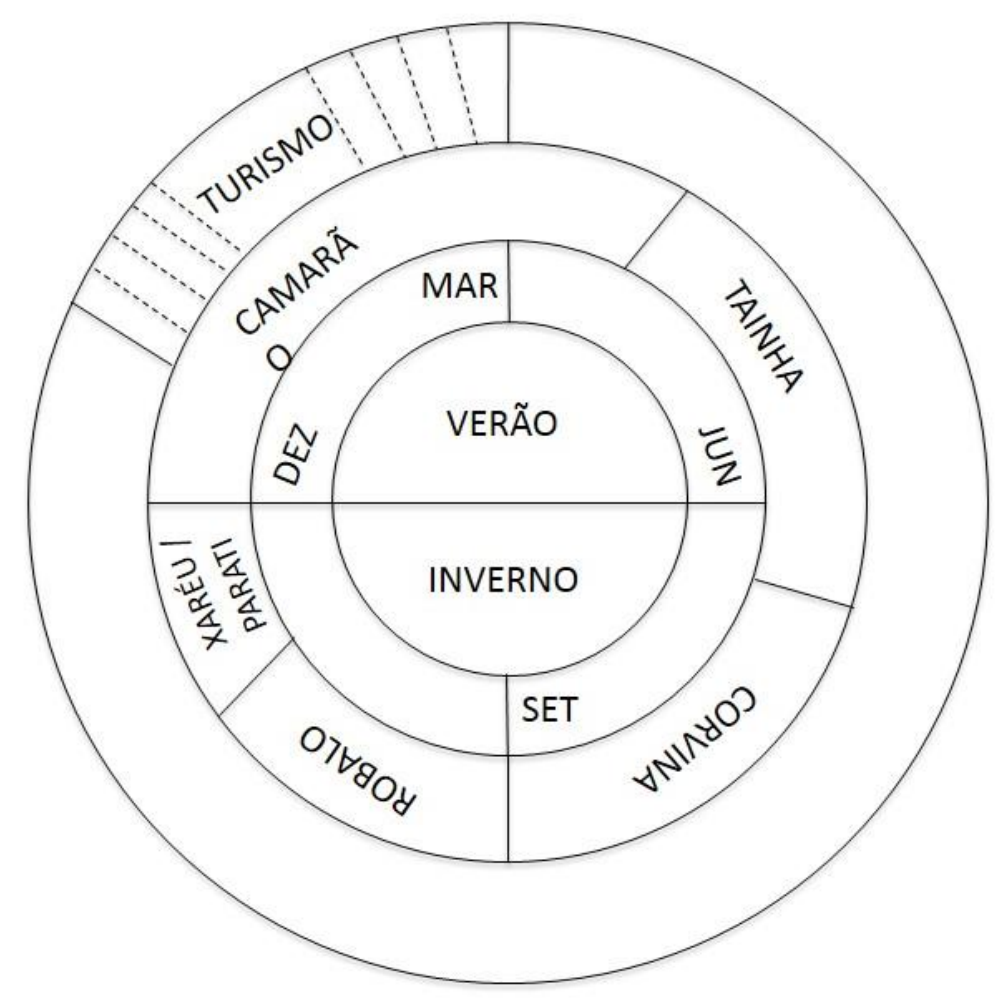

Fonte: ECQ Marambaia, 2016.

Em maio de 2015, encaminhamos o estudo à SPU. Alguns dias depois, o Coordenador de Habitação e Regularização Fundiária do órgão, Alexandre Domingues, nos convidou para uma reunião. Em e-mail enviado à equipe, afirmou que "a regularização fundiária das comunidades tradicionais (pescadores, quilombola, caiçaras e outros...) é uma das linhas de ação que estamos estruturando". Conversamos sobre a possibilidade de se firmar uma parceria entre a SPU e a universidade para trabalhar com essas questões na Praia do Sossego e na Praia de Adão e Eva, ambas em Niterói.

Entretanto, nunca obtivemos uma resposta da SPU a respeito do estudo sobre Piratininga, positiva ou negativa, mesmo através do Conselho da Resex. A parceria, por sua vez, nunca foi realizada.

No mês de agosto do mesmo ano, após quase um ano e tendo ingressado no Programa de Pós-Graduação em Ciências Sociais da PUC-RJ, voltei à praia com o intuito de tentar iniciar minha pesquisa para o mestrado, mas sem a preocupação de formular questões previamente. 
Em minha primeira ida a campo, alguns dos pescadores com quem havíamos entrado em contato no ano anterior me reconheceram. Por um lado, isso facilitou minha entrada; por outro, não sabia até que ponto minha identidade enquanto pesquisador estaria atrelada ao estudo realizado anteriormente. Entretanto, ainda que algumas vezes tenha sido indagado a respeito da posição da SPU, conforme participava mais ativamente no cotidiano do grupo, essa vinculação institucional não se mostrou problemática.

Inicialmente, observava sem muito perguntar; apenas ouvindo. Durante as operações de encalhar e desencalhar (tirar a embarcação do mar e empurrá-la para a areia e colocá-la no mar, respectivamente) voluntariava-me a posicionar os rolos e as estivas, sobre as quais as embarcações são empurradas. O rolo é um tubo oco e aberto feito de policloreto de vinil com aproximadamente $25 \mathrm{~cm}$ de diâmetro. Já as estivas são feitas com tocos de madeira e recebem uma pincelada de sebo, para que a canoa deslize com mais facilidade.

Figura 8 - Operação de encalhar a canoa sobre as estivas.

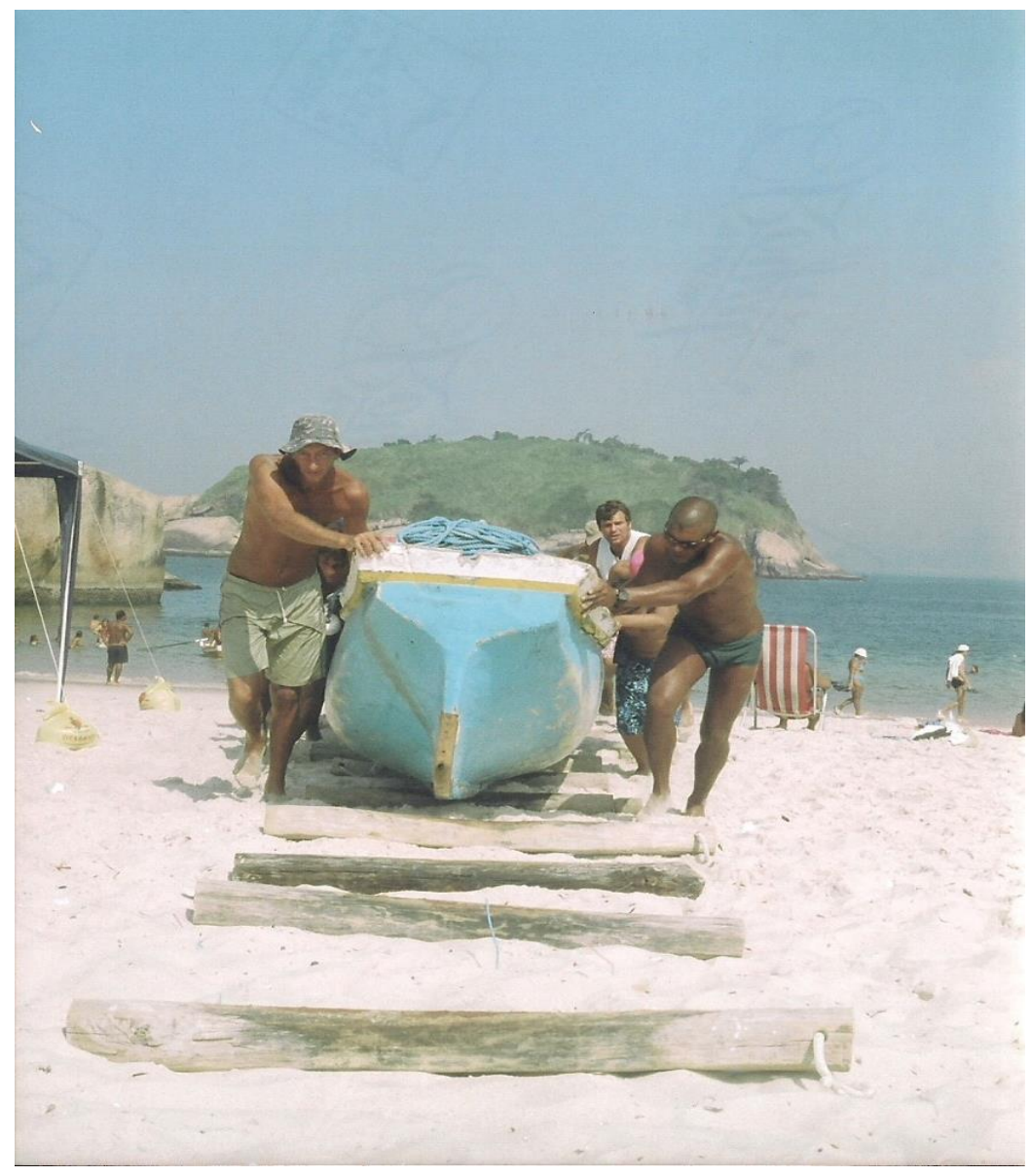

Fonte: Acervo Alpagoa. 
Passei a ir à praia de duas a três vezes por semana. Chegava lá às 7h e saía às $14 \mathrm{~h}$ ou às $17 \mathrm{~h}$. Com o estreitamento dos laços, fui convidado a participar de algumas pescarias, sobretudo nas de canoa, seja pela ausência de pescadores, seja pelo desejo de me mostrarem “o que é ser pescador”, provavelmente ainda motivados pelo estudo de caracterização do qual eu havia participado. Nessas ocasiões, sempre assumi o papel de remador. As posições em uma canoa são delimitadas de acordo com a função exercida por cada pescador, como veremos mais detalhadamente no Capítulo 3.

A participação nas atividades ligadas direta ou indiretamente à pesca possibilitou o acesso a informações e a espaços de socialização geralmente interditos para alguém de fora. Frequentei uma casa na Rua 2, onde moram Kiko, Tia Lucí e Pedrinho, e outra no Tibau, onde mora Seu Vadinho, um pescador aposentado. O Tibau, aliás, é uma importante localidade situada a $900 \mathrm{~m}$ da Prainha e que abriga muitas famílias de pescadores. Com os pescadores, bebi nos quiosques do calçadão em frente à Prainha, nos bares do Tibau, assim como em um aniversário realizado dentro do barracão.

Figura 9 - Aniversário do Lulu no barracão.

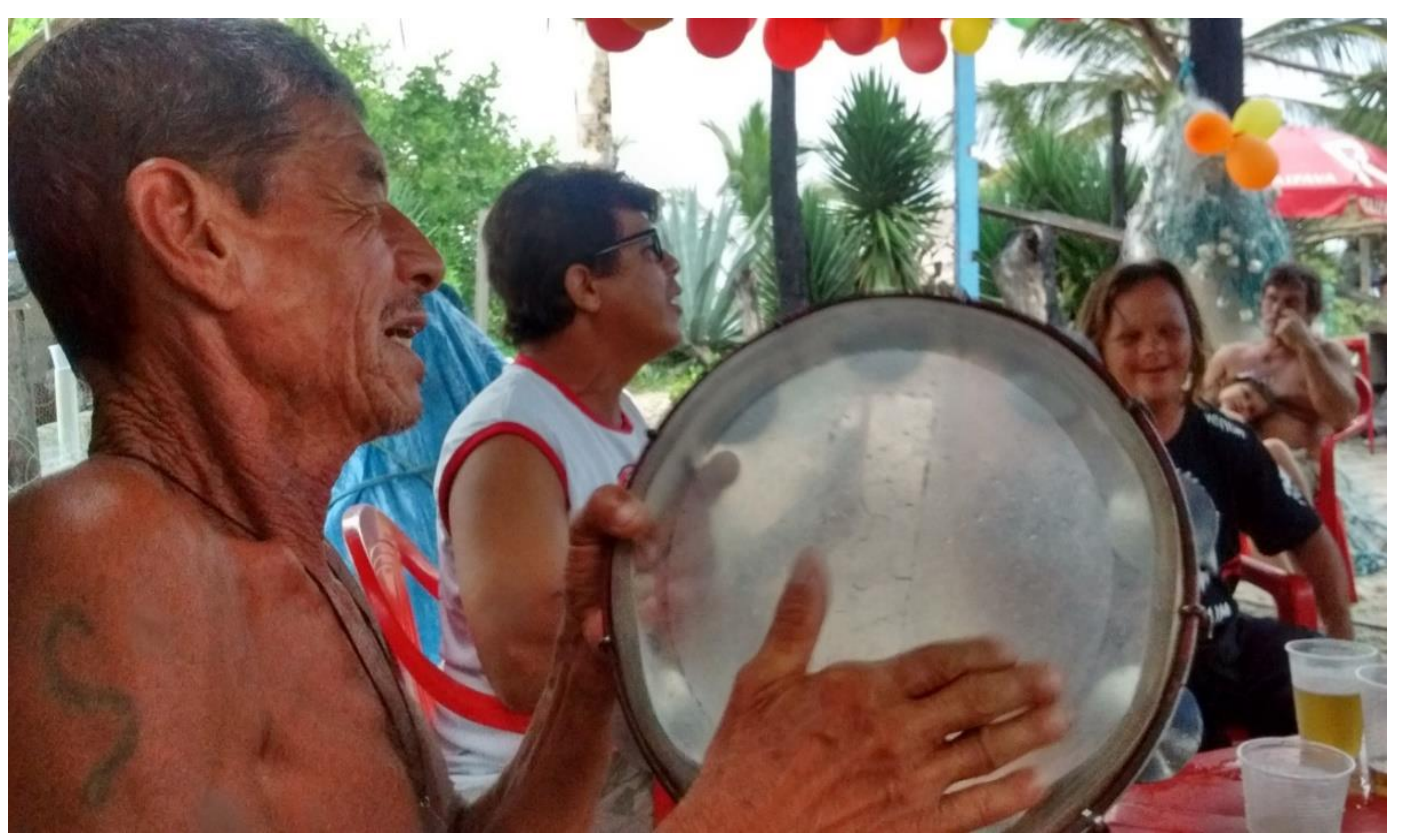

Fonte: Elaborada pelo autor. 
Durante o trabalho de campo, me relacionei com muitos membros do grupo, fossem eles pescadores, familiares ou amigos. No entanto, passei a maior parte do tempo com Cléber, que é o único que ainda exerce o arrasto de praia. Esta arte de pesca é realizada com canoas de um tronco só (feitas de troncos cavados), que medem cerca de $7 \mathrm{~m}$ de comprimento e utilizam apenas remos. Cerca de nove pessoas são necessárias à realização dessa pescaria, que consiste em efetuar um cerco na beira da praia e, em seguida, puxar a rede. Atualmente, pratica-se somente a modalidade do lanço à sorte, na qual não se sabe ao certo quais as espécies que serão capturadas. A extinta modalidade do cerco com vigia contava com a presença do vigia, figura central que, posicionada no alto de uma pedra, determinava onde o cerco deveria ser realizado, as espécies que seriam pescadas e, até mesmo, a quantidade do cardume.

Entretanto, mesmo o lanço à sorte está em declínio frente à expansão da rede de espera, arte de pesca que concentra o maior número de pessoas na atualidade. De manhã cedo, uma ou duas pessoas deixam a rede esticada no fundo, com as extremidades fixadas por âncoras e sinalizada por boias. A rede é recolhida no início do dia seguinte para se tirar a captura. Os petrechos utilizados são comprados em lojas, dispensando o domínio de técnicas de confecção de redes, remos e embarcações próprio das pescarias de arrasto.

Cléber é uma pessoa bastante influente na praia, tendo prestígio na estrutura política do grupo. Um organizador de partidas de futebol recorreu a ele para a construção de um "quiosque" que fizesse sombra para as crianças que jogam bola na ilhota, pequena ilha situada na Lagoa de Piratininga. Quando os guarda-vidas decidiram construir um posto (espécie de bangalô) de onde pudessem avistar banhistas afobados com o mar, comunicaram a ele e perguntaram sua opinião sobre onde a estrutura poderia ser erguida. Foi ele também o responsável pela construção do barracão e pela partilha do espaço, antes e depois do último incêndio. Além disso, ele tem o respeito dos mais velhos - aos quais sempre faz reverências - e é o responsável pela iniciação na pesca de alguns pescadores em atividade.

Isso se deve, em alguma medida, ao fato de ser o único dono e mestre de canoas, pois o arrasto de praia é considerado uma das pescarias mais tradicionais de Piratininga, assim como de Itaipu (KANT DE LIMA; PEREIRA, 1997; MIBIELLI, 2004). Em seu discurso, o signo da tradicionalidade é invocado constantemente: 
Cléber: Eu tô com a canoa para manter a tradição; não se escorraça os velhos. Tem que aprender com eles para não repetir os erros.

Como meu principal centro de referência, a vinculação com esse pescador possibilitou que eu observasse algumas disputas que ocorriam na praia, tendo em vista que, frequentemente, ele era um dos principais contendores. A posição que ele ocupa, portanto, não está isenta de questionamentos e ambiguidades. O objeto das contendas eram os espaços da praia. A despeito do clima amigável e do cenário paradisíaco, nem tudo eram flores na Praia de Piratininga.

A primeira disputa de que tomei ciência, anterior à minha chegada, envolvia Cléber e Josi, um pescador que pratica a rede de espera. Após o segundo incêndio, poucos pescadores mobilizaram-se na reconstrução do barracão. Cansado de esperar a iniciativa da prefeitura e dos órgãos competentes, Cléber, auxiliado pelos pescadores Kiko, Pelicano e Raimundo, recolheu as cinzas e os escombros e começou a reerguer o "acampamento", como ele gosta de chamar para se referir ao caráter provisório e adaptativo do barracão. Nesse meio tempo, porém, Josi apropriou-se de uma parte do espaço que anteriormente cabia a mais de oito pescadores. Chamou um "pessoal do Cafubá” para ajudá-lo com a obra. Segundo Kiko, "ninguém nem sabia quem eram aquelas pessoas".

A situação parece ter piorado quando Josi colocou um portão com cadeado e passou a "fazer comércio" na praia, vendendo peixes e batatas-fritas, cervejas e refrigerantes. Em resposta àqueles que discordavam dessa atividade, argumentava que Cléber também utilizava o espaço com a mesma finalidade, já que Rosa, sua esposa, administrava uma cantina (ou bar/restaurante, segundo os discordantes) no espaço do qual se apropriou. Aliás, era o espaço de maior dimensão, o que era justificado por Cléber pelo fato de possuir grandes embarcações (as canoas) e porque foi ele quem construiu o barracão.

“É tudo comércio!", diziam os pescadores que ficaram de fora da ocupação. Desgostosos, alguns reclamavam mais ("isso agora virou garagem de carro"; "tá parecendo uma favela"), outros tentavam demonstrar indiferença ("não quero nem saber dessa guerra"). Mas todos estavam envolvidos na disputa direta ou indiretamente, seja através das alianças feitas com um dos dois contendores, seja pela insatisfação demonstrada, principalmente em momentos de embriaguez. Havia uma tensão permanente, que ficou clara nas conversas de bastidores, nos 
comentários sussurrados e na disposição das embarcações na areia, mais ou menos próximas das respectivas partes do barracão às quais estavam filiados. Além disso, as representações construídas pelos pescadores sobre si mesmos são quase sempre negativas: "Aqui não tem pescador"; "não tem mais peixe"; "não tem união"; "só tem conflito".

Mas, a despeito das formas particularizadas de apropriação, nunca ouvi ninguém falar "meu barracão" ou "o barracão do Fulano". Referem-se sempre ao barracão como uma unidade indivisível, apesar de ser segmentado.

Figura 10 - Reconfiguração do barracão (vista da Ponta da Galheta).

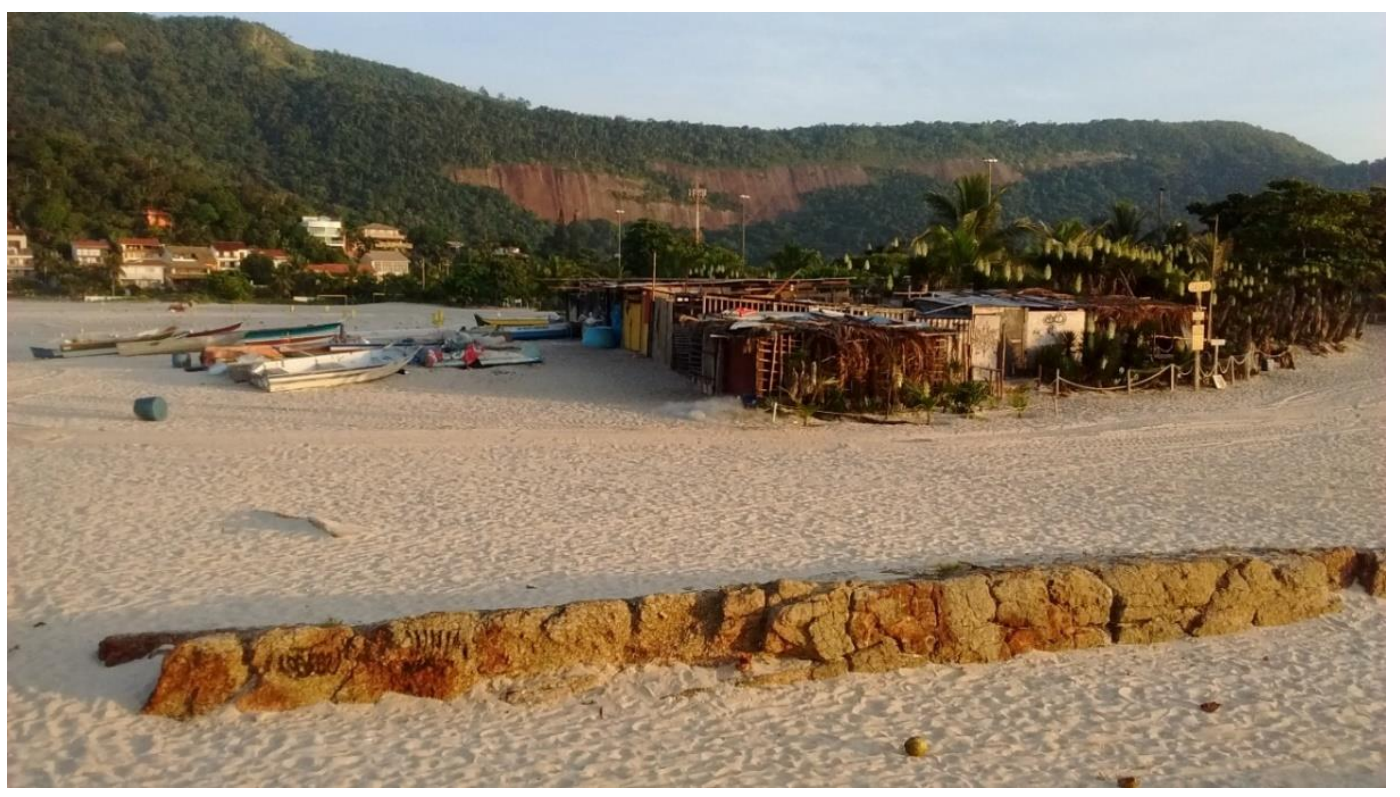

Fonte: Elaborada pelo autor.

A segunda disputa, cuja deflagração pude acompanhar, envolveu Cléber e os barraqueiros que passaram a chegar à praia com vistas à aproximação do verão; especialmente um homem conhecido como Flavão. Infelizmente, não tive muitas oportunidades de conversar com essas pessoas, de modo que as minhas impressões sobre os barraqueiros foram construídas a partir do universo dos pescadores.

Entende-se por barraqueiro homens e mulheres que dispõem mesas, cadeiras e barracas nas areias da praia, com a finalidade de atender aos banhistas (moradores de Piratininga ou turistas, isto é, pessoas que vêm de outras localidades) que chegam à praia nos fins de semana, feriados, período de férias e, sobretudo, durante a estação mais quente do ano, o verão. Vendem peixes e batatas-fritas, água, refrigerante e cerveja. 
Como na disputa anterior, o objeto também era o espaço. Após o incêndio, a área onde se encontra o barracão foi reconfigurada não somente pela nova demarcação como por novas construções que lhe foram anexadas. À direita de quem observa da beira da praia, próxima à Ponta da Galheta, ${ }^{3}$ nota-se a existência de inúmeros barracos nas partes frontal e lateral. Esses espaços foram ocupados por barraqueiros e guarda-vidas, o que trouxe mais animosidade para a praia. As canoas e os barcos, durante o verão, engalfinham-se nas areias com mesas, cadeiras e guarda-sóis, o que dificulta o deslocamento das embarcações e, consequentemente, a realização das pescarias. Há, ainda, relatos de brigas internas entre os próprios barraqueiros.

Figura 11 - Lateral do barracão próxima à Ponta da Galheta.

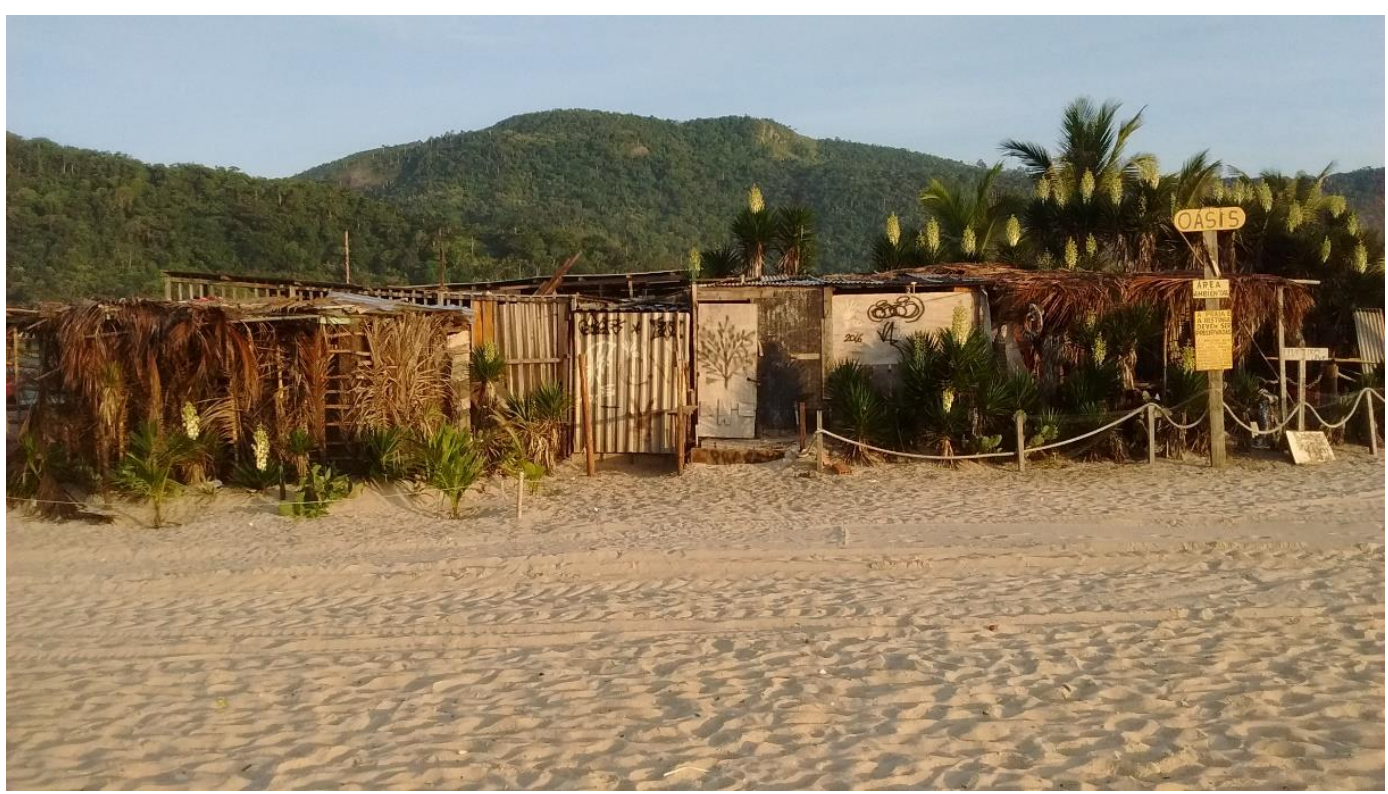

Fonte: Elaborada pelo autor.

Geralmente, os barraqueiros são moradores de Piratininga, mantendo, em alguns casos, vínculos de parentesco e/ou vizinhança com pescadores. Todavia, mesmo sendo considerados como "conhecidos", "parentes" ou "vizinhos", são classificados como "de fora". Isso porque de fora não se refere apenas àqueles que não pertencem a Piratininga, mas também àqueles que não são pescadores (como os compradores habituais do pescado) ou que se encontram em disputa com os pescadores (como os barraqueiros).

\footnotetext{
${ }^{3}$ Formação rochosa que divide a Prainha do Praião.
} 
Nesse caso, vale ressaltar que turma e pessoal são as expressões mais utilizadas pelos pescadores de Piratininga para se referir àqueles que são de fora. Acompanhadas de uma localidade (Jurujuba, Cafubá, favela etc.) e pronunciadas em situações de oposição em relação a normas e comportamentos locais, adquirem uma conotação negativa ( "A turma da Jurujuba vem, raspa o marisco e a pedra fica lisa. Aí, o peixe vai abandonando, não tem o que comer”).

No entanto, a categoria fica mais confusa quando analisamos as trajetórias dos pescadores, pois nem todos são “de” Piratininga. Kiko, por exemplo, com quem construí laços de amizade, é de Várzea das Moças. ${ }^{4}$ Mudou-se para Itaúna (RJ) quando começou a namorar uma mulher. Nessa cidade, aprendeu a pescar por insistência do cunhado, que estava incomodado com a sua predileção pelo surf. Com o término da relação amorosa, Kiko veio a conhecer Piratininga tempos depois, através de Alexandre, irmão de Nareba, pescador local. Depois de idas e vindas de Várzea das Moças a Piratininga, ficou de vez por ali quando conheceu Tia Lucí, uma simpática senhora que o acolheu em sua residência. A partir daí passou a pescar com Cléber.

O leitor deve ter percebido, portanto, que não se trata de uma dicotomia, pois há muitas relações amistosas com pessoas de fora, inclusive com barraqueiros. Nesses casos, são chamadas de amigos. Em diferentes situações, por exemplo, fui apresentado pelos pescadores como "um amigo": "Esse aqui é o Gabriel, um amigo nosso". Da mesma forma, muitos amigos de diferentes partes do município (do Cafubá, Ititioca, Itaipu etc.) acorrem diariamente para o barracão com o intuito de prosear com os pescadores, como Maia, Tatá e Gugu, três irmãos, moradores da Ititioca, ${ }^{5}$ de quem estive bastante próximo.

A partir do segundo semestre de 2016, passei a frequentar menos a praia, a fim de tentar organizar o material obtido e de iniciar o processo de confecção desta dissertação. O trabalho de campo pode ser dividido, portanto, em três etapas: 1) setembro/novembro de 2014 - época do estudo de caracterização com a equipe do Nupij; 2) agosto/dezembro de 2015 - retorno à praia, sem a elaboração de questões; 3) janeiro/junho de 2016 - elaboração de questões e início da construção do objeto.

\footnotetext{
${ }^{4}$ Várzea das Moças um bairro bimunicipal localizado nos municípios de Niterói e São Gonçalo.

${ }^{5}$ Ititioca é um bairro de Niterói que pertence à região de Pendotiba, e fica próximo aos bairros de Santa Rosa e Viradouro.
} 
Apesar do afastamento e mesmo durante a escrita, fui para Piratininga eventualmente, fosse para dirimir dúvidas que surgiram, fosse para rever os amigos.

A metodologia do meu trabalho de campo teve como alicerce a observação participante, pois acredito na necessidade de se construir vínculos mais estreitos com aqueles com os quais iremos trabalhar. Apesar de árdua, essa estratégia foi bastante frutífera em relação à construção da minha relação com os pescadores.

Em um primeiro momento, não levei meu caderno de campo; achava que as anotações poderiam constrangê-los ou gerar alguma desconfiança. Nesse caso, o bloco de notas do celular foi de grande valia. Anotava no aparelho questões, falas, categorias e situações. Ao chegar em casa, passava minhas anotações para o computador, onde mantive um caderno/diário de campo. Essa tarefa exigia muito da minha memória, pois eu tentava transpor para o caderno os mínimos detalhes. Depois que as relações ficaram mais consolidadas, passei a levar o caderno, mapas e a fazer perguntas mais direcionadas.

Embora não afeito ao celular, tenho que admitir que o aparelho foi bastante útil. Além do bloco de notas, fiz uso de um aplicativo de gravador de voz, com o qual pude obter longas entrevistas sobre os mais variados assuntos, desde a técnica de tingimento das redes as disputas em torno do barracão. Algumas dessas falas aparecerão neste trabalho.

O celular também serviu para fotografar e gravar vídeos. As fotos - de minha autoria ou fornecidas pelos pescadores - serão utilizadas aqui como parte integrante da narrativa construída, de modo que o leitor possa melhor percorrer os caminhos e descaminhos do meu campo; não tenho a pretensão, pois, de apresentar um ensaio de antropologia visual.

Ainda no que diz respeito à fotografia, esta se mostrou como uma importante forma de aproximação. Muitas vezes, fui solicitado para registrar determinados eventos, como uma festa de aniversário ou uma pescaria. Em duas ocasiões, imprimi a foto tirada e entreguei, dias depois, ao pescador que nela aparecia. Apesar de ter entregue em momentos distintos, a reação foi a mesma: dava-lhes a foto na beira da praia, onde descarregavam a embarcação ou limpavam peixes (onde era mais fácil encontrá-los); miravam, sorriam e agradeciam. Minutos depois, 
perguntavam: "Eu tenho aqui meia dúzia de olho de cão. Você quer?". Confuso, eu não sabia se queriam me vender ou me retribuir pelas fotos, ficava constrangido e respondia desajeitadamente: "Infelizmente, não trouxe dinheiro hoje". "Mas quem falou em vender?", retrucavam. Colocavam o pescado em uma sacola e me entregavam. Esse gesto possibilitou que eu conversasse mais vezes com eles, havendo mais confiança entre nós.

$\mathrm{Na}$ segunda vez que voltei à praia, fui convidado pelos pescadores para ir até a ilhota. Eles construiriam o "quiosque" citado acima, a pedido do organizador dos jogos e por iniciativa de Cléber. Disseram-me que ninguém receberia nenhum centavo pela tarefa. Faziam aquilo pelas crianças. O material utilizado foi reaproveitado do barracão: pedaços de madeira e palhas de coqueiro. Pus a mão na massa e os ajudei, o que de alguma forma contribuiu para que confiassem mais em mim. Pediram para eu tirar fotos. Na semana seguinte, levei as fotos impressas; todos ficaram contentes e orgulhosos do trabalho que começou pela manhã e terminou à tardinha.

Figura 12 - Construção do "quiosque" da ilhota.

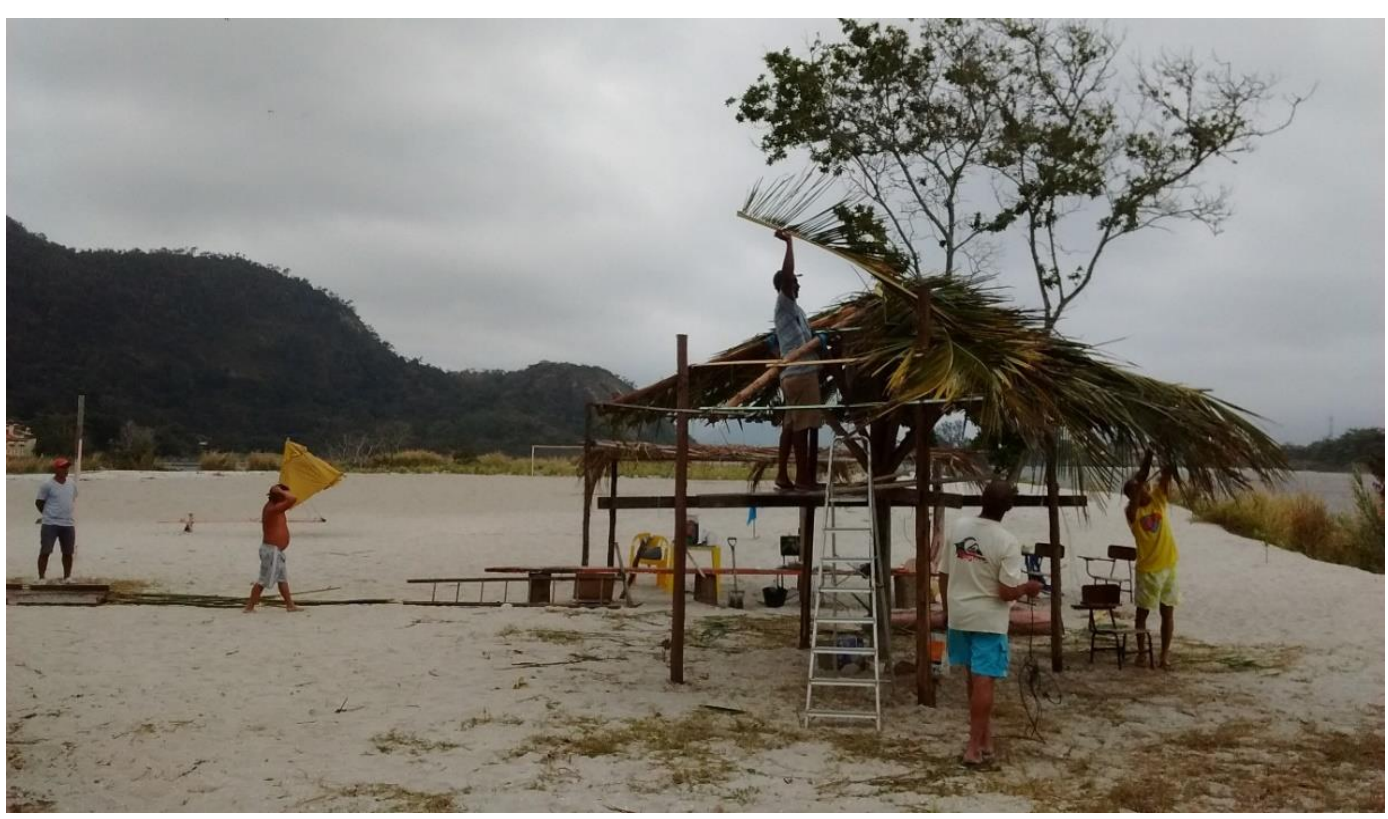

Fonte: Elaborada pelo autor. 


\section{2.}

\section{Conhecendo Piratininga}

O bairro de Piratininga - do tupi, "secagem de peixe" ou "peixe a secar" (PIMENTEL, 2001, p. 27) - é o primeiro da Região Oceânica do município de Niterói (RJ), estando limitado pelas localidades de São Francisco, Jurujuba, Camboinhas, Itaipu, Cafubá e Jacaré. Localiza-se no entorno da lagoa homônima e ao longo de uma praia de $2.700 \mathrm{~m}$ de extensão orientada no sentido leste-oeste.

A Praia de Piratininga é composta por duas partes. O trecho maior é chamado localmente de Praião; o outro, na extremidade norte, chamam-no Prainha, pequena enseada limitada por duas formações rochosas: a maior encontrase à direta de quem aí chega, havendo sobre ela inúmeras casas; à esquerda, vê-se a Ponta da Galheta, próxima à Pedra da Baleia. Da areia pode-se ver a Ilha do Veado, ${ }^{6}$ posicionada à meia distância dessas duas pontas que avançam pelo mar.

Figura 13 - Mapa das praias oceânicas de Niterói.

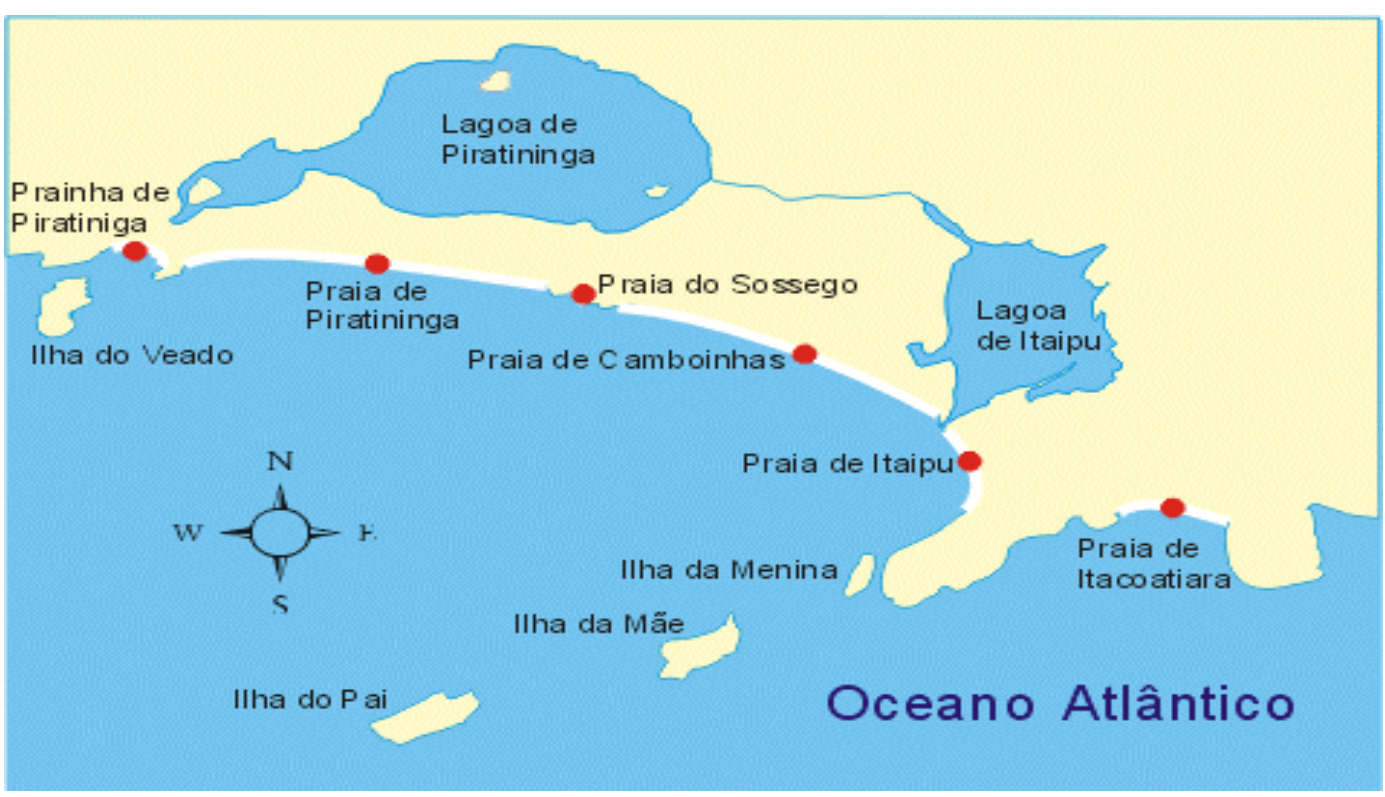

Fonte: Google.

À oeste da Prainha, há o forte D. Pedro II do Imbuí, cuja entrada principal é através do bairro de Jurujuba. Tal fortificação estava atrelada, no século XIX, ao sistema de defesa da entrada da Baía de Guanabara. Mas o seu comando foi extinto

\footnotetext{
${ }^{6}$ Há ali árvores de figueira, cujos galhos assemelham-se aos chifres de um veado.
} 
em 1964. De 1964 a 1992, passou a abrigar grupos de artilharia de costa, responsáveis, ainda, pela guarnição da Fortaleza de Santa Cruz da Barra e pelo Forte Barão do Rio Branco.

Para entendermos melhor a dinâmica atual de Piratininga, creio que valha a pena percorrermos alguns capítulos de sua história, principalmente as páginas sobre a morfologia espacial.

O início do primeiro núcleo de ocupação lusitana nas terras que posteriormente integrariam a cidade de Niterói vincula-se à conquista do Rio de Janeiro pelos portugueses. A aliança bem-sucedida entre estes e os índios temiminós resultou na expulsão dos franceses e de seus aliados da tribo dos tamoios, em 1567, após inúmeras disputas territoriais. No ano seguinte, como retribuição aos serviços prestados à Coroa, os portugueses doaram parte das terras Bandas d'Além aos índios da tribo temiminó, ou seja, terras situadas no lado oposto da Baía de Guanabara (CAMPOS, 2004, p. 136-137).

Nesse período, outras pessoas foram agraciadas com pedaços de terra. Por volta de 1565, coube a Cristóvão Monteiro, por exemplo, companheiro de Estácio de Sá, uma sesmaria em Piratininga, com 400 braças ao longo da costa por 600 para o interior, compartilhada com seu genro, o italiano José Adorno (WEHRS, 1984, p. 36; CAMPOS, 2004, p. 137).

Em 1819, Niterói chamava-se Vila Real da Praia Grande. Posteriormente, em 1835, quando de sua elevação à capital da Província do Rio de Janeiro, adquiriu a categoria de cidade e passou a ser chamada de Nictheroy - ou Nitheroy (WEHRS, 1984, p. 68). Este topônimo tupi significa “água escondida” e sua utilização remetenos ao porto da cidade do Rio de Janeiro por volta de 1554, atual Baía de Guanabara (PIMENTEL, 2001, p. 25).

No ano de 1835, as povoações de São Gonçalo, Nossa Senhora da Conceição de Cordeiros e São Sebastião de Itaipu foram elevadas à categoria de freguesias e anexadas à Niterói. Em 1889, porém, o quadro era outro. Sob a influência da propaganda republicana, o médico piauiense Francisco Portela, ao governar o Rio de Janeiro, tentou implementar a descentralização do poder no estado. Uma das iniciativas consistiu na criação de novos municípios, a exemplo do que ocorreu com São Gonçalo, em 1890 (Decreto n 124). Isso representou um duro golpe para Niterói, pois as freguesias de Itaipu, S. Gonçalo e Cordeiros passaram para o novo município, o que significou a perda das melhores áreas da zona rural. 
A área de Niterói foi reduzida de 245,42 $\mathrm{km}^{2}$ para cerca de $84 \mathrm{~km}^{2}$ (WEHRS, 1984, p. 81).

O município de São Gonçalo foi extinto em maio de 1892, e Niterói recebeu de volta as três freguesias. Todavia, essa demarcação durou pouquíssimo tempo. Em dezembro do mesmo ano, o então presidente do estado, José Tomás da Porciúncula, reestabeleceu o noviço município. Com isso, Itaipu somente seria reincorporada à cidade de Niterói em 1943 (WEHRS, 1984, p. 81-82).

A Freguesia de São Sebastião de Itaipu estendia-se desde Piratininga, Itaipu e Itaipuaçu, junto ao litoral, até locais mais para o interior, onde então começavam as fazendas de Engenho do Mato, Rio do Ouro, Engenho do Roçado, Paciência, Terra Nova etc. No final do século XVIII, localizavam-se na região diversos engenhos, chácaras, olarias e fazendas voltadas para o cultivo de cana de açúcar, mandioca, milho, arroz, feijão, dentre outros gêneros alimentícios. Além disso, “existiam também 45 outras propriedades de menor porte, voltada para a lavoura, sendo quatro delas próximas ao litoral" (PESSANHA, 2003, p. 22).

Com destino à cidade do Rio de Janeiro, a produção da Fazenda do Arrozal, da Fazenda do Saco (pertencentes aos padres jesuítas) e da Fazenda de Piratininga (pertencente a Manuel de Frias e Vasconcelos) seguia, por terra ou mar, até a enseada de Jurujuba. Na segunda metade do século XX, a Fazenda de Piratininga destacava-se pelo cultivo de café e pela produção de aguardente.

Por outro lado, a atividade pesqueira nessa região é bastante longeva. Há relatos a respeito da abundância e da grande variedade de peixes capturados nas lagoas de Itaipu e Piratininga, no interior da Baía de Guanabara, nas enseadas de Jurujuba, São Francisco, São Lourenço, Itacca etc. (WEHRS, 1984, p. 41). Nas palavras de Pessanha (2003, p. 22), “a pesca era, portanto, uma atividade econômica de relativa importância na freguesia, como atestam a presença de vários proprietários e arrendatários entre o mar e a lagoa e a ação de dois agentes da Capitania do Porto no local".

No passado, quando a lagoa estava acima do nível do mar e pouco salobra, enchia-se com o acúmulo das águas das chuvas e dos ribeiros, inundando os terrenos dos habitantes locais e quase penetrando nos "barracões dos pescadores". Estes, então, "sangravam" a lagoa, conforme a descrição feita por Lejeune P. H. de Oliveira, em seu Estudo hidrobiológico das Lagôas de Piratininga e Itaipú: 
No lido próximo à Ponta da Galheta, de praia de areia finíssima e branca, os pescadores cavam um canal à enxada e pá. O próprio pêso da água ajuda abrir o canal que se alarga. Quando o mar está pouco violento leva 8 dias a que Piratininga se esvazie; o sangradouro estando mais estreito e o mar mais violento, esta operação leva 15 a 20 dias (OLIVEIRA, 1948, p. 680-681).

Essa operação, denominada de abertura da barra, estava alicerçada no saber local do grupo de pesca e era um dos fatores mais importantes para a regulação do ciclo biológico da laguna. Isso porque permitia que houvesse a migração em massa de certos peixes da lagoa para o mar. Realizava-se na Prainha, ${ }^{7}$ junto à extremidade direita, a fim de que a ilha não oferecesse resistência à água que vinha da lagoa (SILVA, 1989, p. 11).

À época de sua pesquisa, na década de 1940, Lejeune P. H. de Oliveira relatou que os pescadores lhe diziam "que o peixe já um pouco crescido não pode resistir à tentação da 'catinga da maresia"”, tendo em vista que, enquanto a lagoa ficava quente e com oxigênio escasso na fase de estagnação, a água do mar era mais fresca e mais arejada que a água da lagoa:

Os peixes que vão fazer o seu corso, como por exemplo a tainha, procuram àvidamente sair deste ambiente "abafado" da laguna. Os pescadores então viram que a tainha já sentiu a "catinga da maresia". Nesta ocasião fazer o cerco do peixe que vai para o mar. Quando o tempo é mais violento e a tarrafa não pode aguentar, fazem a pesca a pau (OLIVEIRA, 1948, p. 706).

Na década de 1940, devido ao crescimento da cidade, as regiões litorâneas passaram a ser afetadas por políticas de expansão urbana. É desse período o primeiro plano de urbanização de Niterói, sob a administração do então prefeito Brandão Júnior. Em 1944, encaminhou-se um ofício ao governo do estado através do qual era apresentado “o 'Plano de Urbanização das Regiões Litorâneas de Itaipu e Piratininga', que apesar de não ter sido implementado, estimulou muitas empresas a investir na região" (MACHADO, 2011, p. 38),

Durante a mesma década, o extinto Departamento Nacional de Obras e Saneamento (DNOS) abriu o Canal de Camboatá, interligando as lagoas de Itaipu e Piratininga. A justificativa utilizada para a realização desse empreendimento referia-se à necessidade de se evitar "transbordamentos periódicos sobre as margens das lagunas" (Ibidem, p. 43) e de se conter o surto de malária que havia na região;

\footnotetext{
${ }^{7}$ A operação poderia ser feita concomitantemente nas lagoas de Piratininga e Itaipu ou apenas na de Piratininga, por ser maior e estar em um nível mais alto do que a outra (SILVA, 1989, p. 11).
} 
ambos seriam prejudicais aos projetos urbanísticos vigentes (SARAIVA, 2004, p. $11)$.

Figura 14 - Mapa do Canal do Camboatá.

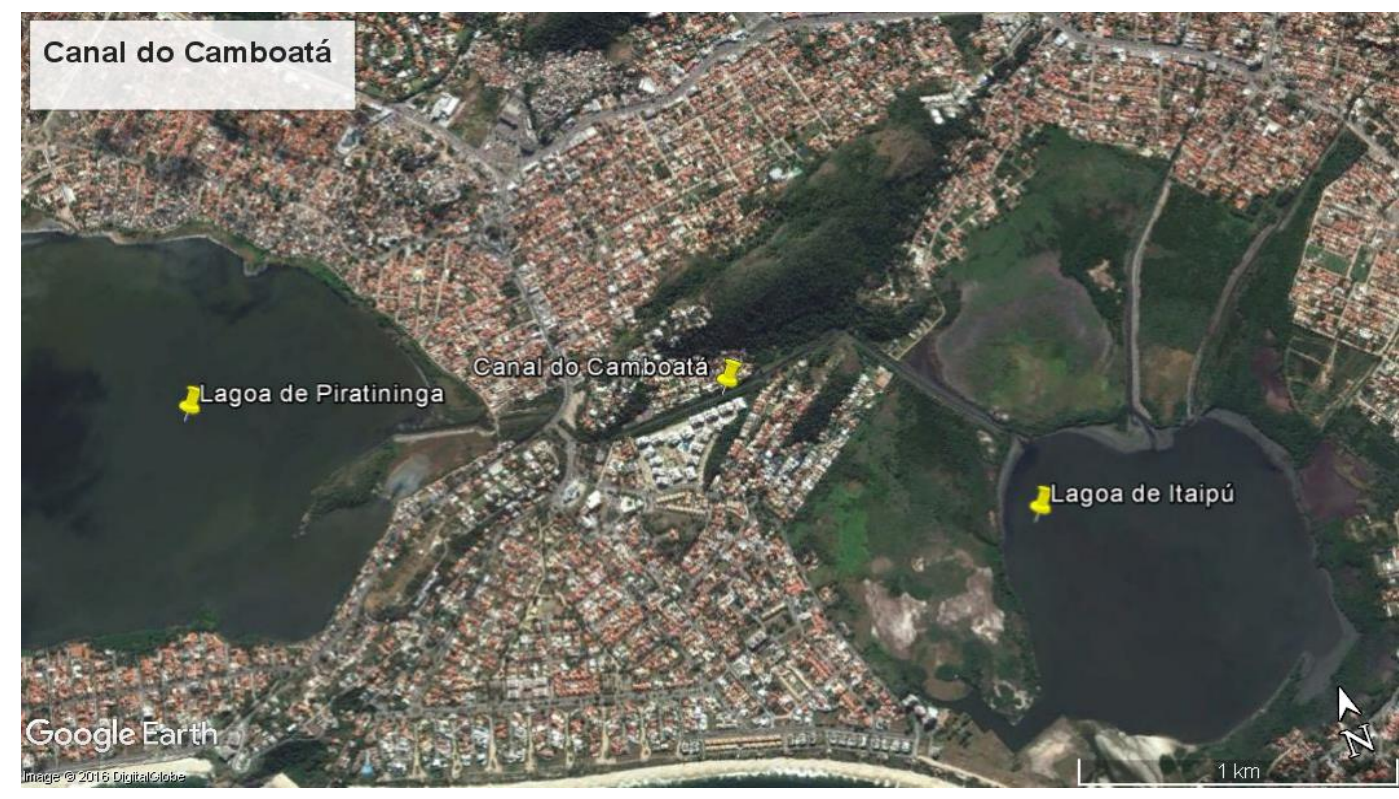

Fonte: Google Earth.

As consequências iniciais de tal intervenção foram observadas in loco por Lejeune P. H. de Oliveira:

\begin{abstract}
A comunicação natural entre as Lagoas de Piratininga e Itaipu foi aberta em vala em 1946. Em outubro de 1947 quase não se podia mais passar de canoa, o capim tinha aterrado grande parte dêste canal. O canal dá passagem a peixes, que os pescadores esperam numa das bocas; a maior quantidade de peixe apanhado foi em dezembro de 1936, cêrca de $1 / 2$ tonelada de tainhas vindas de Itaipu e cercadas de noite na Ponte do Jonjoca (OLIVEIRA, 1948, p. 703).
\end{abstract}

$\mathrm{Na}$ década seguinte, foram aprovados os loteamentos Mar Azul e Bairro Piratininga e ocorreu a pavimentação da Rodovia Amaral Peixoto (RJ-106), um dos principais impulsos para o crescimento da especulação imobiliária na região. A partir daí, foi modificada a composição da população de Piratininga - até então, predominantemente formada por pescadores.

Outra drástica intervenção urbanística ocorreu em 1979, quando a empresa Veplan Imobiliária abriu um canal permanente entre a lagoa de Itaipu e o mar. Isso provocou um grande esvaziamento e, como consequência, reduziu o espelho d'água da lagoa. O efeito para o ecossistema da região foi penoso: o reduzido volume 
d'água de Piratininga não mais permite o rompimento periódico da barra da lagoa feito pelos pescadores, assim como a renovação das águas no seu interior, o que fomentava regulação do ciclo biológico. Além disso, em função do desnível do terreno, a água do mar que entra na Lagoa de Piratininga escoa para a Lagoa de Itaipu e a água que entra nesta não chega àquela. Esse é um dos motivos pelos quais a abertura da barra realizada pelos pescadores não acontece mais.

O Plano Diretor da cidade de Niterói foi criado na década de 1990 (Lei no 1.157/1992), tendo como objetivo direcionar as intervenções urbanísticas e atender às peculiaridades de cada região. Com 55.790 habitantes, ${ }^{8}$ a Região Oceânica possui a maior área do município com $52,42 \mathrm{~km} 2$, tendo sido caracterizada como vetor de crescimento da cidade (MACHADO, 2011, p. 43).

Piratininga é uma das localidades presentes no Projeto Orla Niterói, cujo objetivo é o ordenamento dos espaços litorâneos, especialmente os que estão sob domínio da União. Através de uma aproximação das políticas ambientais e patrimoniais e de uma articulação entre as três esferas de governo e a sociedade, esse instrumento visa solucionar conflitos, mantendo as riquezas naturais, culturais e sociais do litoral brasileiro.

No Dossiê do Projeto (2011), a Praia de Piratininga foi tratada como uma "Unidade de Paisagem", parte integrante de uma macrozona que compreende toda a orla marítima voltada para o Oceano Atlântico. ${ }^{9}$ Essa unidade vai da Prainha até o final da Praia de Piratininga, e é dividida em dois trechos: 1) Prainha (entre a Ponta da Galheta até a Pedra da Baleia); e 2) Praia (da Ponta da Galheta até a Ponta Pé de Boi (Morro da Praia do Sossego). O documento descreve três cenários paisagísticos: atual, tendência e desejado.

\footnotetext{
${ }^{8}$ Não encontrei dados censitários mais recentes.

${ }^{9}$ As unidades dessa macrozona são as seguintes: Unidade I - Praias de controle da União; Unidade II - Praia de Piratininga; Unidade III - Praia do Sossego; Unidade IV - Praia de Camboinhas; Unidade V - Laguna de Piratininga; Unidade VI - Praia de Itaipu -; Unidade VII - Praia de Itacoatiara; Unidade VIII - Laguna de Itaipu.
} 
Figura 15 - Descrição dos cenários paisagísticos da Prainha segundo o Projeto Orla.

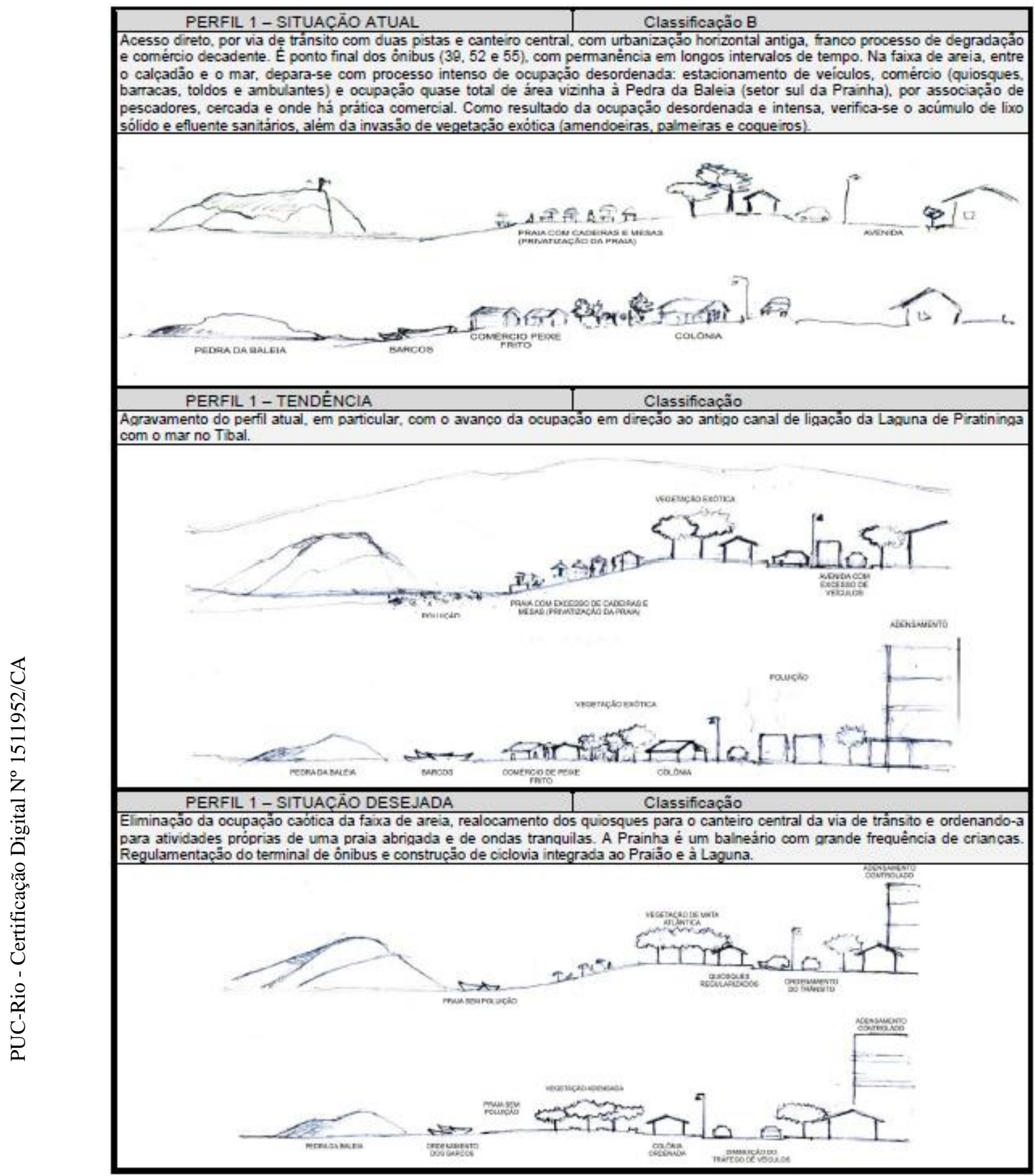

Fonte: PROJETO ORLA, 2011, p. 44.

A descrição do cenário atual, cuja tendência seria o agravamento, refere-se a um "processo intenso de ocupação desordenada" das areias da praia. Além da presença de estacionamento de automóveis e comércio (quiosques, barracas, toldos e ambulantes), cita-se a "ocupação quase total de área vizinha à Pedra da Baleia (setor sul da Prainha), por associação de pescadores, cercada e onde há prática comercial". 
Como forma de ordenar esse espaço, o documento sugere que o estímulo das atividades socioeconômicas da pesca artesanal no local, compatíveis com o "desenvolvimento sustentável" da orla, poderia ocorrer através da "proteção" e "permanência" da área da orla ocupada pelos pescadores. Tal ocupação teria como características: a) os cuidados por parte da comunidade de uma cobertura vegetal nativa, que evite a erosão da restinga; e b) a existência de uma unidade de conservação (Resex-Mar Itaipu), que reconheça a presença de comunidades tradicionais de pescadores que utilizam recursos pesqueiros de forma sustentável.

Em relação à existência de uma unidade de conservação, foi criada, em 2013, a Reserva Extrativista Marinha de Itaipu (Resex-Mar Itaipu), após um longo e tortuoso percurso. ${ }^{10}$ Apesar do nome, essa unidade compreende a área marinha adjacente às praias de Itacoatiara, Itaipu, Camboinhas e Piratininga, bem como a Lagoa de Itaipu (Decreto estadual $n^{\circ} 44.417 / 2013$ ). O processo de criação foi iniciado em 1996, paralelamente à criação da Reserva Extrativista Marinha de Arraial do Cabo, decretada em janeiro de 1997. Muitos atores e instituições estiveram envolvidos, e parece não ter havido consenso a respeito dos significados e da necessidade de se construir uma Resex (LOBÃO, 2010; MIBIELLI, 2014; SICLAIR, 2015). Os pescadores de Piratininga disseram-me que "não eram contra a Resex, mas contra a forma como estava sendo feita"; para eles, faltou transparência.

\footnotetext{
${ }^{10}$ Para uma discussão mais pormenorizada a respeito do processo de criação da Resex Itaipu, ver Lobão (2010), Mibielli (2014) e Sinclair (2015).
} 
Figura 16 - Mapa da situação da Resex Itaipu.

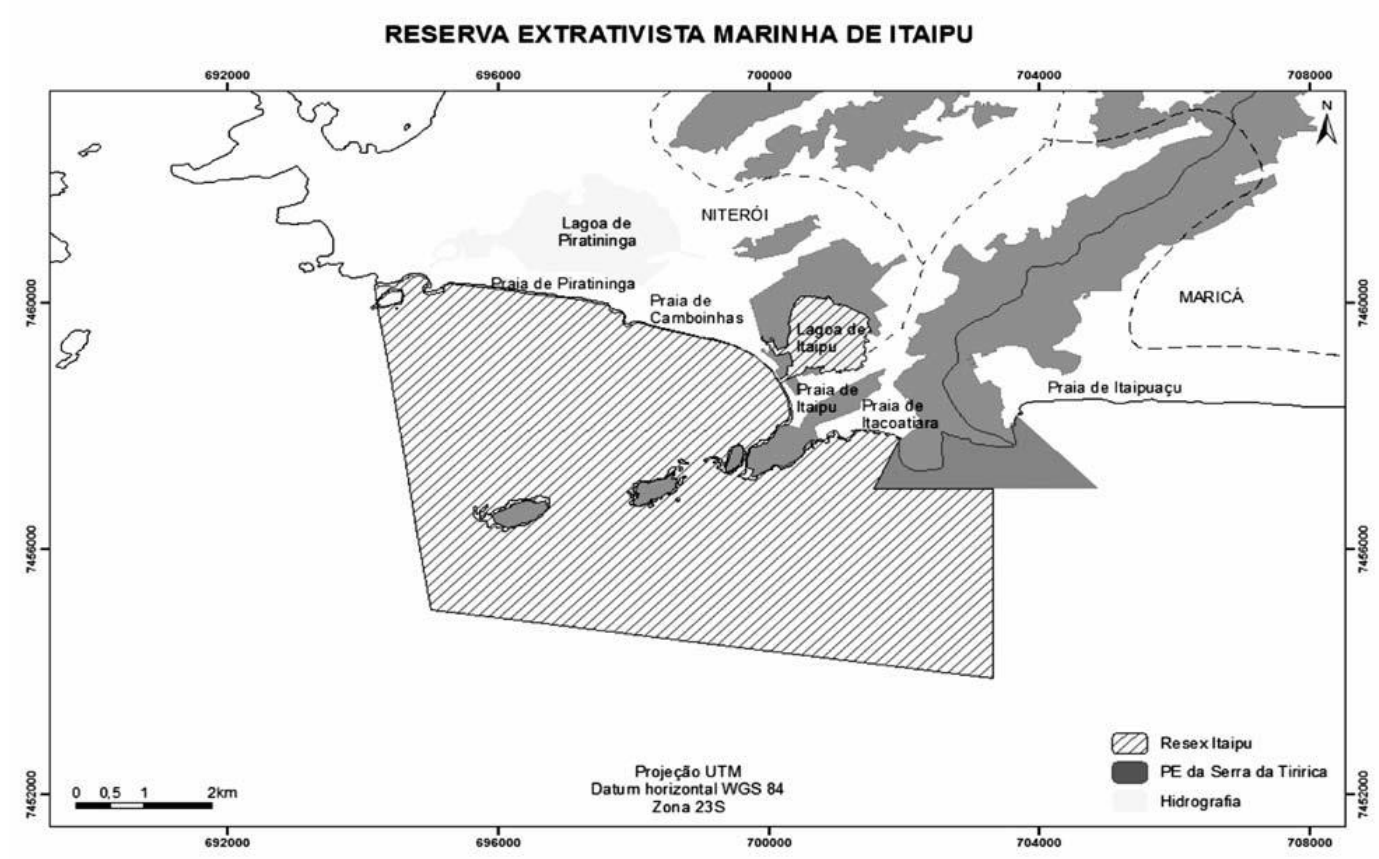

Fonte: Decreto no 44.417/2013.

De acordo com o decreto de criação da Resex, os pescadores de Itaipu e de Piratininga constituem uma "população tradicional", ${ }^{11}$ sendo ambos enquadrados como pescadores que esperam o peixe chegar a seus lugares tradicionais de pescaria. O Ato de Posse do Conselho Deliberativo da Resex (Portaria INEA/DIBAP $n^{\circ}$ 42/2014) ocorreu no dia 12 de abril de 2014. Cinco das vagas disponíveis de pescadores tradicionais foram preenchidas por pescadores de Piratininga, nas modalidades de arrasto de praia, rede de espera, linha, mergulho e tarrafa.

\section{3.}

\section{A localidade do Tibau}

Os pescadores de Piratininga não moram na própria praia, como em Itaipu (KANT DE LIMA; PEREIRA, 1997), tampouco vivem no barracão de pesca, como alguns pescadores de Zacarias, em Maricá (MELLO; VOGEL, 2004). A maioria deles mora em áreas urbanizadas, onde também vivem pessoas que não têm relação com a atividade pesqueira. Uma dessas localidades é o Tibau, habitada por

\footnotetext{
${ }^{11}$ No Capítulo 5, analisarei a construção e as implicações deste conceito.
} 
diferentes gerações de pescadores. Optei por descrevê-la em detrimento de outros pontos de moradia por dois motivos: 1) muitos pescadores com quem estive moram no Tibau (cerca de seis pescadores) e, consequentemente, 2) foi umas das localidades que mais frequentei no decorrer do trabalho de campo.

Figura 17 - Mapa da localidade do Tibau.

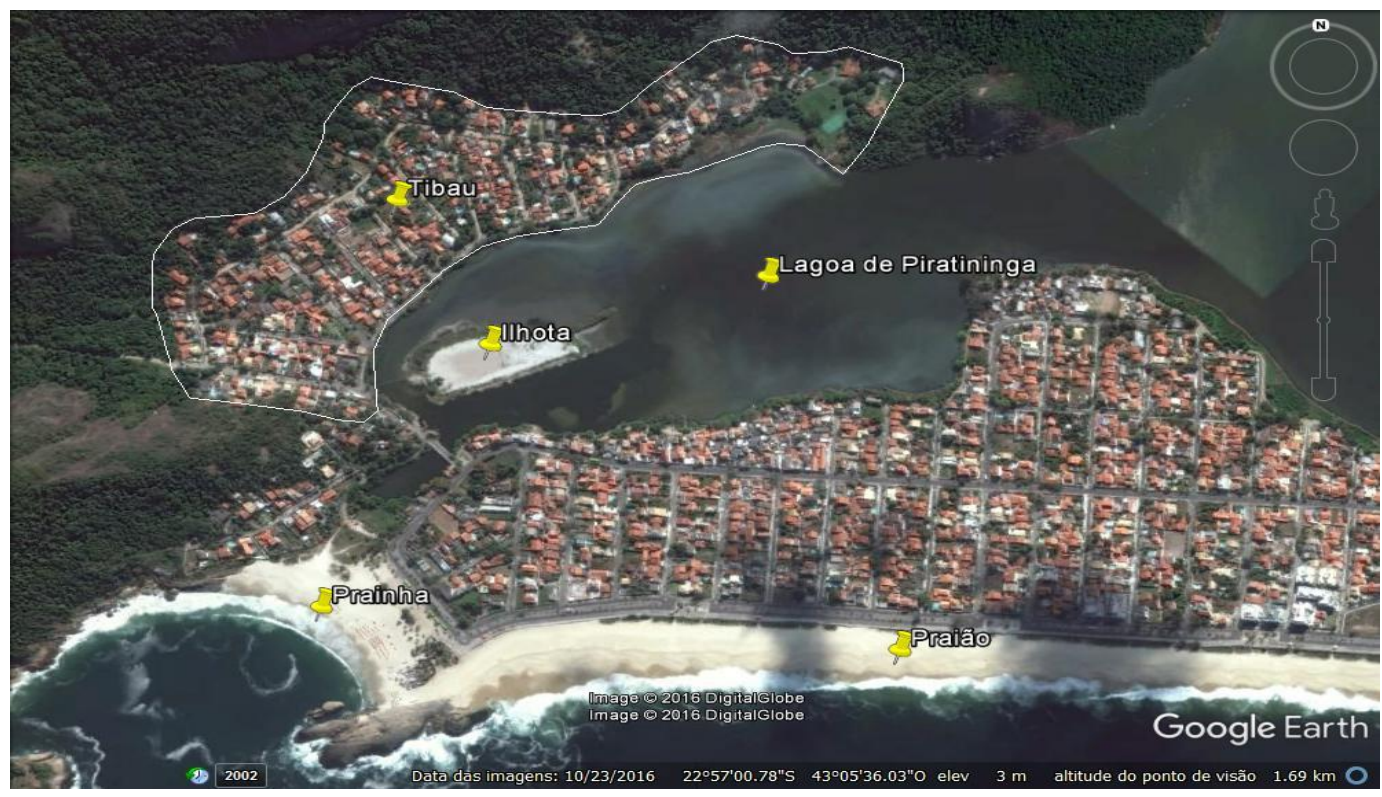

Fonte: Google Earth.

O Tibau fica a $900 \mathrm{~m}$ da Prainha (cerca de 11 minutos a pé), de modo que as relações de vizinhança e parentesco confluem para a praia, assim como a pesca não está restrita ao mar e ao barracão. Os pescadores vão e voltam para suas casas com facilidade. Encontroam-se em bares e mercearias do Tibau ou no barracão de pesca. Como é uma localidade pequena - lembra até uma pequena cidade do interior -, "todo mundo se conhece", "é tudo família", como costumam dizer.

Em alguma medida, essa dinâmica também ocorre com quem mora fora do Tibau em logradouros próximos à praia, como a Rua 2, a Rua 8, a Rua 12 ou a Av. Almirante Tamandaré. Nesse sentido, o controle interno exercido pelo grupo é bastante acentuado, havendo uma rápida circulação de informações, "fofocas" e intrigas.

Chega-se ao Tibau pela praia, através de uma rua situada na área onde se realizava a abertura da barra, ou através de uma ponte, que se inicia no lado direito da Av. Dr. Acúrcio Torres (para quem chega em Piratininga). A ponte foi construída por cima da lagoa, e dela pode-se observar a realização da pesca lagunar. 
Figura 18 - Pescador tarrafeando na lagoa (vista da ponte).

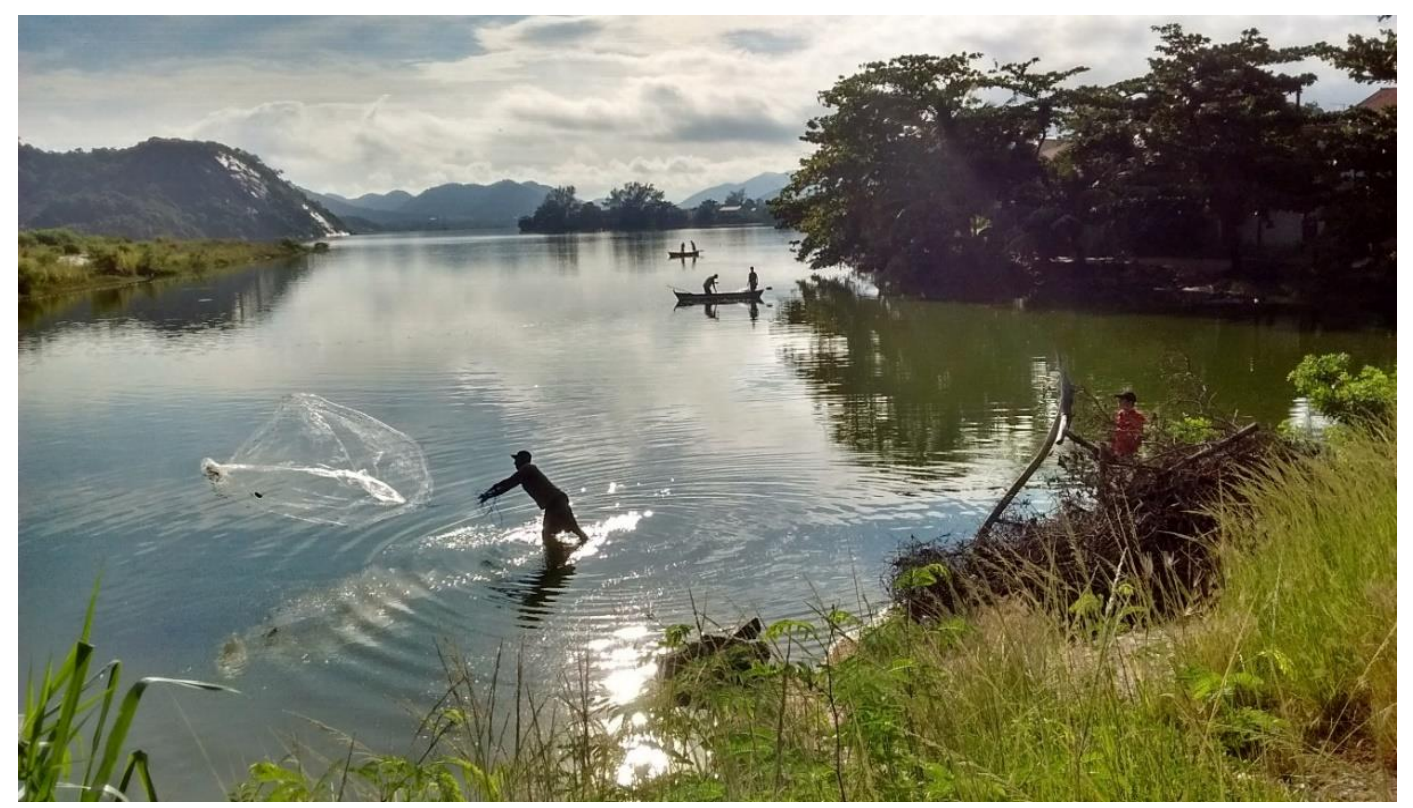

Fonte: Elaborada pelo autor.

O nome desse lugar é uma homenagem ao falecido Tibau, antigo dono de um armazém, onde eram vendidos, dentre outros víveres, os peixes capturados em Piratininga. Naquela época, havia um entreposto de pesca no Imbuí, cujos principais compradores eram Nonô e Tibau, que carregavam o pescado em uma carreta e vendiam para o mercado ("eram os atravessadores da época"). Como eram donos de armazém, também trocavam mercadorias com os pescadores, que lhe levavam ou prometiam peixes.

Cléber: Antigamente [em Piratininga], só tinha pescadores, e eles [Nonô e Tibau] é que forneciam o alimento, que compravam o peixe e o camarão. O camarão era vendido na lata de banha de $2 l$ (medida do camarão), porque nesse tempo não existia plástico.

A localidade é constituída, principalmente, por residências. Mas há bares, restaurantes, algumas vendinhas e uma unidade básica de saúde (UBS Piratininga Dom Luiz Orione). Há, ainda, uma área reservada às Forças Armadas, por onde se chegar ao Forte do Imbuí, assim como o Núcleo Espírita Chico Xavier (entre a Rua das Tainhas e a Rua dos Tatuís), a Capela de Nossa Senhora da Penha (entre a Rua das Gaivotas e a Rua dos Mariscos) e o Centro Umbandista Seara do Caboclo Flexeiro (entre a Rua das Conchas e a Rua das Ostras). 
A maioria dos nomes dos logradouros refere-se a elementos marítimos e à pesca: Av. dos Pescadores, Rua dos Corais, Rua das Ostras, Rua das Conchas, Rua dos Pampos, Rua dos Mariscos, Rua das Gaivotas, Rua dos Golfinhos, Rua das Tainhas etc.

Figura 19 - Conversa no Tibau na beira da lagoa (Kiko e Seu Vadinho).

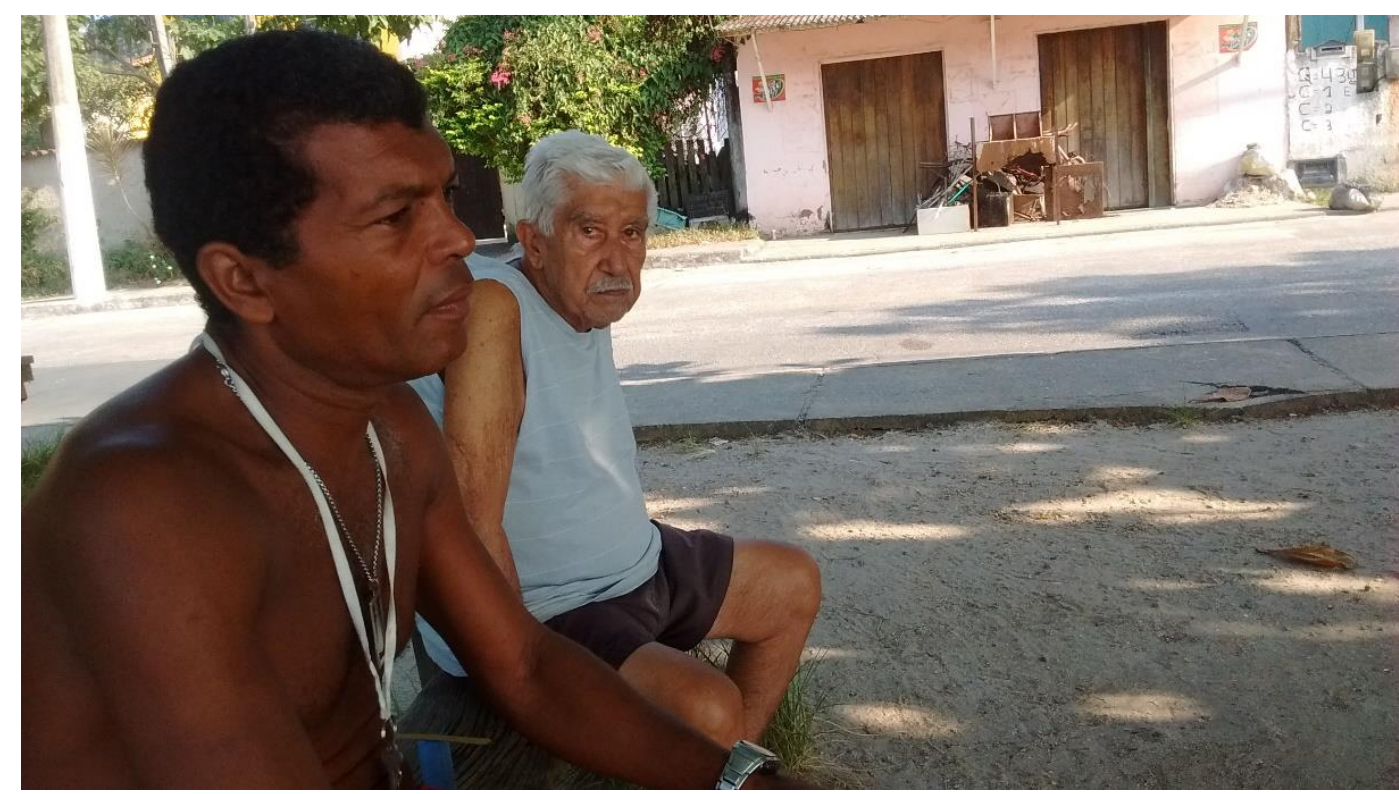

Fonte: Elaborada pelo autor.

No Carnaval de 2016, fui convidado para participar e registrar, em vídeo, os ensaios do Babando na Gola, bloco carnavalesco criado no Tibau e que há anos percorre a Av. dos Pescadores em direção à Av. Acúrcio Torres. O convite partiu de Trico, pescador de rede de espera e que mora na localidade desde criança. Seu pai, Dozinho, era um renomado pescador, bastante referenciado na praia.

O bloco é formado pelos moradores da localidade, do Recanto das Garças ${ }^{12}$ e de outras ruas de Piratininga. Muitos pescadores, como Trico, Valmir, Josi e Celso, são membros da agremiação. Além da execução de sambas famosos, sambas-enredos e marchinhas, o bloco anualmente traz composições próprias. A mais conhecida (tida como "o" hino) é "Piratininga, filha de Iemanjá", sambaenredo composto por Trico e Celso:

\footnotetext{
${ }^{12}$ Outra localidade, situada a cerca de $3 \mathrm{~km}$ da Praia de Piratininga.
} 
Brilhou na serra,

Caiu no mar,

Piratininga é filha de Iemanjá!

Acúrcio Torres, empolgação!

Babando na Gola arrastando a multidão.

É carnaval,

Vamos brincar!

Nesse dia de folia,

Quatro dias sem parar.

Bis

\begin{abstract}
Que emoção!
Que emoção,

Nosso bloco encantando a multidão

Na chegada de um novo milênio

Uma nova era surgirá

E o Brasil vai ver meu bloco desfilar.
\end{abstract}

A possibilidade de participar dessa festividade contribuiu para que eu estreitasse meus laços com os pescadores e estendesse minhas observações para além do espaço do barracão. Durante o evento, notei que as disputas que ocorrem na praia não necessariamente desdobram-se para outros ambientes. Em uma mesma mesa, bebiam e tocavam instrumentos três pescadores que eu equivocadamente acreditava serem opositores. Mas, conforme meus anfitriões disseram-me ao longo daquele dia: "Aqui no Tibau é tudo família". 


\section{3.}

\section{Personagens do drama}

\section{1.}

\section{Pescadores e pescarias}

\subsection{1.}

\section{Socialização na pesca}

Apesar dos discursos pessimistas de alguns pescadores, que asseveram que não há mais pescadores e peixes em Piratininga, observei que a atividade pesqueira continua a concentrar muitas pessoas. Segundo os relatos dos mais velhos, teria havido, inclusive, um aumento substancial do número de pescadores na localidade.

A pesca, em Piratininga, é uma atividade que diz respeito ao universo masculino. Ao contrário do que foi observado na Ilha da Marambaia (MOTA, 2003) ou no litoral de Santa Catarina (GERBER, 2014), por exemplo, as mulheres não participam das pescarias e não são reconhecidas localmente como pescadoras.

Todavia, indiretamente, as mulheres exercem importantes funções nas tarefas relacionadas à pesca. E, nesse sentido, como ressalta Maneschy (2013, p. 41), são juridicamente reconhecidas como pescadoras artesanais, já que a definição de "atividade pesqueira artesanal" passou a incluir, a partir da Lei n ${ }^{\circ} 11.959$, de 29 de junho de $2009,{ }^{13}$ os "trabalhos de confecção e de reparos de artes e petrechos de pesca e o processamento do produto da pesca artesanal", ou seja, as tarefas pré e pós-captura, nas quais há a presença de mulheres.

Em alguns casos, as esposas, parentes ou amigas dos pescadores são as responsáveis pela limpeza, armazenamento e venda do pescado, operações realizadas em casa ou no barracão de pesca. Quando isso ocorre, geralmente houve um excedente de produção, seja pela abundância de peixes capturados, seja pela falta de compradores na beira da praia. Em outros casos, as esposas encarregam-se do controle contábil da pescaria, discriminando, em cadernos ou blocos de anotações, as quantias auferidas com a venda dos peixes, bem como a distribuição

\footnotetext{
${ }^{13}$ Dispõe sobre a Política Nacional de Desenvolvimento Sustentável da Aquicultura e da Pesca.
} 
do quinhão (parte do rendimento obtido com a pesca) para cada companheiro (membro de uma equipe de pescadores).

Figura 20 - Kátia, amiga dos pescadores, ajudando na limpeza do pescado.

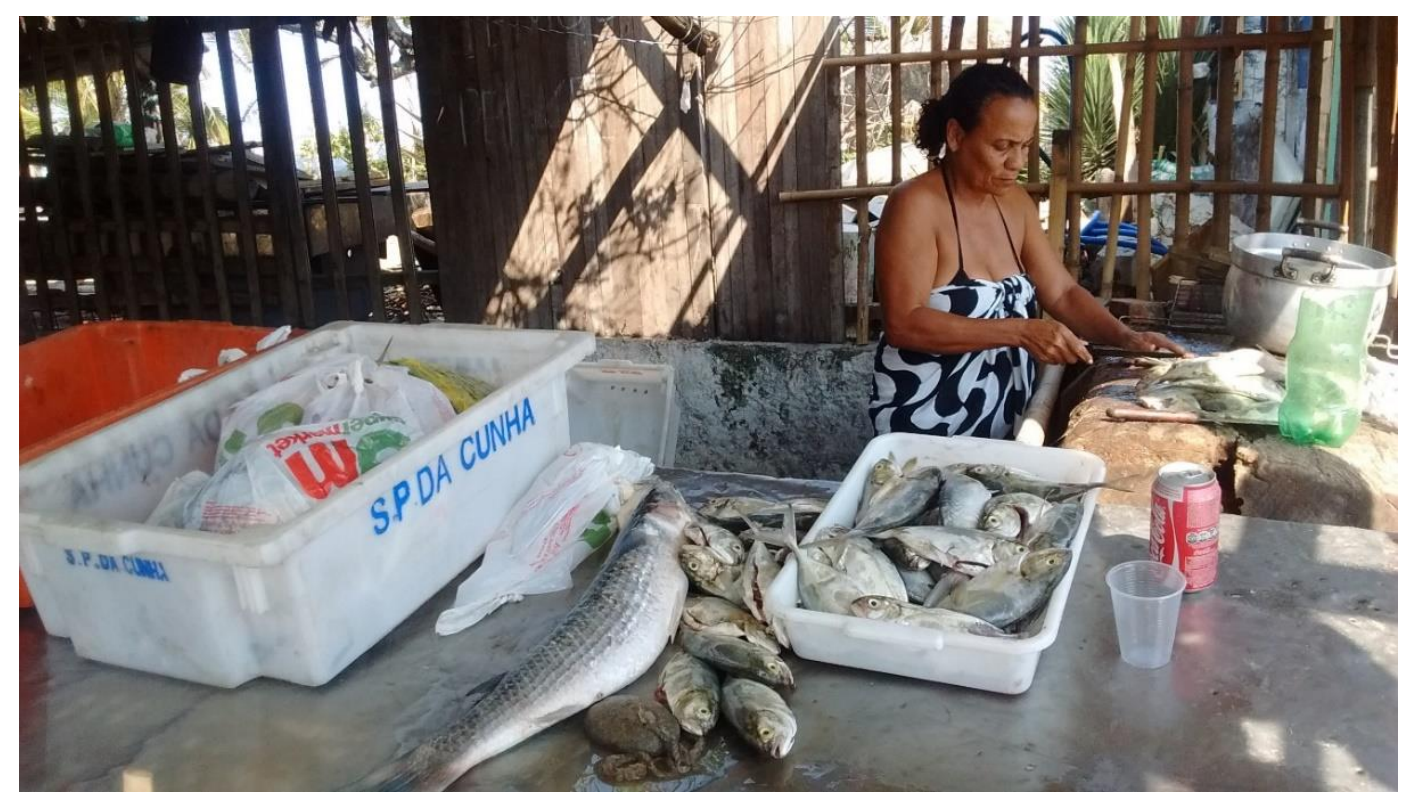

Fonte: Elaborada pelo autor.

No passado, as mulheres participavam da elaboração dos prognósticos da pesca. Na época da tainha, relacionavam a florada da pita (Agave americana) com a chegada dos cardumes, e diziam aos pescadores: “A pita tá florida, vai lá que vai dá tainha". Do mesmo modo, elas eram as responsáveis por tecer, fiar e reparar as redes, que eram feitas em uma roca com os fios do tucum (Bactris setosa), palmeira que cresce formando touceiras densas. Elas também tingiam as redes de arrasto com murici (Byrsonima crassifólia) ou aroeira (Schinus terebinthifolius Raddi), ${ }^{14}$ a fim de torná-las mais resistentes e para que ficassem camufladas no fundo do mar ("para o peixe não ver”). ${ }^{15}$ Essas tarefas, porém, não eram exclusivamente delas.

Cléber descreveu, detalhadamente, o processo de tingimento das redes, feito por ele pela última vez há três anos:

\footnotetext{
${ }^{14} \mathrm{O}$ pequeno fruto da aroeira também é utilizado para fins medicinais (como cicatrizante de feridas) e culinários, sendo comparado com a pimenta rosa quando se descobre a semente da casca que a recobre.

${ }^{15}$ Não registrei essa prática em minhas observações. De acordo com os pescadores, não é realizada há alguns anos.
} 
Cléber: Para dar tinta na rede, a gente usa um tacho de cobre, que cabe mais ou menos uns 150 a 200 litros de água. Primeiro, tem que contratar o rapaz para ir lá na floresta, descascar a árvore para panhar a casca do murici. Aí, ele traz para mim enquanto tá verde ainda que é para poder socar até ela se desfiar toda. Aí, bota para enxugar; depois de enxugar, ensaca de novo e guarda. Aí, tem que caçar água, que seja de poço, sem cloro, para não interferir na tinta. E aí, pegar e botar a tinta de molho três dias para soltar bem o sumo; depois, queimar ela e ferver e, depois, passar a rede de nylon seda dentro daquela tinta para tingir - igual tinge um tecido. [Isso] fortalece, deixa ela durinha para ficar arrumadinha na canoa, para ela ficar armadinha e protege o nylon e escurece ela para dar uma tonalidade pro peixe também não vê. Depois que der a tinta na rede, você tem que botar ela para enxugar, embarcar ela e ir lá pescar pra água de sal apertar a tinta; depois você tem que estender a rede de novo, enxugar e começar a preparar outra tinta, porque você tem que dar umas três tintas para ela ficar bem legal.

Atualmente, há pouquíssimas pessoas que dominam esses saberes. Não encontrei mulheres versadas nessas práticas tradicionais. A maioria dos pescadores de rede de espera, ainda que saiba repará-las, compra as redes prontas (de "nylon plástico"), bem como uma tinta industrial para tingi-las, quando é o caso. Esses produtos são encontrados no Mercado São Pedro, mercado municipal de peixes e frutos do mar de Niterói, localizado no bairro da Ponta d'Areia.

Os meninos começam a pescar, em média, a partir dos 10 ou 15 anos. Antes disso, porém, já têm contato com o mar. Há relatos de pais que fabricam "reminhos" (pequenos remos de madeira) para que os filhos, ao brincarem, tenham um contato inicial com a atividade, como fizera o pai de Seu Euclides.

Quem me contou um pouco sobre esses ritos de iniciação foi Seu Vadinho, um antigo pescador aposentado, que também reside no Tibau. Acompanhado da amiga Luciana Loto, cheguei à casa situada na Rua das Conchas, $\mathrm{n}^{\circ} 77$, por intermédio de Cléber, que sempre me incentivou a ouvir as histórias dos mais velhos. ${ }^{16} \mathrm{Na}$ ocasião, solicitou a Kiko que nos mostrasse onde morava o velho pescador. Além da câmera e do tripé, levamos, a pedido de Cléber, um peixe espada e algumas corvinas paria presenteá-lo. Fomos muito bem recebidos.

\footnotetext{
${ }^{16}$ A princípio, fomos a Piratininga para gravar uma entrevista com Seu Euclides. Entretanto, este havia sido internado em um hospital.
} 
Seu Vadinho: Eu estava com uns quinze anos. Na verdade, eu comecei a pescar com uns 10 anos, a trabalhar com uns 10 anos. Eu comecei a pescar com o compadre Euclides. Tinha uma porção deles; eles já se foram.

As crianças também embarcam com os pais (ou parentes) e exercem algumas funções hierarquicamente inferiores, ${ }^{17}$ como à de ponta-de-cabo, que fica na areia segurando uma das pontas do cabo enquanto a canoa realiza o cerco. Essa primeira socialização com o saber-fazer que norteia a pesca permite que os aprendizes comecem a dominar as técnicas corporais (MAUSS, 2013) necessárias ao exercício da atividade, a exemplo da puxada de rede e da remada que ocorrem nas pescarias de arrasto de praia, descritas logo abaixo.

No que diz respeito à puxada de rede, vejamos o que escrevi em meu caderno de campo do dia 13 de novembro de 2015, quando participei dessa operação:

\begin{abstract}
(...) enquanto o mestre, dentro da canoa, soltava o restante da corda, nós, na areia, a puxávamos com o auxílio do "re-cabo". Este petrecho consiste em um laço do qual se destaca um pedaço de corda com cerca de $50 \mathrm{~cm}$; a parte circular é posta na cintura e o pedaço é entrelaçado na corda que compõe a rede. A tensão entre a corda do "re-cabo" e a corda da rede permite que o corpo de quem o utiliza fique inclinado para trás, diminuindo tanto a pressão nos joelhos, quanto a força que se faz com os braços. Vale ressaltar que não é necessário amarrar o "re-cabo" na corda, pois o nó de sua extremidade permite que, ao ser tensionado, não desamarre. Além disso, como a operação exige esforço e sincronia, havendo uma alternância dos membros da "puxada" - conforme a corda é puxada, cada um assume as posições mais próximas à água -, o "re-cabo" deve ser afrouxado com facilidade.
\end{abstract}

Em relação à remada, vivenciei algumas experiências que demandaram a "correção" da postura do meu corpo. Nas vezes em que embarquei a convite de Cléber, mestre da canoa, sempre exerci a função de remador (ou remeiro). O uso

\footnotetext{
${ }^{17} \mathrm{O}$ princípio hierárquico que rege uma companha não deve ser confundido com relações verticais de mando de desmando. Trata-se, ao contrário, de uma relação entre um todo (ou um conjunto) e um elemento desse todo (ou conjunto): "o elemento faz parte do conjunto, é-lhe, nesse sentido, consubstancial ou idêntico e, ao mesmo tempo, distingue-se dele ou opõe-se-lhe" (DUMONT, 1993, p. 129).
} 
do remo exige força, agilidade e coordenação, uma vez que é preciso sincronizar o movimento do seu remo com o dos demais remadores. Além disso, deve-se estar atento aos comandos e às coordenadas dadas pelo mestre. Minha atenção voltavase, também, para os companheiros, que me estimulavam ou repreendiam: "Vamos lá, Gabriel!”; "Vamos remar juntos!”; “Solta o corpo!”; “É isso aí, nego!”; “Presta atenção!”. Aprendi que meu tronco não poderia ficar ereto; era necessário soltá-lo, acompanhando o ritmo dos remos. As pernas deviam estar esticadas e as mãos não podiam ficar muito afastadas ao segurar o remo, sob pena de se empreender um esforço maior.

\subsection{2.}

\section{A pesca marítima}

\section{a) \\ Arrasto de praia}

As artes de pesca e os saberes que as norteiam não estão estanques no tempo. Ainda hoje, diferentes estratégicas de captura são praticadas em Piratininga; outras deixaram de sê-lo, a exemplo do cerco com vigia, que, mesmo ausente - não é praticado há mais de 20 anos -, continua presente nas representações coletivas.

Seu Vadinho: Pescava-se com rede de cerco, conforme ainda tem na lagoa. É diferente da praia para a lagoa. A rede de lá [da praia] tem o nome de arrastão; a rede da lagoa é rede de malha. A pesca de rede de espera apareceu agora. Existia a rede alta, que ainda tem agora.

O cerco com vigia, assim como o lanço à sorte, é uma modalidade do arrasto de praia (ou arrastão), pescaria realizada com as tradicionais canoas de um tronco só (feitas de troncos cavados). Em média, estas embarcações têm $7 \mathrm{~m}$ de comprimento e utilizam apenas remos. Pode ser encontrada em outras praias do litoral fluminense, como Itaipu (KANT DE LIMA; PEREIRA, 1997; PESSANHA, 2003; MIBIELLI, 2004), Arraial do Cabo (BRITTO, 1999; PRADO, 2002; LOBÃO, 2010; LOTO, 2012), na Ilha da Marambaia (MOTA, 2003) e na Lagoa 
Feia, na região norte do estado (COLAÇO, 2012). Atualmente, contudo, sua fabricação está restrita à cidade de Paraty $(\mathrm{RJ})$, segundo os pescadores locais.

Figura 21 - Canoa "Começo da Vida".

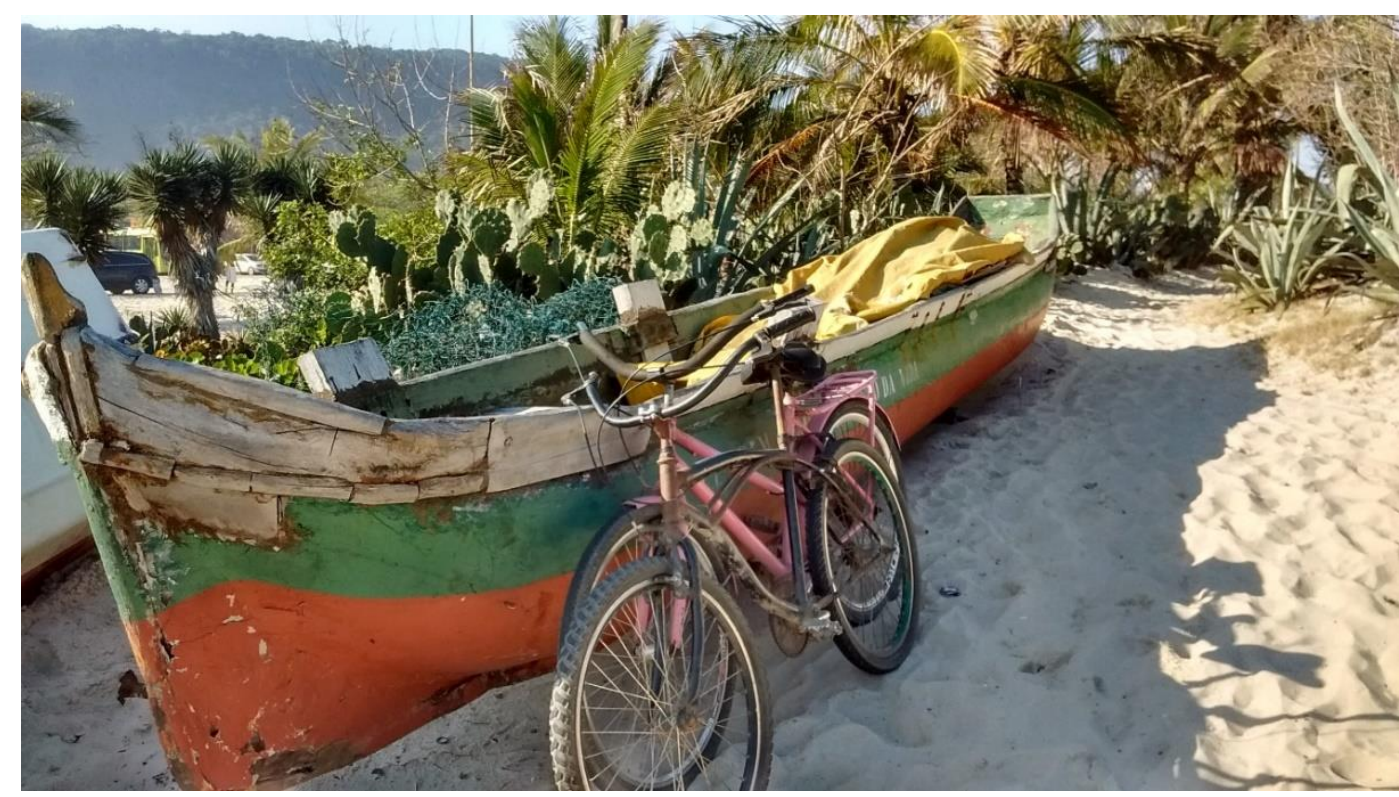

Fonte: Elaborada pelo autor.

A pesca consistia em realizar um cerco na beira da praia e, em seguida, puxar a rede. Iniciava-se com o sinal do vigia, que, sobre uma pedra, indicava onde estavam os cardumes. Na canoa, o processo era dirigido pelo mestre, que se encontrava em pé na popa da embarcação e com um timão (ou leme) em mãos. Quando a canoa descia da praia (arriar ou desencalhar) e entrava na água, começava-se a remar até a posição certa. Depois, soltava-se o cabo do início da rede na praia, onde se encontrava o cabeiro (ou ponta-de-cabo), que esperava o sinal do mestre para começar a puxar. No momento de jogar a rede na água, a velocidade do chumbereiro e corticeiro dependia da intensidade do trabalho dos remeiros para dar forma precisa ao cerco. O momento de fechar o cerco e navegar até a praia era decidido pelo mestre que dava ordens ao restante da companha.

As companhas, isto é, as equipes constituídas para a pesca, eram compostas por um mestre, um contramestre, quatro remadores (ou remeiros), um ponta-decabo e um vigia. Em Itaipu, tinha-se a mesma divisão do trabalho (PESSANHA, 2003, p. 86). 
Cléber: A pescaria era como uma empresa. Cada companhia tinha cerca de 10 pessoas; fora as outras que se envolviam indiretamente. Por isso eu tô nisso, é uma pesca comunitária.

O vigia comandava a pescaria. Ele determinava o lugar e a hora para se colocar a rede. Posicionado no alto de uma pedra próxima ao costão do Imbuí, o vigia observava a chegada e a localização dos cardumes, identificava as espécies e até calculava a quantidade que poderia ser capturada. $\mathrm{O}$ domínio desse saber naturalístico (LÉVI-STRAUSS, 1989) colocava-o em uma posição de grande responsabilidade.

Seu Vadinho: Naquela época era muito peixe; o pescador via o peixe e cercava. Tinha o vigia que comandava a pescaria. Não era o que estava na popa, nem o dono, nem o mestre. Era o vigia que ficava na praia. Era muito peixe, rapaz. Dava tudo quanto é marca de peixe: muita tainha, muita anchova, muita corvina, muito xerelete.$$
* * *
$$

Cléber: O vigia tinha que conhecer o mar e o cardume de peixe; fazia o cálculo do cardume. Se as duas redes tivessem prontas para pescar, quem tivesse duas pescarias tinha duas chances de pescar.
\end{abstract}

A companha aguardava prontamente o sinal do vigia. Quando este abaixava o braço, sinalizava que os cardumes aproximavam-se. Dava-se início à pescaria. Mas, como havia muitas companhas, seus respectivos vigias poderiam abaixar o braço ao mesmo tempo, o que provocaria conflitos. Para evitá-los, os pescadores criaram uma regra denominada direito à vez, também observada em Itaipu (KANT DE LIMA; PEREIRA, 1997) e que valia para o lanço à sorte.

Cléber: Para o cara ser o primeiro a cercar, os caras vinham de Itaipu remando... Por exemplo, vamos tomar o lanço. Eu cismava com a minha tripulação: "Vamos lá tomar o lanço!". Vambora, a rede tá embarcada, redonda, tudo conforme tem que ser para fazer o cerco de tainha: a equipe completa, ponta-de-cabo, a rede embarcada redonda - não é assim à moda caralho. E aí, ou a gente ou eles rema até o meio da praia - à altura do, agora não tem mais, Castelinho -, chegava lá, 
arriava a âncora, ficava uns 10 ou 20 minutos. Depois, levantava a âncora e vinha embora para cá. No outro dia de manhã, a gente já sabia que era o primeiro. [A regra valia] para todos os lugares. Se você viesse de fora para cá, você era o primeiro normalmente.

O direito à vez possibilitava uma alternância entre as canoas que fariam o cerco ou o lanço. Em Piratininga, esse direito era exercido de acordo com o número de canoas de cada dono, o que poderia causar conflitos. Conta-se, por exemplo, que um determinado dono de pescarias, de "olho grande", passou a possuir cinco canoas para poder pescar mais vezes em um mesmo dia. Como reação, suas canoas foram avariadas pelos pescadores descontentes.

No que diz respeito às relações entre Piratininga e Itaipu, os pescadores relataram que, na "disputa da tainha durante o inverno", havia conflitos quando as regras eram desrespeitadas. No entanto, "todos conheciam as regras criadas pelos pescadores artesanais de canoa".

Cléber: Os cardumes dormem na pedra e, pela manhã, começam a andar. Para ser o primeiro a cercar e não bater de frente com outra canoa, tem que ir, por exemplo, até o Praião e arriar a âncora. De uma maneira ou de outra eles ficavam sabendo. De manhã você chegava lá e tinha outra canoa, mas o cara sabia que você era o primeiro.

Ao que tudo indica a existência de regras por si só não era capaz de evitar conflitos. Ainda segundo Cléber, "na última vez que fizemos o cerco, os dois vigias abaixaram juntos. Deu uma merda. Os ânimos só se acalmaram porque todo mundo matou um pouquinho".

Outra figura importante na companha é o mestre, responsável pela pescaria, na dupla acepção desta categoria: responsabiliza-se pelo conjunto de equipamentos pertencentes ao dono da pescaria (que pode ser ele mesmo) e pela pescaria propriamente dita (o ato de pescar). É ele quem decide como será executada a pescaria. É ele quem determina o ritmo e a velocidade a ser imprimida pela canoa:

Ele deve sair na 'popa', com os 'companheiros de remo', 'largar' a rede, auxiliado pelo 'ré', quando embarcada 'à moda de rede alta', eventualmente cobrá-la, pilotar a canoa durante o 'lanço' com auxílio do timão e, após a chegada da segunda extremidade da rede à praia, voltar a seu 'cópio' remando à popa, com o timão, e 
orientar sua 'puxada'. Depois da chegada da rede à praia, compete a ele a distribuição e comercialização do produto" (KANT DE LIMA; PEREIRA, 1997, p. 165).

Dentro da canoa, o mestre ocupa a posição mais alta na hierarquia da pesca. Para exercer tal papel, o pescador deve passar, antes, pelas demais funções, de modo que domine o maior número de saberes ("tem que saber de tudo da canoa e do mar"). Além disso, segundo um mestre me relatou, "tem que ser corajoso".

Empiricamente, observei que o mestre deve ser respeitado dentro da embarcação, ou seja, "é imprescindível administrar as redes de sociabilidades internas à companha" (SARAIVA, 2004, p. 30). Sua autoridade deve ser reconhecida pelos membros da equipe. Externamente, é imprescindível que os pescadores mais velhos - antigos mestres ou não - o reconheçam. Quando isso ocorre, eventualmente auxiliam-no em algumas atividades, como o reparo de canoas e redes ou o reforço durante o lanço à sorte (nas puxadas de rede ou na operação de enrolar os cabos). Não obstante, o mestre também é respeitado por parentes, amigos e vizinhos que compreendem sua posição.

Nesse sentido, nem todo mundo pode ser mestre. Cléber, que conheceu Piratininga na tenra idade, quando passou a vender milho na praia, recorda-se de uma máxima proferida por Seu Euclides, em meio a uma discussão entre companheiros a respeito de quem seria ou não mestre: "Mestre merda e muleta se escreve com a mesma letra".

Cléber fora iniciado, como ponta-de-cabo, na companha de Mundinho, um dos mestres locais à época. Tentei traçar, a partir de suas lembranças, um quadro que desse conta dos mestres que o antecederam. Na década de 1970, assumiram tal função o mencionado Mundinho, Nelinho (pai de Amilton), Dozinho (pai de Trico, que também era vigia) e Seu Euclides. Segundo contou, Zequinha, Cambuci, Natalino e Manel Lagarto, todos de Itaipu, também pescavam em Piratininga. De 1980, Cléber recorda-se de Joel (que veio de Charitas). De 1990, destacaram-se Tinga, Trieste, Jorge, Nazaro, Seu Dudu e o próprio Cléber.

A posição de mestre foi assumida por Cléber quase que “involuntariamente". Seu Dudu, antes de se embrenhar na pesca, exercia outra atividade profissional. ${ }^{18}$ Depois de se aposentar, ingressou na companha de Tinga.

\footnotetext{
${ }^{18}$ Sobre a trajetória de Seu Dudu em Piratininga, ver Saraiva (2004).
} 
Mas a despeito dos esforços de Seu Dudu, Tinga entregava-lhe um quinhão sempre inferior ao dos demais membros da companha. Insatisfeito, contou a situação a Cléber:

Cléber: Ele veio falar comigo todo triste, dizendo que Tinga não repartia direito. Como eu não gosto de injustiça, sugeri a ele que comprasse a canoa de Trieste e que montasse sua própria companha. Aí, ele mostraria ao Tinga que ele também poderia ser pescador: de empregado à patrão.

Seu Dudu não apenas aceitou a sugestão de Cléber como o colocou como "sócio" da nova empreitada. À época, Cléber dedicava-se a outros tipos de pescarias (rede alta, caceia, corvineira e linha), o que o fez recusar a proposta. Mas cedeu pela insistência de Seu Dudu. Dessa forma, além da canoa de Trieste, compraram, por $\mathrm{R} \$ 1.600,00$, um tacho de cobre para o tingimento das redes e uma outra canoa de Tinga - que só tinha os "bordos" e o fundo -, com o objetivo principal de colocar Seu Euclides em atividade novamente. Isso porque, embora este quisesse consertála, Tinga disse que só o faria quando o mar trouxesse as madeiras necessárias. Indisposto a esperar pela benevolência das marés, Cléber comprou, em nome da associação, o material que seria utilizado. Construiu, ainda, ao lado da sede da Alpagoa, uma estrutura coberta com palhas, a fim de que Seu Euclides pudesse ter um espaço para trabalhar - onde veio a ocorrer o primeiro incêndio.

Notei que Seu Euclides serve de inspiração para Cléber: "Eu me espelho nele, porque é um cara justo; sempre dividia os peixes que pescava; e pescava muito", afirma. Cléber, inclusive, o contratou com carteira assinada, para que cuidasse da manutenção das canoas e das redes. Depois do incêndio do barracão, contudo, não pôde mais arcar com os encargos. 
Figura 22 - Cléber coordena as etapas finais do cerco.

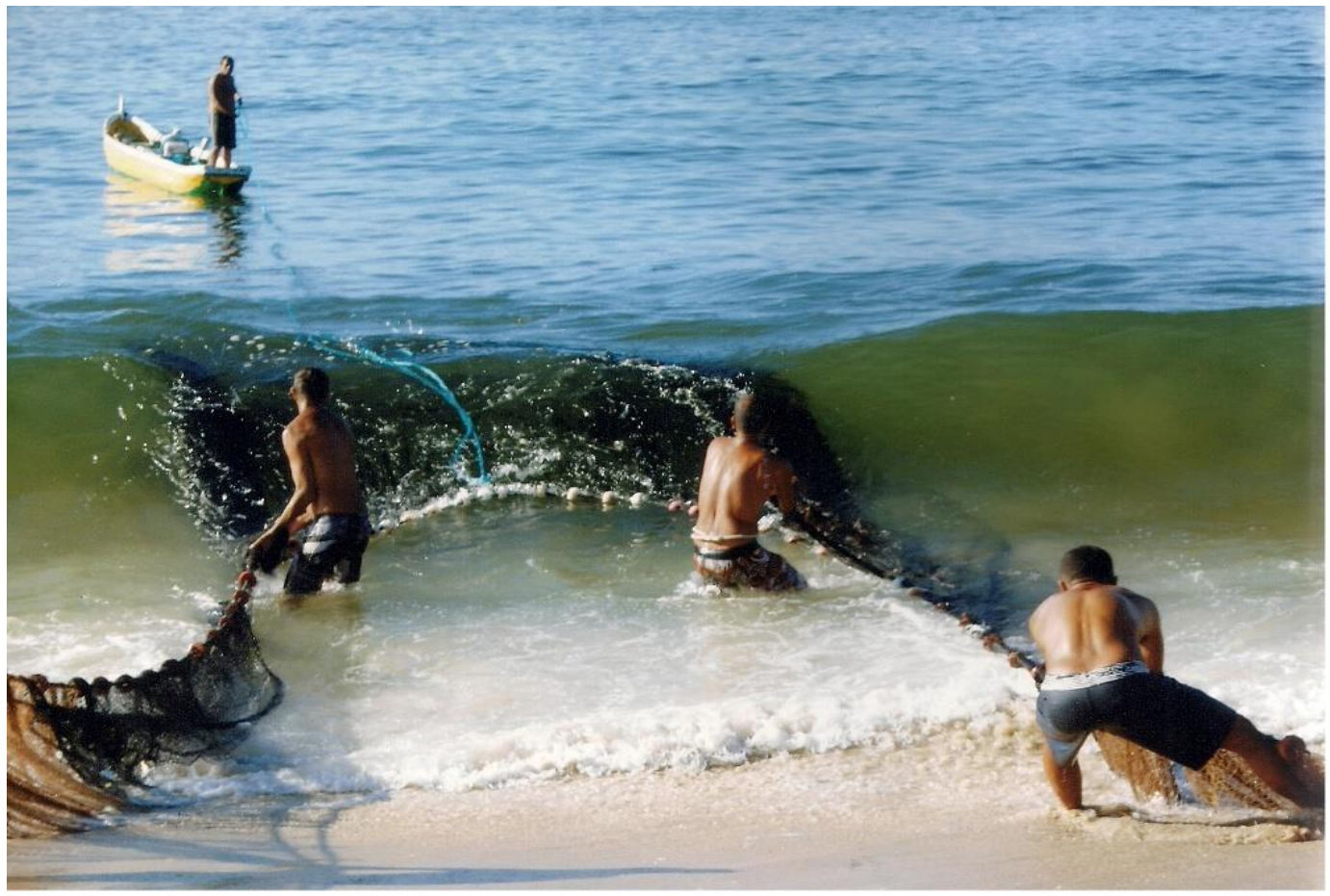

Fonte: Acervo Alpagoa.

No que diz respeito ao dono, este tem a propriedade do conjunto de aparelhos que compõe a pescaria: canoas, remos, redes etc. Ele pode acumular a função de mestre - como ocorre com Cléber. Caso não acumule, fora da canoa o dono está acima do mestre. Mas essa afirmação deve ser relativizada, principalmente se o dono não for pescador ou não dominar o saber naturalístico indispensável à atividade (SARAIVA, 2004).

Embora o cerco com vigia não seja mais praticado, o lanço à sorte - outra modalidade de arrasto de praia - ainda é exercida em Piratininga. Denomina-se "à sorte" porque se faz um cerco sem saber que tipo de peixe será pescado. Assim, a variedade de espécies nesse tipo de pescaria é alta em relação à antiga pescaria de arrasto, na qual se pescavam cardumes específicos.

A operação é basicamente a mesma do cerco, mas sem a presença do vigia. O local onde se faz o arrasto é determinado pelos pássaros que lá mergulham, indicando a aglomeração de peixes. Para realizá-lo, é necessário que haja aproximadamente nove pessoas: cinco ou seis pessoas dentro da canoa para fazer o cerco (três remeiros, um mestre e duas pessoas jogando a rede) e seis pessoas para puxar a rede (três de cada lado). 
Pesca-se durante todo o ano, quando as condições do mar permitem, mas é preferível que seja no verão, quando o mar está mais "manso" (“o verão é mês de mar manso; venta mais de leste - vem de terra -, quase não venta sul - que vem do mar"). Utiliza-se uma rede arrastão de $800 \mathrm{~m}$ de comprimento, $10 \mathrm{~m}$ de altura e com malha entre 40 e $50 \mathrm{~cm}$ nas laterais da rede e $10 \mathrm{~cm}$ no cópio.

Em relação à pesca da tainha na Prainha, como os cardumes entravam pelo canal - situado entre a Ilha do Veado e o Bico do Papagaio - e vinham no sentido oeste-leste, o cerco ou o lanço à sorte eram feitos nessa direção. Atualmente, faz-se o lanço na direção contrária, o que, segundo alguns pescadores de rede de espera, não é a maneira correta:

Trico: O certo é fazer daqui [esquerda de quem chega à praia] para lá [direita], porque é de onde o cardume vem. Se fizer diferente, durante o cerco a canoa vai para cima da rede e fica mais difícil para soltar as cordas. Na época da tainha o cerco tem que ser bem mais rápido.

Hoje, sem saber explicar o porquê da mudança, Cléber sai pela esquerda, navega paralelamente à costa e, depois, deixa a ponta do cabo no lado direito, cercando inversamente à prática pretérita. Já no Praião, depende das marés, sendo necessário acompanhá-la: maré indo para leste, cerca-se da direta para a esquerda; indo para sul, da esquerda para a direita.

Uma das principais dificuldades na realização do lanço à sorte, atualmente, é a ausência de companheiros. A formação de uma equipe (categoria mais utilizada do que companha) ocorre por cata-cata, isto é, tenta-se reunir um número minimamente ideal de pescadores, levando-se em conta a disponibilidade, a proximidade ou o simples fato de estar na praia no momento em que a pescaria é planejada. Eis um dos motivos que possibilitaram a minha participação na pesca. A única canoa em atividade às vezes navega com três ou quatro pessoas. Além disso, conta-se com voluntários quando ocorre a puxada de rede.

Em uma das primeiras vezes que embarquei, a equipe contou com a presença de um pescador que, no passado, havia sido mestre de uma companha. Ele estava contrariado devido à demora do início da pescaria, principalmente porque havia chegado na praia às $5 \mathrm{~h}$. Em resposta a sua reclamação, Cléber disse que também 
estava desde cedo na praia, mas que não podia fazer nada se as pessoas não chegavam no horário marcado:

Cléber: Eu não tenho compromisso com pescador porque não tenho companha. Não tenho como pagar, então não posso exigir nada dos caras.

Posteriormente, Cléber me contou que o mencionado pescador passou por alguns infortúnios. Tudo teria começado a partir do momento em que "cresceu o olho; depois disso, nada mais deu certo". Certo dia fez o arrasto, sem, contudo, obter êxito. No dia seguinte, ao tentar novamente, encheu muitas caixas de peixe. No entanto, distribuiu injustamente as capturas entre os membros da companha. Seus dias de glória estavam prestes a terminar: semanas depois, sua rede rasgou ao ficar presa em uma pedra.

Quando indagados sobre o desprestígio da pesca de arrasto em oposição ao crescimento da rede de espera, já observado em Itaipu na década de 1970 (KANT DE LIMA; PEREIRA, 1997; PESSANHA, 2003), os pescadores elencam inúmeros fatores, relacionados à escassez de peixes, à ausência de pescadores, à falta de solidariedade, à especulação imobiliária e ao surgimento de novas tecnologias.

Seu Vadinho: A pesca de canoa tá acabando porque a pescaria foi diminuindo, o pescado foi diminuindo. Isso diminuiu em todo ponto de pescaria.

Cléber: Antigamente, o pessoal de fora vinha perguntar ao pescador sobre o tempo; hoje, com a globalização e a informática, eles é quem vem falar como o tempo está. Você tinha que estar em sintonia com a natureza.

$* * *$

Trico: Começou a vir traineira; veio a rede de nylon de plástico - aí ficou fácil -; teve a especulação imobiliária, e muita gente foi trabalhar na construção civil. Antigamente, a gente ficava na praia o dia inteiro, esperando o peixe e atento ao sinal do vigia. 
Jorge: Hoje em dia ninguém vive da pesca; todo mundo faz outra coisa. Eu sou aposentado. Mas a gente pesca para manter a tradição.

Os pescadores percebem que houve uma reconfiguração da ocupação do espaço da praia. Se antigamente eles ficavam "o dia inteiro" na praia, exercendo inúmeras atividades; hoje, "pegam dois peixinhos e vão pra casa". O surgimento do "nylon plástico" teria torando as coisas mais "fáceis", já que não seria mais necessário saber fazer ou consertar redes; basta comprá-las prontas. Não obstante, observei que muitos pescadores ainda reparam suas redes. Além disso, apesar de incorporarem algumas tecnologias e saberes científicos à pesca (buscam, por exemplo, na televisão ou no celular, notícias sobre meteorologia) acreditam que "essa informação não pode interferir no processo da pesca artesanal. A previsão da tecnologia pode errar".

\section{b)}

\section{Rede de espera}

No que diz respeito à pesca com rede de espera, esta reúne um maior número de adeptos. ${ }^{19}$ É realizada por uma ou duas pessoas e consiste em deixar a rede esticada no fundo, fixa em ambos os extremos por âncoras e sinalizada por boias e, às vezes, por duas bandeiras (quando a rede encontra-se longe da praia). A rede é recolhida no início do dia (por volta das 5:30h) para se tirar a captura (cobrar a rede). Se o mar estiver em boas condições, colocam-na novamente. Mas, se tiver pouco peixe, deslocam a rede para outro local; havendo previsão de temporal, retirase a rede da água.

As redes utilizadas são a corvineira e a linguadeira, ambas são redes baixas (ou redes de fundo). A primeira tem de 700 a $800 \mathrm{~m}$ de comprimento, $2 \mathrm{~m}$ de altura e os panos ${ }^{20}$ variam de malha entre $45,50,55,60$, até $75 \mathrm{~cm}$. Já a segunda tem de 250 a $300 \mathrm{~m}$ de comprimento, $2 \mathrm{~m}$ de altura e malha de $110 \mathrm{~cm}$. A linguadeira

\footnotetext{
${ }^{19}$ Em 2014, em conformidade com um levantamento realizado pela equipe do Nupij, 16 pessoas praticavam a rede de espera. Nos dois anos subsequentes, não houve uma alteração substancial nesse número.

${ }^{20}$ As redes são formadas pelo agrupamento de panos (cada pano tem aproximadamente $100 \mathrm{~m}$ ); quanto mais panos, maior a rede. Os panos são constituídos, por sua vez, pelas malhas (os retângulos ou "balõezinhos" da rede), que variam de acordo com os tipos de peixe que se quer capturar (ex. malha 25, malha 50 etc.). Em regra, quanto maior o peixe, maior a malha utilizada.
} 
somente é usada quando aparecem peixes de grande porte, pois a malha é maior. É comum trocar panos de redes, caso estejam rasgados ou para adequar o tipo de malha ao tamanho do peixe mais frequente em dado momento. A posição da rede é geralmente perpendicular à direção da corrente (leste ou sul). Alguns pescadores colocam a rede a favor da corrente; outros, contra a corrente.

Ao contrário das canoas utilizadas na pesca de arrasto, para a rede de espera são empregados barcos de madeira ou alumínio ${ }^{21}$, que medem entre 4,2 e 6 m de comprimento. Cinco embarcações são movidas a remo; três, a motor de 15 ou 25 hp de potência. Mas os motores não dispensam os remos, uma vez que estes auxiliam o pescador a ultrapassar as ondas da beira da praia, dando início a navegação, bem com orientam a posição da embarcação no momento de se recolher a rede.

A rede de espera é praticada o ano inteiro. No verão, quando "dá" bastante o peixe olho de cão, essa arte de pesca é complementar à pesca de linha, realizada antes de recolher a rede de espera.

Figura 23 - Rogério e seu filho Daniel tentam entrar no mar durante o inverno.

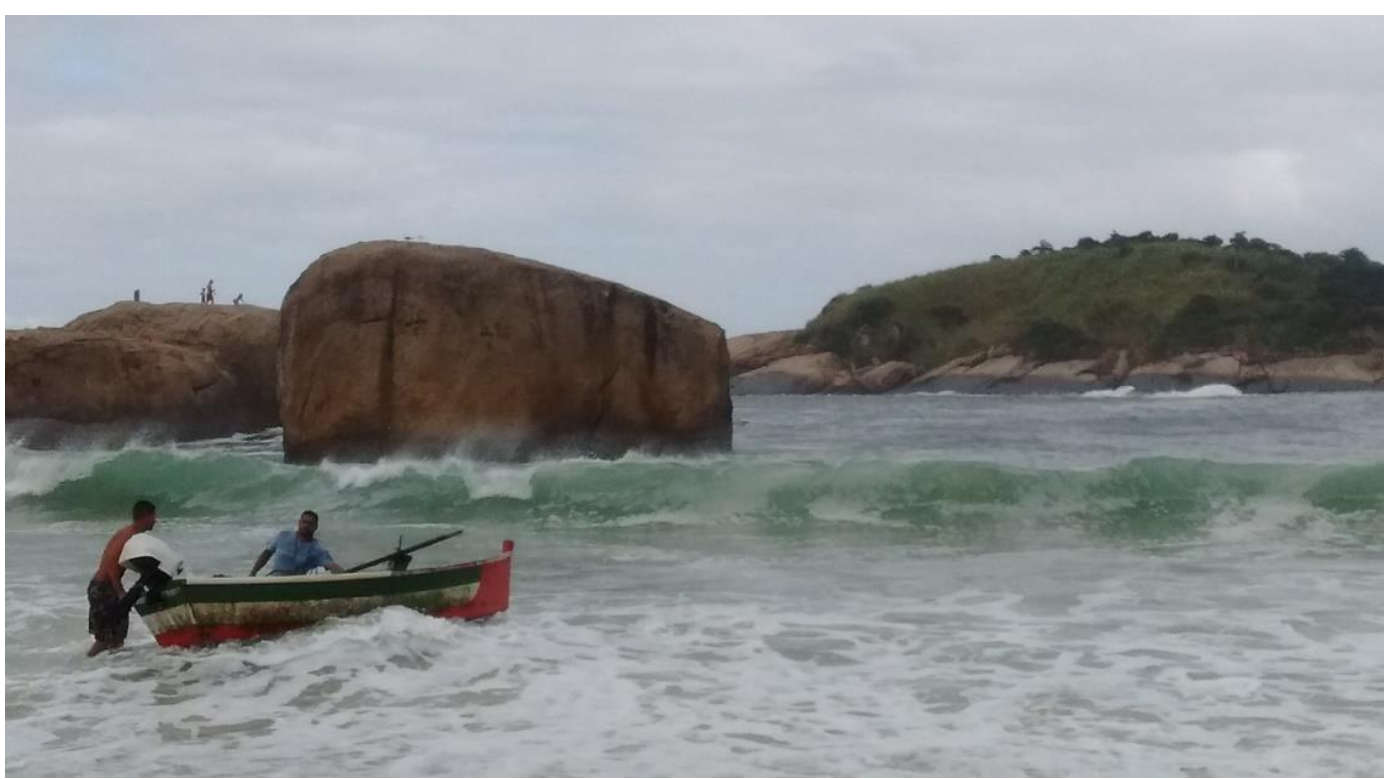

Fonte: Elaborada pelo autor.

A decisão no que diz respeito ao pesqueiro onde será colocada a rede depende do local onde se encontram os peixes-alvos - em alguns casos, são

\footnotetext{
${ }^{21}$ Em campo, também observei a utilização da categoria lancha para se referir às embarcações de
} alumínio. 
avisados pelos pescadores de linha e mergulho. Pesqueiro é a designação dada a uma formação rochosa chamada de laje, situada no fundo mar, embaixo da qual os peixes ficam ("é a morada dos peixes"; "é o lugar onde os peixes dormem"). Conforme a definição dada por Seu Maurício, "pode ser uma laje de pedra no fundo; aí o peixe junta em cima, se aglomera e o cardume vai todo para ali. Se você vai pescar e encontra ali, é um pesqueiro".

Cada pesqueiro pode "dar" diferentes espécies de peixe, a depender da época e das condições climáticas e marítimas: "Vamos supor: a água tá quente, você pode ir no Zé Mundrungo [nome de um pesqueiro] que vai matar garoupa; a água gelou, só marimbá, nem olho de cão tu encontra”, explica Seu Maurício, que se mudou de Itaipu para Piratininga depois de se casar.

Seu Maurício: O pesqueiro de polvo é só em cima da caraca da pedra por causa do marisco. Ele vem para se alimentar do marisco - não só o polvo, mas o marimbá, o sargo e outros peixes. Aqui tá acabando com o peixe por quê? A turma da Jurujuba vem, raspa o marisco e a pedra fica lisa. Aí, o peixe vai abandonando, não tem o que comer. $O$ marisco serve de criador e serve de alimento: polvo pequenininho se esconde dentro do marisco, porque ali ele vai encontrar muito caramujinho miúdo, caranguejo miúdo.

Os pesqueiros são classificados localmente e carregam uma historicidade, na medida em que aparecem nos relatos como palco de muitas ações pretéritas ("meu pai matava muito peixe ali"; “antigamente eu gostava de pescar lá"). Aparecem, também, em composições cantadas na beira da praia ou em botequins, ligadas às relações jocosas e, ao mesmo tempo, conflituosas do grupo. Em um samba, por exemplo, o compositor, amigo dos pescadores, fez galhofa com um pescador que quer colocar a rede em todos os pesqueiros que estão "dando" peixe:

Se eu vou na Galheta, ele vai

Se eu vou no Praião, ele vem

Até lá no Zé Mundrongo

Ele já está também. ${ }^{22}$

\footnotetext{
${ }^{22}$ De modo perspicaz, a amiga Izabela Fernandes notou que se trata de uma paródia do samba "Quem é ela?”, de Zeca Pagodinho e Dudu Nobre: “(...) Se eu vou na Mangueira ela vai/ Se eu vou na
} 
Galheta, Praião e Zé Mundrongo são nomes de pesqueiros, assim como Ferrinho e Passarinho. Apesar de não haver uma regra que proíba que as redes sejam colocadas nesses pontos, o fato é que alguns pescadores são mais ciosos de alguns lugares específicos. Dessa forma, se estiver "matando" muito peixe em um pesqueiro onde tem o hábito de pôr a rede, chamará de "olho grande" (ou “olhudo") aquele que quiser usufruir do mesmo lugar. Em uma marchinha, explicita-se uma dessas tensões:

Vai lá, Valmir,

Que a hora é essa!

O Catiquinho matou lula à beça.

O Catiquinho quando pesca olho-de-cão,

O Catiquinho arruma confusão.

Quanto à categoria porto, não deve ser confundida com o porto encontrado na lagoa, sobre o qual falarei mais à frente. Na praia, porto é o lugar onde ocorre a entrada e a saída de embarcações. Na Prainha, o porto vai da Pedra da Baleia até aproximadamente onde estão localizadas as canoas. Ultrapassando-se essa linha imaginária, indo na direção do Imbuí, torna-se mais dificultoso o ir e vir dos barcos, pois o mar é mais "agitado". O mesmo ocorre no Praião, onde "não dá porto". Para que haja um porto, é preciso que o mar esteja "manso".

Os usos e apropriações dos portos também são regrados pelo grupo. As observações feitas para os pesqueiros valem para o porto da praia: quando as regras são violadas ou quando inexistem, os conflitos são deflagrados. Nesse caso, se algum pescador colocar sua rede em um porto, será repreendido, diretamente, por quem foi prejudicado e, indiretamente, pelos demais pescadores.

Em uma manhã de setembro, presenciei um desses embates. Na noite anterior, Gaúcho, ao sair com sua lancha, passou por cima de uma rede, rasgandoa. No dia seguinte, Josi, o dono da rede, foi cobrá-la sem sucesso, pois encontrou seu petrecho danificado. Como as informações circulam rapidamente, já se sabia de

Portela ela estál Ela vai no Cacique de Ramos/ Ela vai no Estácio de Sál Ela vai no pagode em Xerém/ Ela vai no pagode em Irajá (...)". 
quem era a rede e quem havia passado por cima. Josi foi tirar satisfação com Gaúcho, exigindo uma rede nova. Este, contudo, alegou que a rede, além de ter danificado o motor da embarcação, estava posicionada em um lugar errado, pois se tratava de um porto. Inconformado, Josi argumentou que aquele lugar era um pesqueiro, onde ele há anos punha a rede (“o senhor chegou agora. Eu pesco aqui há muito tempo"23). Depois de ameaças e xingamentos, ambos afastaram-se e puseram fim à discussão que, por pouco, não chegou à agressão física.

Os demais pescadores mantiveram-se quase todos quietos durante a briga (alguns de cabeça baixa); poucos tentaram apaziguar os ânimos. Kiko disse-me: " $O$ ambiente ficou pesado". Esse silêncio, porém, não significava uma recusa ao conflito: nas semanas posteriores, presenciei novas tensões, envolvendo outros pescadores, em torno das regras estabelecidas em Piratininga. Nessas situações, os pescadores atribuem, frequentemente, qualificações positivas ao passado (como uma "época de ouro") e negativas, ao presente.

Trico: No tempo do meu pai isso não aconteceria. Se o cara colocasse a rede no porto ou em um pesqueiro, arrancavam ela de lá.

A lembrança da época em que o pai estava em atividade é significativa porque reivindica uma temporalidade para a regra, havendo um contraste entre o passado (quando era observada) e o presente (quando é violada).

A despeito dessas disputas, a beira da praia é um importante espaço de socialização e solidariedade (conta-se sempre com voluntários para encalhar e desencalhar as embarcações). Quando chegam do mar, posicionam seus barcos lado a lado. Enquanto limpam e vendem o pescado, conversam sobre a pescaria e as espécies capturadas; sobre venturas e desventuras. Batucam no bordo da embarcação um samba debochado e fazem comentários jocosos sobre os pescadores mais sisudos.

\footnotetext{
${ }^{23}$ A posição de Gaúcho é ambígua, pois, antes de ser pescador, ele era dono de uma padaria.
} 


\section{c)}

\section{Pesca de caceia}

Outra arte de pesca praticada em Piratininga é a pesca de caceia, geralmente complementar à rede de espera. Necessita de dois pescadores: um para remar e outro para jogar a rede. Diferentemente da rede de espera, na caceia utiliza-se uma rede alta, que "trabalha" na superfície ("velada"), isto é, captura peixes que nadam próximos à superfície da água, diferentemente das redes que atuam no fundo do mar. Essas redes têm cerca de $250 \mathrm{~m}$ a $300 \mathrm{~m}$ de comprimento, $4 \mathrm{~m}$ de altura e malha entre 50 e $55 \mathrm{~cm}$.

Ocorre com o mar "tranquilo" e durante a noite, a fim de que o mar "acenda", ou seja, com o movimento dos peixes perto da costa, micro-organismos marinhos bioluminescentes são estimulados, possibilitando que os peixes sejam "vistos".

A pesca consiste em cercar a "fortuna" em pesqueiros determinados - estes são lugares costeiros de pedra e areia. Aproxima-se com o barco perto das pedras e joga-se a rede em forma de meia-lua, fixando-se ambos os extremos. Em seguida, a embarcação entra entre a rede e as pedras, e o pescador bate com o remo ou com uma pedra para os peixes se espantarem (bate-bate) e, assim, encalharem na rede.

Deixa-se a rede fixa durante aproximadamente 30 a 50 minutos, após sua retirada com a captura. $\mathrm{O}$ cerco pode ser repetido inúmeras vezes na mesma noite, dependendo da disponibilidade de peixes e do tempo - pode-se chegar a dez vezes por noite até o amanhecer, quando se volta para a praia.

d)

\section{Pesca de linha}

A pesca de linha ocorre durante todo o ano ou "só quando o mar deixa; o tempo deixa". O instrumento dessa pescaria é a vara à qual se acopla um molinete ou carretilha (espécie de carretel no qual se enrola uma linha de nylon). À linha prende-se chumbo, anzol e isca. Projeta-se a linha no mar para que o peixe seja fisgado. Pode ser realizada sobre as pedras ou dentro dos mesmos barcos utilizados 
na rede de espera ou na caceia. Assim como a caceia, é frequentemente adotada como estratégia de captura complementar à rede de espera.

\section{e) \\ Puçá}

Realiza-se com duas pessoas. O instrumento utilizado é o puçá: armadilha feita por um aro de metal que assenta no fundo e uma rede de $20 \mathrm{~cm}$ de malha em forma de funil, com uma boia que fica sobre a superfície da água.

Quando se chega ao pesqueiro determinado, em uma embarcação, jogam-se um por um os puçás a uma distância de 10 a $15 \mathrm{~m}$ da beira da praia e aproximadamente $6 \mathrm{~m}$ de profundidade. Amarrados a uma linha de $20 \mathrm{~m}$ (geralmente 15 puçá por linha), cada puçá, cujas iscas são vísceras de peixes, tem uma boia que marca a posição paralela à praia. $\mathrm{O}$ primeiro puçá arremessado apenas é recolhido no momento em que se joga o último. Se os puçás tiverem capturado siris, recolhe-se um por um tirando a captura e jogando-os novamente no mesmo local (sobretudo as fêmeas). Essa operação dura o dia inteiro se tiver "fartura". Por outro lado, não havendo captura nesse local, recolhe-se a linha com todos os puçás, jogando-os em outro pesqueiro.

A melhor estação para essa pescaria é o verão, com lua cheia e mar "calmo". A decisão de quando e onde realizá-la depende do aviso dado pelos pescadores de rede de espera e arrasto acerca da "chegada" de peixes mordidos por siri. A pesca de puçá no mar é realizada geralmente entre janeiro e março; na lagoa, a partir de maio, período durante o qual o siri que entrou pequeno na lagoa, em janeiro, passa e ter um bom tamanho $(7 \mathrm{~cm})$, depois de 4 ou 5 meses.

\section{f) \\ Mergulho}

O mergulho é praticado em apneia ou com compressor. É realizado geralmente por dois mergulhadores que se alternam, uma vez que é necessário que haja alguém na superfície para manter, com o remo, a embarcação no local, bem como para supervisionar o bom funcionamento do compressor. O mergulho em apneia, normalmente feito por uma pessoa, ocorre a uma profundidade máxima de 
$10 \mathrm{~m}$; quando se pratica com compressor, chega-se a $20 \mathrm{~m}$. Mergulha-se o ano inteiro, caso as condições do mar permitam, sendo necessário que a água esteja "calma" e "clara" e o vento, preferencialmente, sudoeste.

Nesse caso, são utilizados os seguintes petrechos: um bicheiro para polvo, lagosta e cavaca (estes últimos podem ser capturados também com a mão), que consiste em uma vara de metal com um anzol no extremo; um arpão para a captura de garoupa; um saco de tela para recolher capturas no fundo; ou uma fieira para polvo, que consiste em um arame que atravessa o polvo, fechado com uma volta na extremidade para evitar que o mesmo escape. Além disso, os mergulhadores utilizam uma roupa de neoprene de $5 \mathrm{~mm}$, profundimetro, lanterna, faca, meias, pé de pato, luvas, máscara e canudo.

\section{g) \\ Mariscagem de mexilhão}

A coleta de mexilhão ocorre nos costões das ilhas e das pedras, no período de janeiro a março, durante a lua cheia - quando o mexilhão está mais "gordo", ou seja, antes da desova das gônadas -, preferencialmente com o mar "manso" e a água "quente" e "clara". É realizada, comumente, por duas pessoas: uma que fica no barco, mantendo a posição com o remo; outra que "cata" o mexilhão, seja na superfície ou mergulhando em apneia a $2 \mathrm{~m}$ de profundidade, com o auxílio de uma cavadeira, isto é, uma vara de madeira com um pedaço retangular de metal na extremidade. Os mexilhões são arremessados dentro de uma caixa de isopor.

Quando chegam do mar, contam com a ajuda de voluntários para encalhar, depositar os mexilhões em caixas e carregá-las, individualmente ou em duplas, para o barracão. Do mesmo modo, conta-se com voluntários para descascar os mexilhões. A etapa final consiste em ensacá-los para que possam ser vendidos. Ao contrário do que ocorre na venda de peixes, a maioria dos mexilhões são vendidos fora da praia. 


\subsection{3.}

\section{Comercialização do pescado}

Os peixes são vendidos, prioritariamente, na beira da praia. Vendem aos moradores, barraqueiros ou donos de bares e restaurantes do entorno. Não obstante, vendem para os turistas que acorrem à praia, principalmente nos fins de semana $\mathrm{e}$ feriados. A clientela é constituída pelo "pessoal que vem de fora": "Morador do Tibau, morador do Praião, morador da Rua 12, 6 e 4". Além destes, vendem para o "pessoal” do Recanto da Garças, do Trevo e do Cafubá.

Há apenas um intermediário que faz a correria (ou corre), isto é, quando a demanda é reduzida (seja porque a pescaria foi "boa" ou porque a embarcação chegou muito tempo depois das demais) essa pessoa oferece, em algumas casas do bairro, a maré, isto é, um punhado de peixes, que podem estar agrupados na mesma espécie ou em espécies diferentes. Em troca, recebe um percentual: caso ele consiga, por exemplo, $\mathrm{R} \$ 30,00$, receberá $\mathrm{R} \$ 10,00$, e o pescador ficará com o restante.

Figura 24 - Limpeza de peixes na beira da praia.

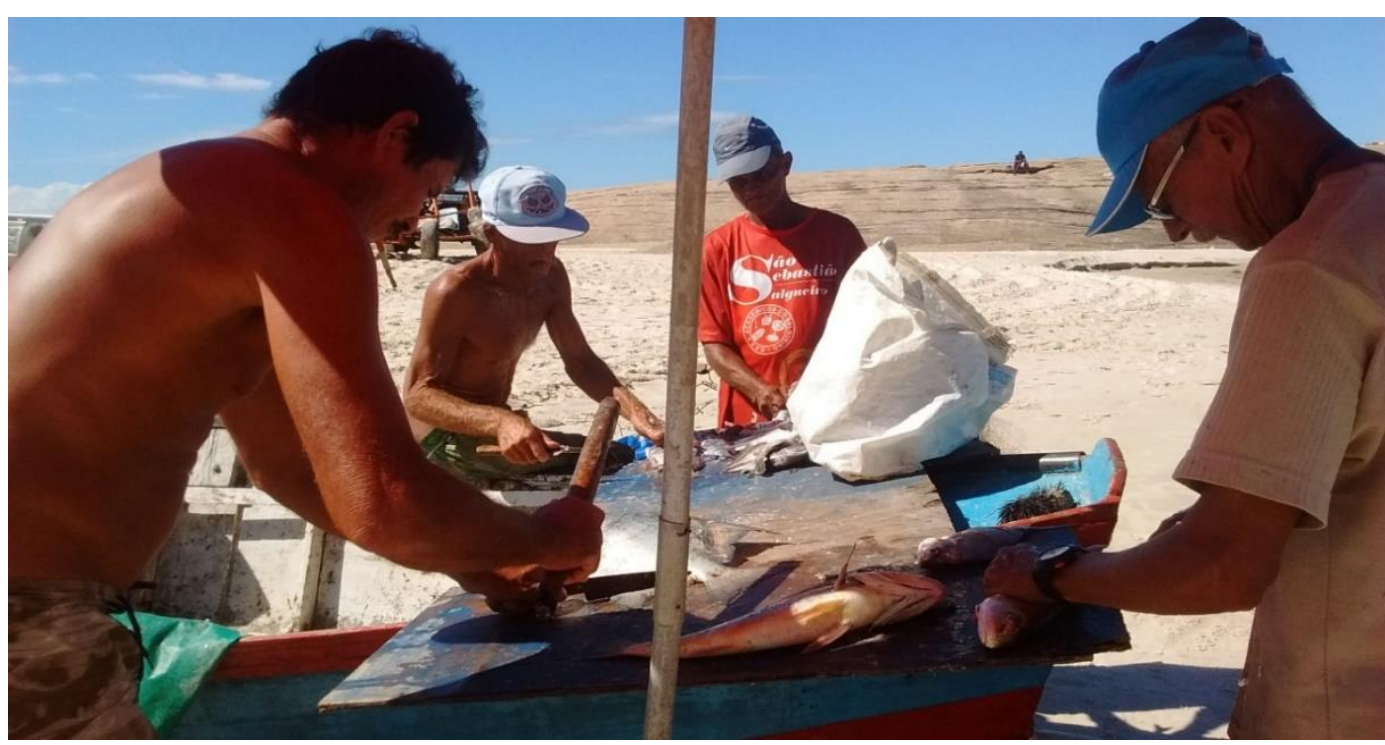

Fonte: Elaborada pelo autor.

Ademais, alguns pescadores vendem peixes em Itaipu, devido à falta de compradores em Piratininga. Para os pescadores, tanto no passado como no presente, há uma maior procura por pescado em Itaipu, pois lá a venda de peixes é 
constante. Em um passado mais remoto, antes dos empreendimentos urbanísticos que facilitaram a ligação da Região Oceânica com o centro da cidade, os peixes também eram vendidos "em Niterói” (termo utilizado para se referir ao centro do município) ou na Praça XV, no Rio de Janeiro:

Seu Vadinho: O peixe era vendido em Niterói ou na Praça XV. Na Praça XV tinha a cooperativa, que era um mercado muito forte. Ali vendia 80, 100 toneladas de peixe por dia. Eram 520 barcos com 300, 400 caixas e cada caixa com 80 kg.

Infelizmente, não obtive informações suficientes em relação à maneira pela qual os preços são estabelecidos. Apesar disso, observei que os preços do Mercado São Pedro e de Itaipu servem de referência, sobretudo se se quiser convencer o cliente do baixo custo do pescado. Os preços dependem da espécie, da época do ano, da quantidade capturada e da maior ou menor demanda. A maioria dos pescadores vende a maré. Os peixes maiores e mais valiosos, como o linguado, são vendidos a peso. Durante as vendas, são comuns as tentativas de barganha pelos compradores, bem como a realização de venda a prazo (fiado) e a doação de peixes para "inteirar no almoço" de algum conhecido.

\subsection{4.}

\section{A pesca lagunar}

a)

\section{Tarrafa}

No passado, inúmeros pescadores de Piratininga dedicavam-se à pesca na lagoa ("tinha os pescadores mais fortes"). Muitos possuíam barracos de pesca no entorno, próximos às respectivas moradas. Ainda hoje, mesmo que o "ponto de pescaria" privilegiado seja a praia, a lagoa continua a ser utilizada como espaço de pesca, de maneira exclusiva ou complementarmente à pesca marítima. De acordo com os pescadores, há mais de 30 portos no fundo do corpo de água, que se estendem do Tibau à altura do Cafubá. 
Na lagoa, porto é a categoria utilizada para designar uma determinada área onde o pescador "joga" a rede de tarrafa ${ }^{24}$ voltada à pesca do camarão (daí também o chamarem de "porto para camarão"). Para fazê-lo, é necessário retirar, com o auxílio de pá e enxada, a lama, os galhos e as raízes de árvores e as pedras que ficam no fundo da lagoa. A operação leva cerca de três dias e, além de trabalhosa, frequentemente provoca ferimentos em quem a executa. Além disso, os portos podem ser cercados com tábuas e ripas de madeira e ligados à terra por pequenas pontes estreitas.

Figura 25 - Porto na lagoa.

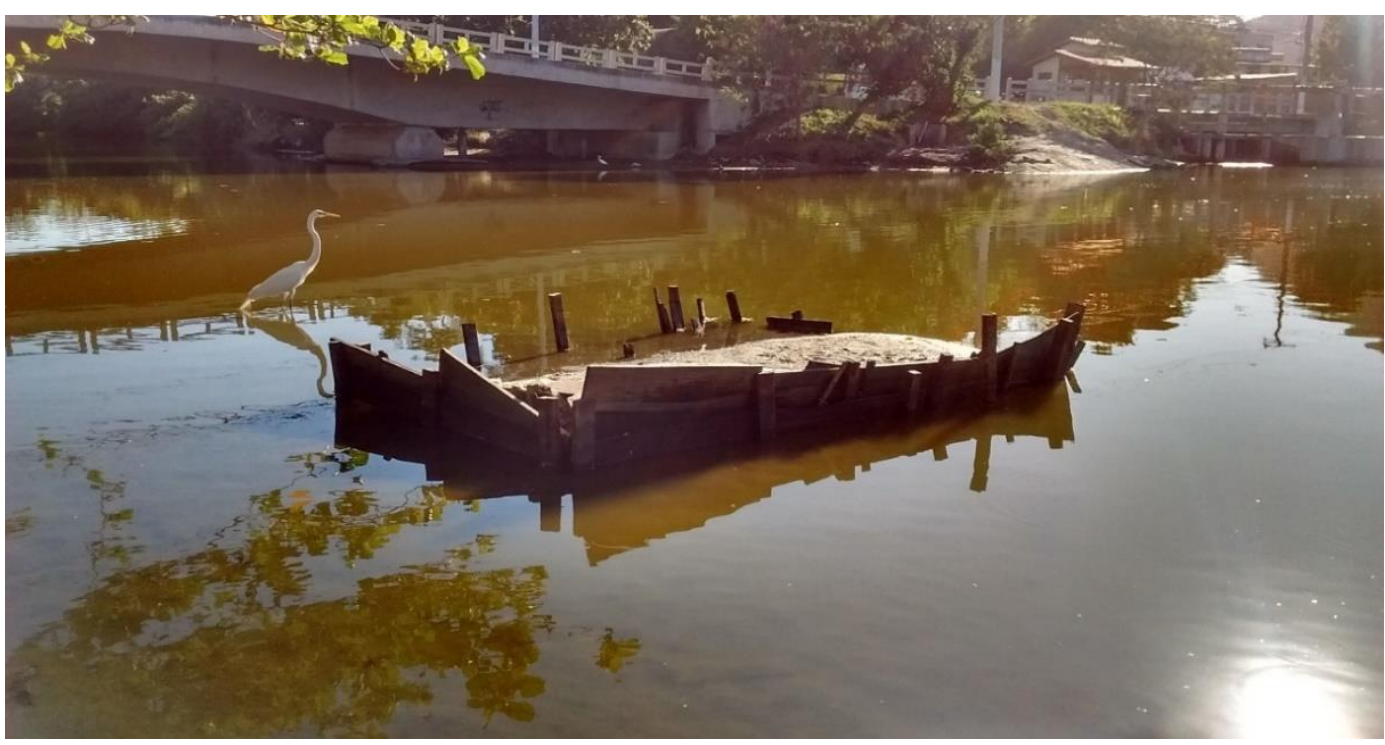

Fonte: Elaborada pelo autor.

Ao "tarrafear", o pescador fica em cima do porto, com os pés dentro d'água. Mas, antes, é necessário limpar o entorno. Isso é feito com a própria rede. Somente depois de limpo é que se pode iniciar a pescaria. Esta é realizada por uma pessoa e consiste em jogar a rede e recolhê-la rapidamente. Esse processo ocorre durante o dia ou à noite, principalmente no inverno, nos meses de junho, julho e agosto (“quando começa a dá camarão").

Há pescadores que fazem o próprio porto; outros pagam cerca de $\mathrm{R} \$ 200,00$ para que outra pessoa o faça. Não obstante, os portos podem ser transmitidos de pai para filho ou pode-se recebê-los de algum parente. Mas, independentemente de

\footnotetext{
${ }^{24}$ Rede circular com aproximadamente $3 \mathrm{~m}$ de comprimento, com malha $10-12 \mathrm{~cm}$, com chumbos cilíndricos distribuídos na circunferência e uma corda no centro para recolher as capturas.
} 
quem o preparou, o fato é que cada pescador tem o seu próprio porto. Em conformidade com a regra local, caso ele não esteja pescando, outro poderá utilizálo. Entretanto, tem o direito de pescar no porto que lhe pertence a qualquer momento.

Reginaldo (pescador da lagoa): Não é querer ser o dono da lagoa, mas o cara de fora que vem para Piratininga tem que preparar o seu lugar. Ele se faz de bobo, porque saber todo mundo sabe. Ele vê tudo limpinho, sem galho, raiz de árvore, pedra, lama.

As relações entre os pescadores de Piratininga que atuam na lagoa e os de fora (às vezes identificados como o "pessoal da favela", isto é, do Cafubá, situado no outro lado da lagoa) tornam-se conflituosas quando as regras locais não são observadas. Os pescadores sustentam que ninguém as ignora, a despeito de ser alguém de fora de Piratininga. Todavia, o problema é que hoje não haveria mais "regras", tampouco "respeito" entre os pescadores:

Seu Vadinho: Naquela época existia respeito. Então, com o tempo, aquilo ali [o porto] era seu. Era só de boca. Na época do camarão, principalmente, dava muito conflito, muitos foram parar no hospital, dava muita morte. O cara chegava e falava: "Eu vou pescar ai também, eu vou fazer isso"; aí começava a confusão.

Cléber: Antes da regra ser massacrada, os caras sentavam para afirmar o que se tinha dito. Se alguém colocasse a rede no porto, a canoa passava e colocava a rede para dentro. E o cara dizia: "Não coloca de novo, se não vai dar merda". As pessoas respeitavam.

Observei, contudo, que a existência de normas, no passado, não evitava a eclosão de disputas e tensões. De acordo com Seu Vadinho, “na época do camarão, principalmente, dava muito conflito, muitos foram parar no hospital, dava muita morte". Para ele, naquela época era "mais violento" do que atualmente. O mesmo ocorria na praia na época da tainha. Como se verá no próximo capítulo, os conflitos tendem a se acentuar nos períodos em que há uma maior possibilidade de se obter 
melhores rendimentos, seja na pesca de camarão ou tainha, seja na venda de comidas e bebidas para banhistas e turistas.

\section{b)}

\section{Rede de malha}

Além da tarrafa, outra arte de pesca praticada na lagoa é a rede de malha, também voltada para a captura do camarão. Realizada por uma ou duas pessoas, com o auxílio de uma canoa de madeira a remo (com $5 \mathrm{~m}$ de comprimento) consiste em deixar uma rede de $200 \mathrm{~m}$ de comprimento (malha de $30 \mathrm{~cm}$ ) esticada na superfície e fixa em ambas as extremidades, colocando-a no final da tarde até a meia-noite. Começa-se tarrafeando no início da rede, pois, se houver camarão, este "corre a rede". Em seguida, recolhe-se toda a rede, tira-se a captura e devolve-se à água peixes e siris pequenos. Caso não haja camarão, coloca-se a rede em outro ponto. Não é possível saber com antecipação a direção onde a rede será colocada, já que o camarão nada em qualquer direção. É realizada durante todo o ano.

Figura 26 - Trico desembarcando em seu porto, situado em frente à sua casa.

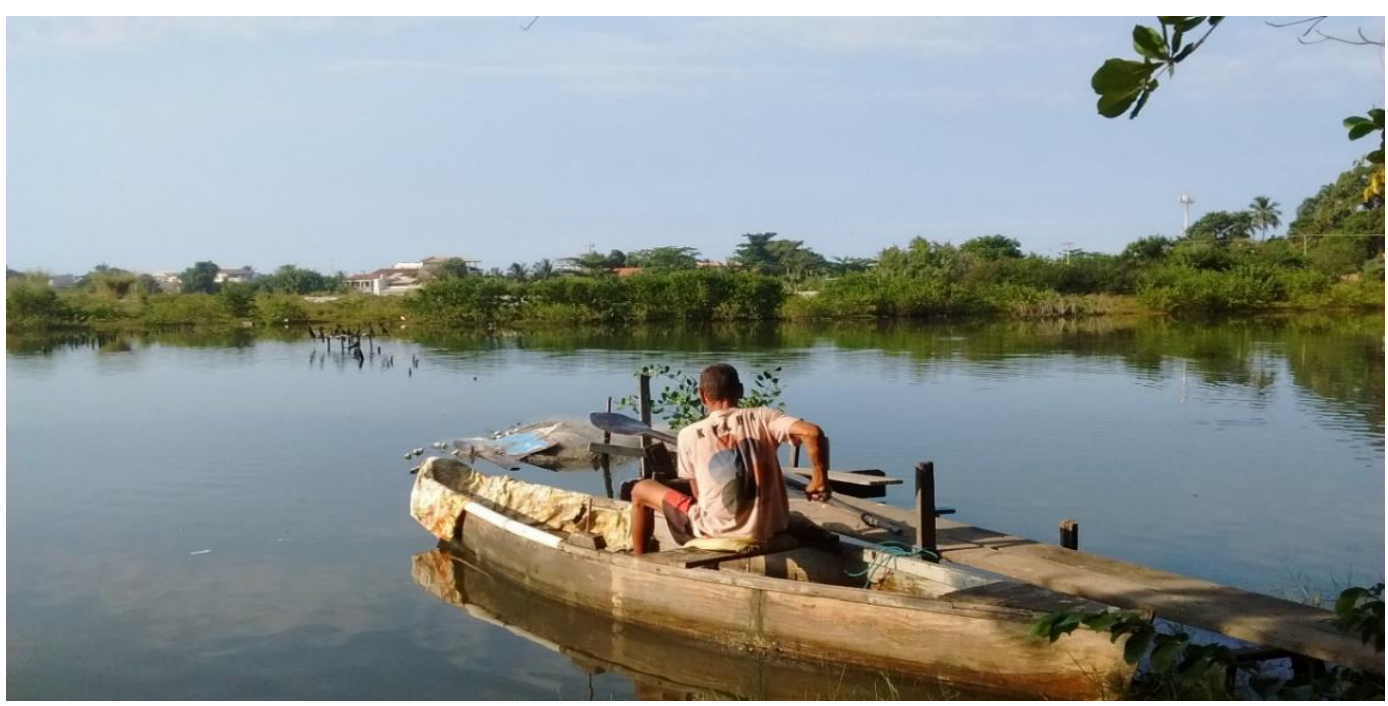

Fonte: Elaborada pelo autor.

Entretanto, a pesca na lagoa não pode ocorrer todos os dias, porque é preciso deixá-la "descansar" para que os peixes "entrem". Geralmente, a pesca é "boa" dois dias após a virada do tempo. 


\section{2.}

\section{Barraqueiros e barracas de sol}

Como observei acima, não tive a possibilidade de construir relações mais sólidas com os barraqueiros. A descrição que se segue é baseada nos relatos dos pescadores, assim como nas observações que fiz à distância - mesmo estando próximo.

Barraqueiro é a categoria utilizada localmente para designar aquele ou aquela que trabalha na praia disponibilizando, aos banhistas guarda-sóis, mesas e cadeiras. Em troca, quem se utiliza desses serviços deve consumir bebidas e/ou comidas na mesma barraca à qual está vinculado. ${ }^{25}$

Geralmente, os barraqueiros moram em Piratininga ou em localidades próximas, que possibilitam o translado do equipamento, quando é o caso. A mobília (mesas, cadeiras e barracas) possui uma inscrição que identifica a qual barraqueiro pertence; algumas também são numeradas. Em alguns casos, são levadas para a praia em uma camionete; em outros, são armazenadas em quiosques ou em construções anexadas ao barracão de pesca. Alguns barraqueiros são parentes de pescadores; outros, amigos de infância ou vizinhos.

A atividade dos barraqueiros é basicamente sazonal, havendo uma maior concentração desses trabalhadores durante o verão e, eventualmente, nos fins de semana, feriados e durante as férias escolares do meio do ano. Buscam, portanto, períodos em que a praia está densamente ocupada, o que aumenta as possibilidades de se obter melhores rendimentos.

No inverno ou "fora de temporada", o número de barraqueiros é reduzido drasticamente, permanecendo na praia, com essa finalidade, apenas os barraqueiros vinculados aos donos de quiosques do calçadão ou aos pescadores que "fazem comércio" no barracão.

\footnotetext{
${ }^{25}$ Em outras praias do litoral fluminense, como em Cabo Frio, Arraial do Cabo e Búzios, é comum a cobrança de uma espécie de "taxa de uso" quando da utilização de mesas e cadeiras, independentemente do consumo de alimentos e bebidas.
} 
Figura 27 - Barco e canoa disputando o espaço com mesas e cadeiras.

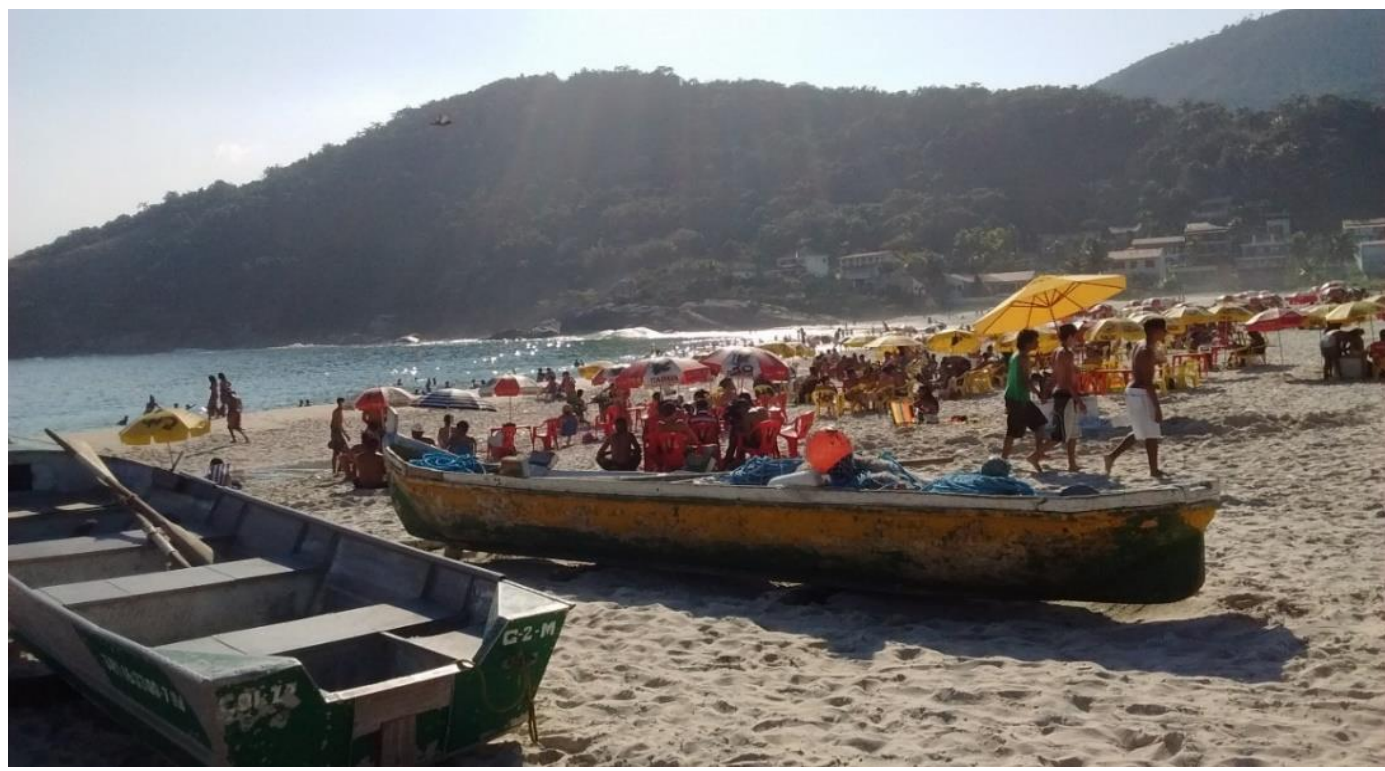

Fonte: Elaborada pelo autor.

Em função dessa sazonalidade, os espaços ocupados pelos barraqueiros não são fixos, embora, em alguns casos, um mesmo barraqueiro possa ocupar um mesmo ponto de maneira mais duradoura.

As barracas são postas em toda a extensão da praia, havendo uma espécie de linha imaginária que divide as barracas de um barraqueiro das barracas de outro. Quando a praia está prestes a entrar em erupção devido ao excesso de pessoas, não é possível distinguir nenhuma divisão espacial. Nessas ocasiões, quem consegue dar um passo à frente realiza um grande feito. O mesmo vale para as embarcações: cercadas por mesas e cadeiras, torna-se praticamente impossível levá-las para o mar.

Há, pois, uma enorme competitividade entre barraqueiros, seja pelo espaço, seja por potenciais clientes. Estes são abordados com cardápios e promoções assim que chegam à praia; às vezes, assim que descem dos ônibus estacionados no ponto final, no calçadão da praia. Mas a disputa pelo espaço também envolve os pescadores locais, seja em relação à possibilidade de se realizar a pesca, seja no que diz respeito à possibilidade de se ter um lugar ao sol, isto é, "fazendo comércio". 
4.

\section{Ação dramática}

\section{1.}

\section{A construção do objeto}

A construção do objeto está atrelada ao trabalho de campo. Como as disputas em torno dos espaços da praia, terrestre ou marítimo, estavam (estão) latentes, passei a elaborar alguns questionamentos: como são usados e apropriados os espaços dos pescadores de Piratininga? Quem utiliza esses espaços? Como são legitimadas as apropriações? Como esses espaços são classificados, percebidos e representados?

Concentrei minhas observações no barracão de pesca, onde a competitividade chegou ao paroxismo. Além disso, trata-se de um palco (um locus) sobre o qual muitos atores têm se movimentado: pescadores de arrasto de praia, pescadores de rede de espera, barraqueiros e, de maneira reflexiva, pesquisadores.

A categoria barracão, dotada de uma temporalidade, abrange uma série de interpretações. As representações a respeito desse espaço modificaram-se no decorrer do tempo; e mesmo no presente não há um consenso em relação ao seu significado. Depende de quem dele se apropria, dos usos para os quais é destinado e do contexto em que é configurado. Para alguns, trata-se de um "acampamento", de um "espaço público" ou da "sede da associação"; para outros, de uma "favela", de um "bar/restaurante" ou de um "rancho".

No caso dos pescadores, o barracão pode servir de espaço para armazenar e consertar embarcações e petrechos, para fazer reuniões da associação, para a celebração de festividades, para descansar, para comer, para vender o pescado ou para "fazer comércio", isto é, vender comidas e bebidas. Nesse último caso, o barracão de pesca confunde-se com um "bar/restaurante" e se aproxima da maneira pela qual os barraqueiros usam o espaço.

Por outro lado, como você deve ter observado acima, em alguns momentos esse espaço é percebido como um lugar: "Lugar de pescador é na praia”; "pesqueiro é o lugar onde o peixe dorme". Para compreendermos melhor a distinção entre espaço e lugar, o aporte teórico oferecido por Tuan (2012) será de grande valia. De 
acordo com ele, um lugar está permeado de relações afetivas e de sentimentos, pois é onde se vive, onde se pratica uma topofilia. O mesmo foi observado por Mello e Vogel (2004, p. 288) em relação aos pescadores de Zacarias, em Maricá (RJ), cujos lugares de reprodução social relacionavam-se ao "habito e ao diligo; à moradia ao cuidado, à estima, ao bem querer, a uma afinidade eletiva".

Um sistema de espaços (composto por categorias como "quintal", "calçada" etc.) não pode ser descolado de um sistema de valores (constituído, por exemplo, pelas noções de "público" e "privado"), e ambos mantêm uma correlação necessária com um sistema de atividades (desfrutar o lazer, trabalhar, morar etc.). Como demonstram Mello et al (1981, p. 68), “as combinações destes 'três sistemas' se situam, no entanto, num eixo temporal. Em função disso a totalidade social surge no seu caráter processual e dinâmico", abarcando diferentes contextos nos quais inúmeros papeis podem ser desempenhados.

Dessa forma, a investigação sobre os usos e apropriações dos lugares levou em consideração não apenas os espaços e suas classificação, como as atividades e as representações acerca dos mesmos. O critério espacial não foi descartado; mas não se deve confundi-lo com uma delimitação pura e simplesmente geográfica. Em conformidade com Kant de Lima (1997, p. 52) “esse espaço não é o espaço físico, mas o espaço como é representado, valorado, preenchido, pelos grupos que dele se utilizam".

Com tantas tensões, brigas e disputas, o objeto passou a ser construído sob a influência da Escola de Manchester, sobretudo no que diz respeito à analogia dos processos locais com um processo judicial, de modo que a análise deverá atentar não somente para os momentos e as mudanças, mas, também, para o conflito e seus desdobramentos (ERIKSEN; NIELSEN, 2010, p. 108-109). Complementarmente a essa noção, penso haver uma outra dimensão dos processos sociais, que "significa a operação da vida social, a maneira pela qual as ações e a própria existência de cada ser vivo afetam a dos outros indivíduos com os quais ele se relaciona" (FIRTH, 1974, p. 20). Juntas, essas duas dimensões do processo podem contribuir para a compreensão do problema aqui analisado.

O objeto desta dissertação, portanto, são os múltiplos usos e apropriações de um espaço - o barracão de pesca - a partir de uma situação específica: o conflito envolvendo pescadores que exercem diferentes artes de pesca e barraqueiros, na Praia de Piratininga, em Niterói (RJ). 
O meu foco recai sobre a disputa em torno do barracão devido à durabilidade, à gravidade e à intensidade com a qual tem sido vivenciada pelos envolvidos. Por outro lado, ao optar por essa dimensão, teremos um ponto de observação privilegiado para se entender o conflito que permeia a estrutura política do grupo.

\section{2.}

\section{O barracão de pesca}

\subsection{1.}

\section{Morfologia social}

A morfologia de um espaço é bastante representativa dos grupos sociais que o ocupam. Como sustenta Mauss (2013) em seu clássico ensaio sobre as sociedades esquimós, a forma material assumida pelos agrupamentos humanos pode afetar diferentes modos de atividade coletiva. Em Piratininga, o barracão de pesca consiste em um locus das relações sociais estabelecidas pelos pescadores locais, quer interna, quer externamente. Isso porque, além de sua variação sazonal, esse assentamento tem sido palco e objeto de inúmeras disputas.

Localizada na Prainha, de frente para a Pedra da Baleia, trata-se de uma construção improvisada com diferentes tipos de materiais: pedaços de madeira, partes de embarcações, restos de entulho, telhas reaproveitadas, varas de bambu, palhas de coqueiro, tijolos. Para Cléber, o barracão é um "acampamento", tendo em vista que não é fixo, pode ser facilmente removido e foi levantado com materiais “dados pela natureza". Por outro lado, a partir da memória vivida dos pescadores e das minhas observações, pude constatar que as reconfigurações pelas quais o barracão passou estão atreladas às necessidades, aos interesses e aos sentidos atribuídos a ele em diferentes contextos por diferentes atores. 
Figura 28 - Barracão visto da Pedra da Galheta.

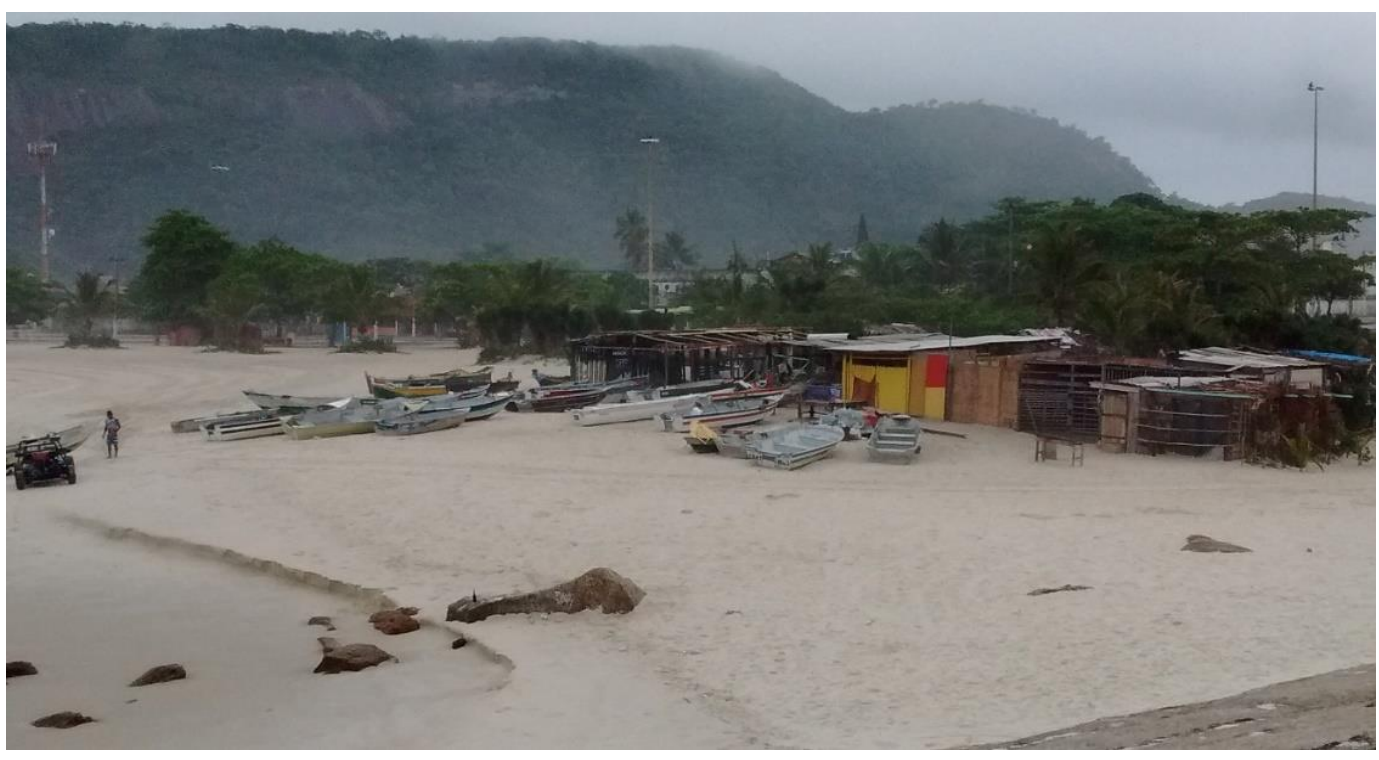

Fonte: Elaborada pelo autor.

O modelo arquitetônico do barracão, levando-se em conta as especificidades

locais, é comumente observado em outras praias do litoral fluminense, como em Itaipu (KANT DE LIMA; PEREIRA, 1997; PESSANHA, 2003), em Maricá (MELLO e VOGEL, 2004) e na Ilha da Marambaia (MOTA, 2003). Igualmente, pode ser observado na Praia da Concha, localizada no estado do Espírito Santo (FILGUEIRAS, 2008). Em algumas localidades, como na Ilha da Marambaia, a palavra barracão dá lugar à categoria rancho, além de se empregar a técnica de construção do pau a pique. ${ }^{26}$

Em Piratininga, a palavra rancho foi sugerida aos pescadores, pelo antropólogo Ronaldo Lobão, como mais propícia para figurar em um estudo de caracterização de uma comunidade tradicional, com vistas à construção de Tecnologias Sociais. ${ }^{27}$ No estado do Rio de Janeiro, a palavra barracão (ou barraco) está associada às construções mais humildes e irregulares (do ponto de

\footnotetext{
${ }^{26}$ Essa técnica também é conhecida como taipa de mão, taipa de sopapo ou taipa de sebe. Trata-se de uma técnica construtiva que consiste no entrelaçamento de madeiras verticais fixadas no solo, com vigas horizontais (geralmente de bambu), amarradas entre si por cipós, dando origem a um grande painel perfurado que, após ter os vãos preenchidos com barro, transforma-se em parede.

${ }^{27}$ Vejamos a explicação do próprio autor: "Para vislumbrar alguma possibilidade de administração desses conflitos, trabalhei com o conceito de Tecnologias Sociais, que compreendo como correspondendo a produtos, técnicas, metodologias reaplicáveis e desenvolvidas em interação com as comunidades que representam efetivas soluções de transformação social. Os contextos destes conflitos pertencem ao campo dos Conflitos Socioambientais, que entendo serem conflitos que envolvem diferentes visões sobre os significados e direitos sobre espaços naturais e/ou necessários para a reprodução material, cultural e simbólica de grupos culturalmente diferenciados" (LOBÃO, 2014, p. 45).
} 
vista arquitetônico e jurídico) das favelas cariocas. Nesse sentido, as representações dos agentes do Estado, sejam eles servidores da Prefeitura ou da Secretaria de Patrimônio da União (SPU), poderiam facilmente confundir um barracão de pesca com um barraco de favela - isso para não falarmos de um barracão de escola de samba! Em outras palavras, a categoria rancho seria mais palatável ao universo oficial.

O fato é que, conforme desdobrava-se meu trabalho de campo, aos poucos a "categoria antropológica" transformava-se em "categoria nativa". Ainda que utilizem com mais frequência barracão, hoje já é possível ler em algumas placas fixadas à parede: "rancho artesanal".

Os tamanhos dos barracões também variam, a depender da quantidade de petrechos e do número de pescarias de cada pescador. A finalidade, porém, é basicamente a mesma em todos os lugares mencionados, assim como em Piratininga: guardar embarcações, petrechos e pescados, fazer reparos e confeccionar redes. Não obstante, serve como espaço de socialização, de articulação política, de lazer, festejos e de conversas sobre trivialidades e condições do mar. Desse modo, diferentemente do que foi observado pela antropóloga Francisca Miller no Amazonas, ${ }^{28}$ os barracões encontrados nas praias do Rio de Janeiro não consistem em espaços controlados por intermediários ("atravessadores"), tampouco funcionam como uma espécie de "armazém".

\footnotetext{
${ }^{28}$ Comunicação particular feita durante a apresentação do trabalho Uma etnografia de um "barracão" de pesca, no $40^{\circ}$ Encontro Anual da ANPOCS, realizado em Caxambu (MG), de 24 a 28 de outubro de 2016.
} 
Figura 29 - Barracão utilizado para armazenar embarcação e redes.

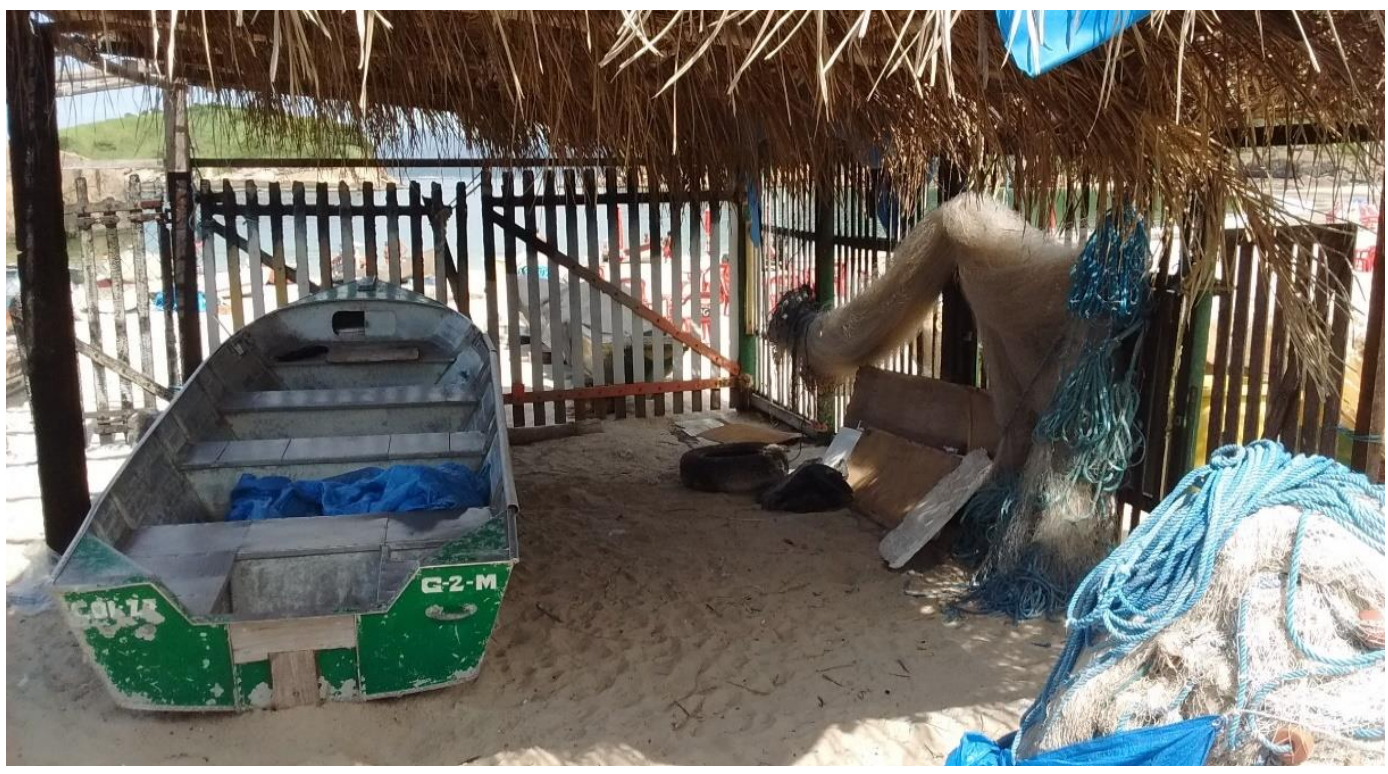

Fonte: Elaborada pelo autor.

Figura 30 - Barracão utilizado para celebrar uma festa de aniversário.

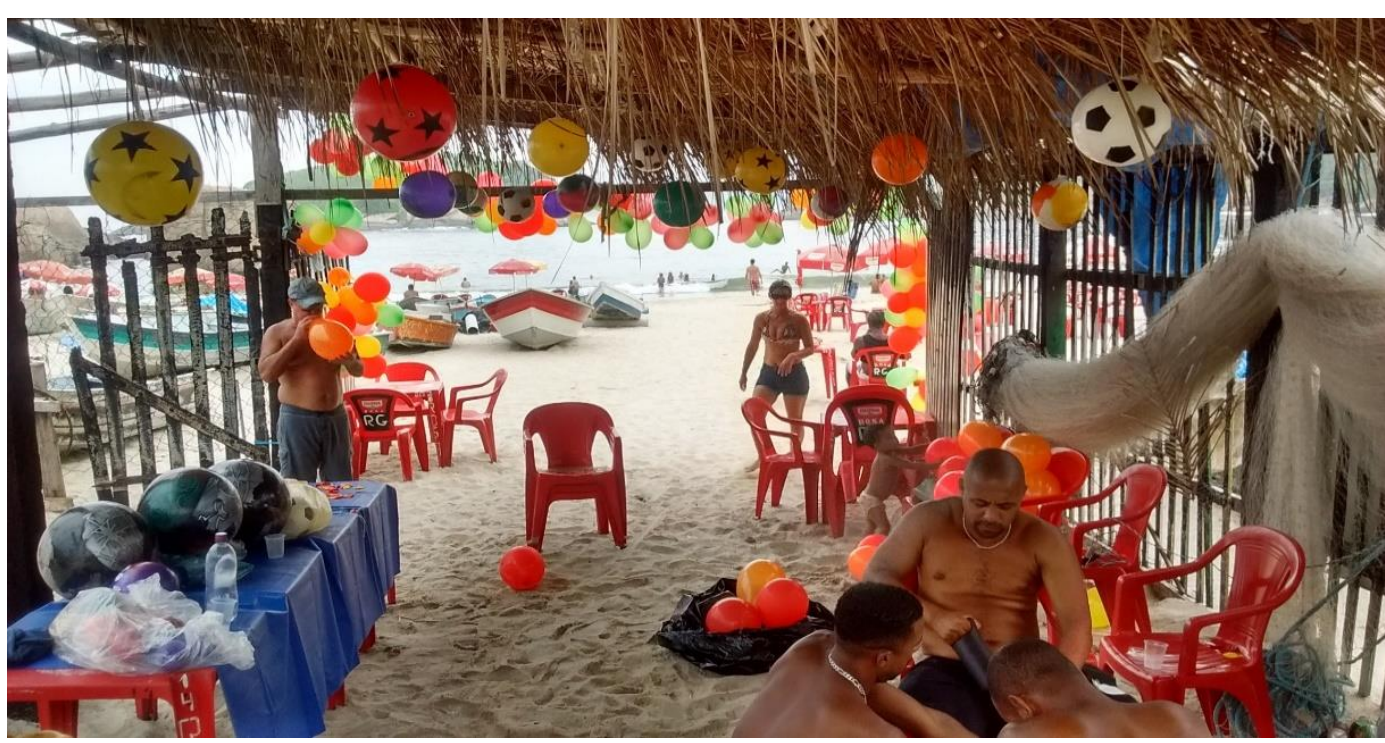

Fonte: Elaborada pelo autor.

Quem chega à praia por terra pode acessar a restinga por uma portinhola que se comunica com a área que circunda o quiosque mais próximo ao barracão. Como é fechada - apesar de não ser impossível adentrá-la -, alguns pescadores guardam ali seus instrumentos de pesca, como remos, redes e âncoras. Trata-se de uma área delimitada por vegetações, onde foram plantados - pelos próprios pescadores ou por amigos - coqueiros, arbustos e muitas mudas de plantas, como a 
aroeira, utilizada no tingimento de redes e para fins culinários, como visto acima. ${ }^{29}$

Nessa mesma área, pode-se ver um pedaço de uma proa de embarcação, utilizado como adorno, bem como um pedaço de canoa fazendo as vezes de banco. No mais, há um oratório oval de pedra - construído pela iniciativa e através do financiamento de um dono de quiosque -, dentro do qual se encontra uma estatueta de São Pedro - padroeiro dos pescadores,$-{ }^{30}$ e um oratório feito com o pedaço de uma proa, onde se encontram duas imagens de Santa Sara, ambas encontradas no lixo e restauradas. Embora utilizada mais para adornar o espaço do que para adorála, curiosamente, na cosmologia cristã, Santa Sara também está ligada ao mar: por conta da perseguição dos primeiros cristãos, ela foi colocada em um barco solto à deriva, sem remos e sem velas!

Figura 31 - Oratório com imagens de Santa Sara.

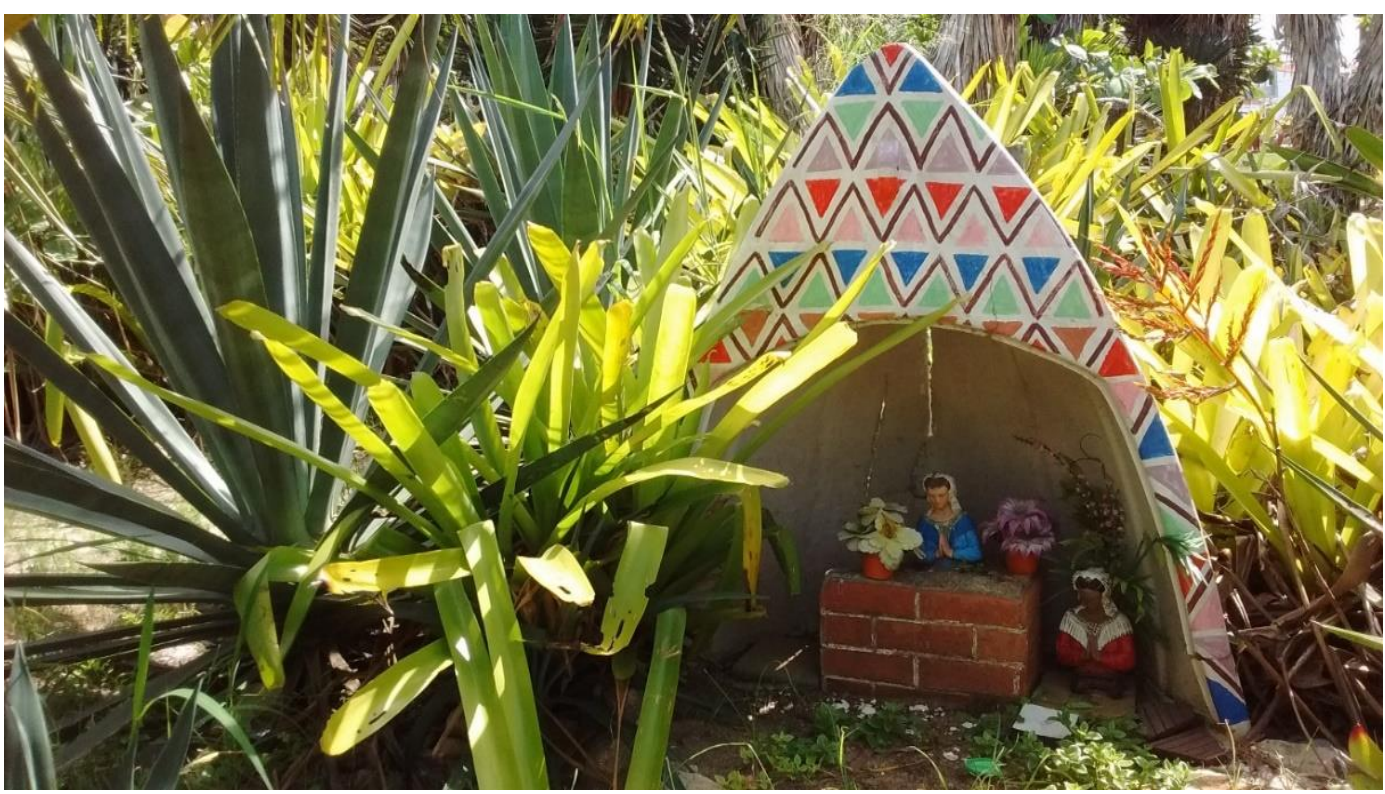

Fonte: Elaborada pelo autor.

Próximo à estatueta de São Pedro, há uma cabana, cuja estrutura é feita de madeiras e a cobertura, de palhas. Sob sua sombra pescadores e amigos fiam prosa,

\footnotetext{
${ }^{29}$ A restinga enquanto categoria local não deve ser confundida com as restingas distribuídas geograficamente ao longo do litoral brasileiro. De acordo com a Resolução n ${ }^{\circ} 07$ de 23 de julho de 1996 da CONAMA "entende-se por vegetação de restinga o conjunto das comunidades vegetais, fisionomicamente distintas, sob influência marinha e fluvio-marinha. Estas comunidades, distribuídas em mosaico, ocorrem em áreas de grande diversidade ecológica sendo consideradas comunidades edáficas por dependerem mais da natureza do solo que do clima".

${ }^{30}$ Há anos não são realizados os festejos em homenagem a São Pedro. O motivo invocado para tanto é a desunião entre os pescadores de Piratininga, diferentemente do que ocorre, segundo eles, em Itaipu.
} 
comem, dormem e observam o mar. Além disso, Cléber tem utilizado essa construção para confeccionar esteiras. No passado, estas eram produzidas no Recanto das Garças pela família de Celso, amigo de longa data de Cléber, catador de mexilhão, compositor de mão cheia e um dos que assumem os remos quando convocado. Celso ensinou-lhe a fazê-las. Os fios das esteiras são feitos com as folhas de taboas (Thypha domingensis), planta herbácea encontrada nas margens da Lagoa de Piratininga. Atualmente, porém, tem sido mais difícil encontrá-la.

A "natureza” está sempre presente no discurso e na prática de Cléber. Foi ele quem plantou boa parte da vegetação da restinga; ele também alimenta inúmeros cães que são deixados na praia, os quais passam a lhe seguir devotamente. Faz questão de manter a praia "limpa", varrendo a catando as latinhas largadas pelos banhistas. Frequentemente, ele associa os adjetivos "artesanal" e "tradicional" a uma necessária "sintonia com a natureza", ao domínio de um saber naturalístico em oposição ao saber técnico-científico: "[A pesca] é tradicional porque a gente não tem toda essa tecnologia; a gente tem que tá em sintonia com a natureza". No que diz respeito à confecção das esteiras, o discurso parece adquirir outros contornos quando lhe é incorporada a palavra "sustentabilidade":

Cléber: Isso aqui é a palavra da moda sustentabilidade. É resistência! Os caras que invadiram terreno na beira da lagoa estão desmatando tudo. Quando eu era criança via a família de Celso tirar a taboa para fazer esteiras.

Figura 32 - Cabana situada na restinga.

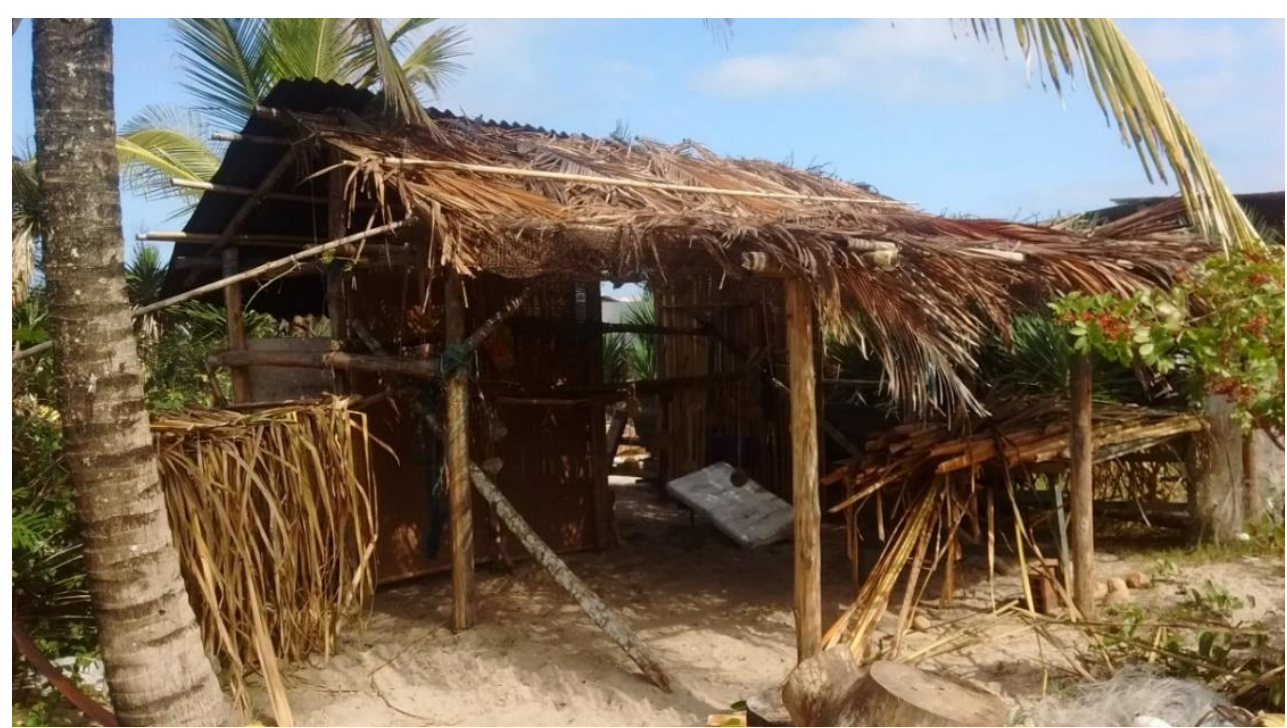

Fonte: Elaborada pelo autor. 
Apesar de ser uma área "da associação”, a restinga não é usada por todos os membros do grupo. Cléber tem um controle maior sobre o espaço, expresso tanto naquilo que é plantado quanto na disposição do mobiliário. Lá ocorreram muitas das minhas observações e das conversas que tive com pescadores e amigos. $\mathrm{Na}$ restinga, por exemplo, após um dia de pescaria bem-sucedida ou não, reúnem-se para comer peixes fritos ou pratos que levam frutos do mar; quando o lanço à sorte é feito de madrugada, serve de recolhimento; como lugar de reuniões, planeja-se festividades e transmite-se informações sobre condições meteorológicas, espécies capturadas etc.

Outro espaço de uso comum é o galpão - ao qual também se referem como barracão. É a última construção à direita de quem chega por terra e é a parte mais recuada do barracão. Trata-se de uma área aberta na frente e em uma das laterais; a outra lateral é murada com tijolos, ripas de madeira e varas de bambu. Ao fundo, onde há uma porta que dá acesso à restinga, há três "quartinhos": um com a inscrição "Argonauta", outro chamado "Fortuna" e um terceiro com uma âncora desenhada em azul. O primeiro e o segundo pertenciam a Mestre Bal e a Tinga, respectivamente, antigos mestres de companhas pretéritas, constantemente relembrados pelo grupo, seja pelos feitos ("na Semana Santa ele 'porrava' muito peixe"), seja pelo ingresso e iniciação na pesca ("foi ele quem me ensinou").

Nesse galpão, coberto com telhas, há uma mesa alta com pés de madeira, disposta verticalmente à esquerda, e sobre cujo tampo de metal limpa-se peixes e descasca-se mexilhões. Compõe a mobília uma mesa menor fabricada com o tronco de uma árvore. Embora o local por excelência da venda de peixes em Piratininga seja a beira da praia, eventualmente pode-se comprá-los nesse espaço. Do mesmo modo, utilizam-no para a realização de reuniões - como as da Resex - e para o preparo de comidas, uma vez que um dos "quartinhos" foi transformado em cozinha e, após o incêndio, na "cantina" da Rosa, esposa do Cleber.

As canoas, os barcos e as demais embarcações ficam posicionadas em frente ao barracão. Aquelas que pertencem aos pescadores mais ativos encontram-se mais próximas do mar, a fim de facilitar o deslocamento. As restantes, pertencentes a pescadores inativos (ou menos ativos), moradores e turistas, encontram-se mais próximas ao barracão. Além disso, o número de embarcações aumenta ou diminui conforme a variação sazonal da Praia de Piratininga, marcada pela alternância entre inverno e verão. 


\subsection{2.}

\section{Morfologia sazonal}

Na Praia de Piratininga, há duas divisões temporais relacionadas às atividades que envolvem à pesca e às demais atividades que ocorrem na praia: inverno e verão. À semelhança do que Kant de Lima (1997, p. 128) observou em Itaipu na década de 1970, pode-se dizer que são mais do que duas estações, pois "constituem-se em verdadeiros polos de atração de significados sociais", tendo implicações na reconfiguração do espaço da praia.

Durante os preparativos para o verão, que se inicia em meados de agosto, pescadores e barraqueiros participam de disputas que põem em questão a estrutura política então estabelecida. Muitas vezes, os envolvidos são parentes, vizinhos ou "conhecidos".

Ser dono de uma canoa tem algumas vantagens nessa disputa, uma vez que se carrega o signo da tradicionalidade. A despeito de numericamente menores, os pescadores que praticam o arrasto na modalidade lanço à sorte são mais respeitados, seja por quem pesca de rede de espera e pelos mais velhos, seja por aqueles que, mesmo de fora, conseguem ler a gramática local. No entanto, sua posição passa a ser questionada quando o "fazer comércio" aparece.

Quanto a quem vem de fora, este terá maior sucesso na ocupação de um espaço da praia de acordo com as relações de parentesco ou compadrio e as negociações políticas construídas com os pescadores. Nesse caso, pode-se dizer que o barraqueiro que consegue circular mais facilmente no interior do grupo logrará mais êxito do que aquele "apadrinhado" por um único pescador.

No verão, que coincide com o período de férias, a praia é ocupada por banhistas, vendedores ambulantes e barraqueiros durante praticamente todos os dias da semana, desde às $8 \mathrm{~h}$ da manhã até o final da tarde. Outros atores que surgem são os fiscais da Prefeitura, que tentam coibir a colocação de barracas na extensão da praia.

Durante esse período, a pescaria é praticada preferencialmente de madrugada ou nas primeiras horas da manhã (“cedinho"), a fim de que as operações de desencalhar e encalhar possam ser realizadas sem maiores empecilhos, já que, como afirmei, a área é tomada por mesas, cadeiras e barracas. Além disso, muitos banhistas jogam lixos dentro das embarcações, o que é motivo de irritação. 
Após as férias, a praia passa a ser ocupada por esses atores somente nos fins de semana e feriados. No final de março, o número de banhistas, vendedores ambulantes e barraqueiros cai drasticamente, sendo motivo de reclamação daqueles que "fazem comércio". É o início do inverno. Muitas embarcações de pessoas de fora são retiradas da frente do barracão pelos próprios donos. As disputas por espaço passam a ser mais escassas.

Figura 33 - Congestionamento de embarcações durante o verão.

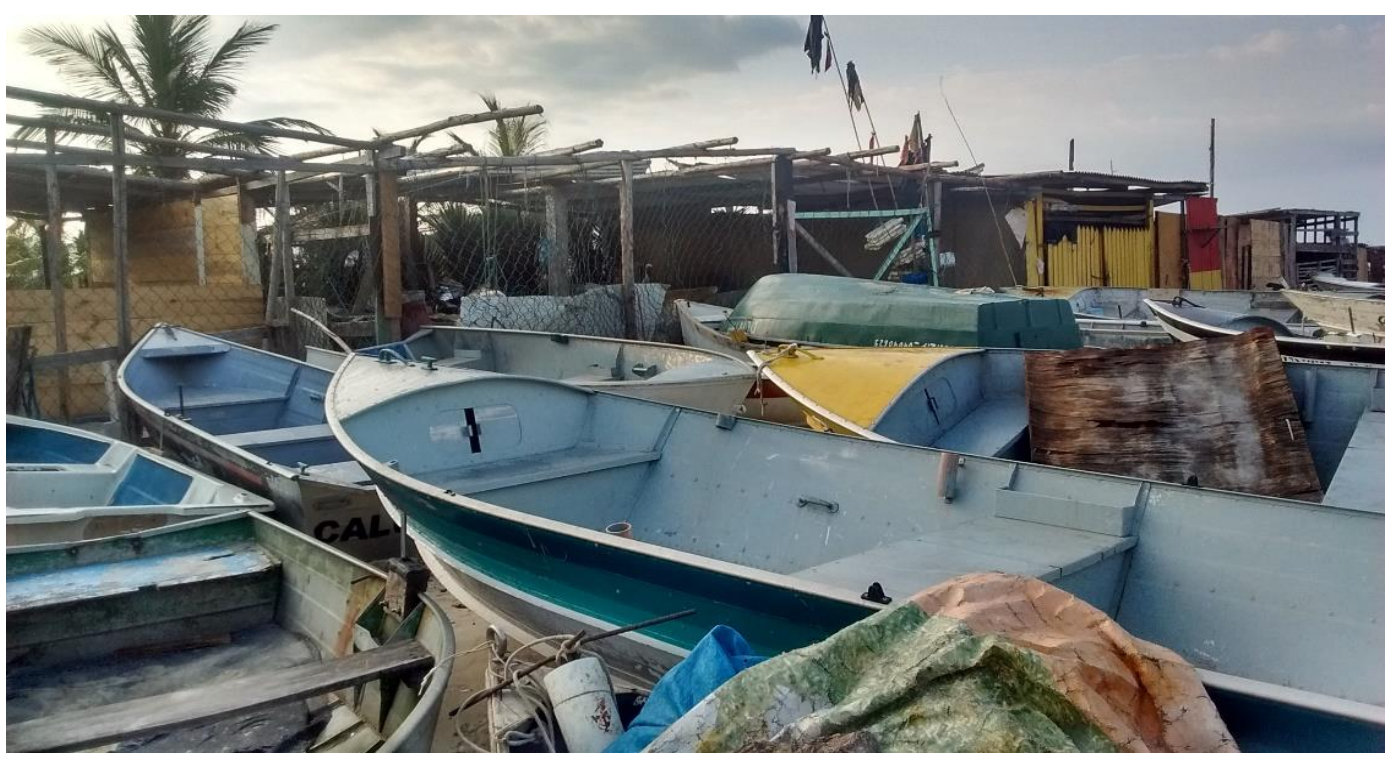

Fonte: Elaborada pelo autor.

No inverno, segundo os pescadores, permanecem na praia somente aqueles que "vivem da pesca" e que "sabem pescar".

Kiko: No inverno, com o mar agitado, realmente, têm poucos que saem. No inverno muda: são 10 pescadores no máximo - ou menos. No verão, com o mar manso, tem um monte; até quem não sabe pescar vai; tem dinheiro, compra um barco, bota aí. Quem vive da pesca mesmo perde seu espaço, porque tem muito barco. Agora, o que vai acontecer no inverno? Vai chover, vai dá água da dengue nos barcos e eles vão embora; quem pega doença de dengue é quem tá aqui no dia a dia; eles, não, não estão aqui; têm emprego fixo. Inverno aqui é dois ou três dias de mar manso. 
Trico: Eu gosto mais do inverno para pescar: é menos bagunçado, tem menos barco, menos bagunça na areia, fica mais selecionado porque a gente sabe quem vive da pesca.

Em contraste à "bagunça" do verão, o inverno "seleciona" quem "vive" ou não da pesca. O verão apresenta-se, para muitas pessoas, como uma oportunidade de se obter alguma renda, tanto para o pescador quanto para o barraqueiro. No inverno, ao contrário, as areias ficam praticamente vazias, enquanto o mar agitado repele todos aqueles que "não sabem pescar".

\subsection{3.}

\section{Disputas, tensões e "olho grande"}

Na memória vivida do grupo, a existência do barracão remonta à década de 1940 ("quando eles começaram a fazer o loteamento"). Mas é preciso ressaltar que a construção nem sempre foi a mesma. A percepção segundo a qual o barracão seria um "acampamento", condiz com a própria história do barracão, marcada por reconstruções, derrocadas e incêndios.

Na década de 1960, período de implementação de projetos urbanísticos em Niterói, a construção do barracão ficou a cargo de um tal José Salles, ${ }^{31}$ identificado por Seu Vadinho como o representante de uma companhia de loteamento que atuava em Piratininga desde a década de 1940: “O barracão de pesca começou em 1960 e pouco. O primeiro barracão quem fez aí foi o Salles, o representante da companhia de loteamento", que seria oriundo de Copacabana, no Rio de Janeiro.

De acordo com Seu Vadinho, José Salles teria sido não apenas o responsável pela construção mas, também, o "dono" do barracão: ${ }^{32}$

Seu Vadinho: Aquilo ali [o barracão] era da companhia de loteamento. O falecido Dozinho, pai de Trico, assumiu uma pescaria grande. Ele administrava a pescaria, tomava conta da pescaria e do barracão; o dono não pescava. Ele tinha casa na praia, era dono do loteamento, o José Salles.

\footnotetext{
${ }^{31}$ Infelizmente, não consegui levantar mais informações a respeito desse ator.

${ }^{32}$ Pode-se inferir que havia, entre os pescadores e Salles, uma relação de patronagem. No entanto, como não pude obter mais informações, prefiro não recair em ilações.
} 
O "primeiro barracão" consistia em duas "barraquinhas": uma aberta, de uso comum, onde eram guardados petrechos de pesca, trocava-se de roupa e resguardava-se da chuva ou do sol escaldante; e outra que pertencia apenas a um dos pescadores. Ambos os espaços eram usados e apropriados pelos donos e membros das pescarias de canoa.

$\mathrm{O}$ barracão adquiriu as dimensões e a infraestrutura atuais quando Seu Maurício, que não atua nas pescarias de arrasto, reaproveitou madeiras e telhas que estavam abandonadas no terreno de seu pai. Anos depois, em 1995, as madeiras foram trocadas para melhor conservar o espaço.

Seu Maurício: O barracão foi a gente que fez. Quando eu comecei a pescar aqui só tinha um cercadinho pequenininho ali [em frente à parte de Cléber]. Era um cercado onde Neir, tio de Trico, colocava seu caíco. Depois, Maurício Grego fez esse barraco aqui; aí, eu fiz o meu do lado.

À época, Catiquinho, Kiko, Nareba e outros pescadores ainda não haviam chegado a Piratininga; o número de pessoas que se dedicava à pesca era bem reduzido. O único que pescava de rede alta era Seu Maurício, que só pescava com esse tipo de rede. Cléber pescava de arrastão; Maurício Grego pescava de linha, e Trico "pescava com a redinha dele”, nas palavras de Seu Maurício. ${ }^{33}$ Em relação a uma "época de ouro" da pesca - sobretudo, da tainha -, Seu Maurício acredita que antigamente era muito melhor:

Seu Maurício: Eu não pescava nem com corvineira. A pescaria era sempre isto aí: saía à noite e de manhã estava em Itaipu vendendo peixe. Hoje você pode pescar de rede alta, de corvineira, que não tem mais peixe nenhum.

O relato anterior e o que se segue dão conta de uma dinâmica peculiar ao local, uma vez que a reconfiguração do espaço está condicionada à articulação e, em alguns momentos, à "retomada" da atividade pesqueira (do "foco de pesca"):

\footnotetext{
${ }^{33}$ As datas, os períodos, os momentos e as pessoas nem sempre condizem entre os discursos dos pescadores.
} 
Cléber: A pesca foi ficando fraca, o pessoal foi migrando para Itaipu, onde tinha mais recursos de mão de obra, pessoa para pescar. Chegou uma época que eu fiquei sozinho, não tinha mais ninguém. E eu que tinha visto isso aqui em pleno vapor, vi que não tinha mais nada. Fiquei muito triste por ter acabado o foco de pesca, e ai eu permaneci. E ai foi chegando um por um, devagar: "Vou deixar um barquinho aqui". Até que chegou um grupo, uma quantidade que já dava pra gente se agregar aqui. Aí eu fui e remontei o barracão de novo e fui fazendo devagarzinho, de acordo com quem ia chegando. Fiquei feliz porque voltou de novo a pesca.

Mas o arrefecimento e a retomada do "foco de pesca" não são os únicos fatores a influenciar as reconfigurações do espaço. A trajetória do barracão também está associada a disputas de interesses e a constante reconstrução do barracão.

A categoria conflito é utilizada frequentemente pelos pescadores. Os relatos aflitivos do Cléber invocam-na em várias dimensões. Externamente, o conflito se dá com aqueles que discordam da maneira pela qual ele vem ocupando aquele espaço, tendo em vista que sua esposa "faz comércio". Nesse caso, tanto os próprios pescadores quanto os barraqueiros fazem parte da contenda; em relação a estes últimos, as disputas se agravam com a aproximação do verão, período durante o qual "todo mundo quer garantir o seu [dinheiro]". Para Cléber, contudo, essa ocupação é necessária à manutenção do "núcleo de pesca" ("esse espaço é da associação!"); não fossem as mesas e barracas de sua esposa fazendo as vezes de "barreira de contenção", impedindo o avanço dos barraqueiros, ficaria impossibilitado de deslocar suas canoas. No mar, o conflito ocorre quando as redes de espera são colocadas de modo a impossibilitar a pesca de canoa. Não obstante, tem "conflito interno" consigo mesmo, pois diz que não consegue deixar de ajudar aqueles que, provavelmente, entrarão em conflito com ele.

Mas, como descrevi no capítulo anterior, os embates não estão restritos a esse ator. Durante o trabalho de campo, presenciei disputas de diferentes naturezas entre pescadores e barraqueiros - principalmente quando o verão se aproxima -, entre pescadores que exercem uma mesma estratégia de captura e entre barraqueiros e barraqueiros. Por exemplo: quando as redes são colocadas em pontos “impróprios”, como canais e portos ou próximo às formações rochosas; quando há uma concentração de pescadores em um único pesqueiro; quando se põe a rede em 
um pesqueiro considerado "de linha"; quando se tem "olho grande"; quando se toma "emprestado" algum petrecho sem avisar ao dono.

Quando dei início ao meu trabalho de campo, notei que as tensões "em terra" acentuaram-se após o incêndio. Pouquíssimos pescadores mobilizaram-se para retirar as cinzas e os escombros. Novamente, foi Cléber quem levantou o "acampamento". Nos bastidores, à boca miúda, suspeita-se que o fogo tenha sido provocado por pescadores locais. Embriagados, eles mesmos teriam revelado a autoria, motivados pela insatisfação com a maneira pela qual o espaço era utilizado. Mas ninguém os acusou publicamente; eles continuam a fazer parte do grupo e a frequentar os mesmos espaços de socialização. Para quem perdeu seus bens materiais, tudo não passou de inveja e "olho grande".

A propósito, como o leitor observou, a categoria olho grande é utilizada frequentemente pelos membros do grupo. Trata-se de uma qualidade atribuída às seguintes pessoas e circunstâncias: à quem não quer ter um companheiro de pesca para não ter que dividir o quinhão; à quem não revela pesqueiros onde está "dando" peixe ou não mostra o que foi capturado ("cheio de segredo"); à quem não distribui o pescado, seja com alguém que contribuiu nas operações de encalhar e desencalhar a embarcação, seja com alguém que pediu um peixe "para almoçar"; à quem pesca eventualmente e apenas após constatar que alguém "se deu bem"; à quem utiliza petrechos "não-tradicionais"; à quem "faz comércio" na praia.

Cléber sustenta que o conflito existente na praia ocorre em função do olho grande. Após reerguer o barracão ("ninguém veio ajudar"), seu objetivo era manter a divisão anterior do espaço. Todavia, Josi, "de olho grande", apropriou-se de uma parte que antes cabia a mais de oitos membros do grupo. Apesar de permitir que outras pessoas armazenem ali seus petrechos, tem utilizado esse segmento do barracão para "fazer comércio", trazendo, inclusive, um "pessoal de fora" ("pessoal do Cafubá, que ninguém conhece"), o que tem gerado mais intrigas e discórdias. Não obstante, quando mergulha para catar mexilhão, faz uso de um compressor (instrumento "não-tradicional"), que lhe possibilita recolher uma quantidade muito superior daquele molusco, se comparado com quem mergulha de apneia. 


\section{3.}

\section{Muitos sentidos, pouco consenso}

Sentado no bordo de uma embarcação, Catiquinho contou-me, orgulhoso, que, quando entra o verão, seu barco é frequentemente utilizado pelos banhistas para figurar em fotografias. A paisagem de Piratininga já foi televisionada: duas novelas da Rede Globo (Andando nas Nuvens e Da Cor do Pecado) e um videoclipe do grupo de forró Falamansa utilizaram a Prainha e o barracão como cenários. Alguns pescadores, inclusive, participaram das gravações como figurantes. De acordo com Cléber, isso somente foi possível graças ao aspecto "rústico" do barracão.

Figura 34 - Trico consertando uma rede de tarrafa na lateral do barracão.

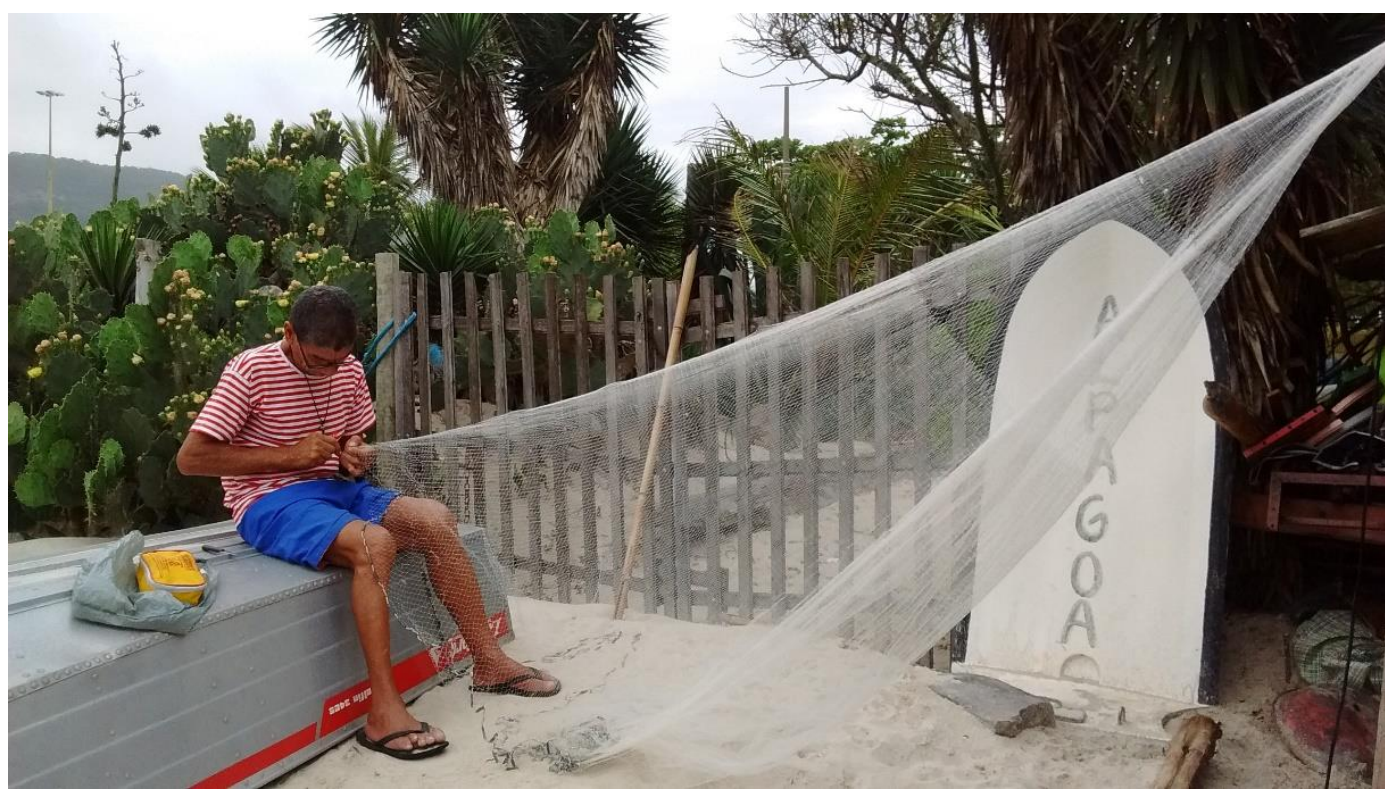

Fonte: Elaborada pelo autor.

Na visão de Cléber, o barracão é um “espaço de pesca da pescaria artesanal tradicional e comunitária", cuja legitimidade para ocupá-lo encontra-se na permanência das canoas de "um tronco só" na praia; são estas embarcações que teriam "o direito ao espaço", devido ao seu caráter originário. 
Cléber: O começo é a canoa, fusão do escravo com português. Em Portugal ainda se pratica essa pescaria. ${ }^{34}$ Foi essa pesca que deu origem à Marinha; todas as regras de navegação estão na canoa.

Cléber: Eles [os demais pescadores] têm que proteger as canoas, já que elas é que têm o direito ao espaço, não me condenar. É por causa das canoas que nós temos direitos a esse espaço. Porque [no passado] não havia outras pescarias, só tinha canoa; não tinha caíco com rede. Não existia plástico; o plástico veio há pouco tempo, quando saiu rede plástico para você comprar ali na loja.

Cléber: $O$ rancho era das canoas. Agora, se cada uma dessas outras pessoas que têm barquinho quiserem um rancho igual das canoas... Por que razão? Se as redes são leves. Tudo bem que hoje há uma tralha, um equipamento de pesca... Hoje, todos têm direito, porque eu quero que o Catiquinho tenha onde guardar o lugarzinho dele, eu quero que o Rogério tenha como proteger o material dele que é tão frágil para ele pescar, eu quero que eles tenham sombra para consertar o barco, eu quero que eles tenham tudo, já que eles também entraram na linha de artesanal porque é rude, as coisas ali são rudes. Pelo tempo que eu tô aqui pescando com eles eu vi que ninguém evoluiu em aspecto nenhum; têm uns que nem sabem fazer seu próprio equipamento ainda, depende de pagar o outro. Todos têm direito mas não no aspecto da razão. A razão a gente tem que buscar a fundo, porque a briga que eu tô aqui até hoje é pelo espaço de pesca da pescaria artesanal tradicional e comunitária... E hoje eu nem posso pescar! Fui eu que ensinei Nareba a pescar, fui eu que ensinei todos esses malucos a pescar e hoje eu não posso com o tipo de pesca que eu faço, porque eles não deixam, colocam a rede ali. Eu tenho um limite, eu tenho regras a cumprir naquela pescaria.

Quando criança, Cléber se recorda que somente dois pescadores possuíam canoas; os demais assumiam outras funções na pesca. Eram eles que ocupavam as duas "barraquinhas" descritas acima. As pescarias de rede de espera são recentes

\footnotetext{
${ }^{34}$ De fato, como demostrou Colaço (2012), há muitos pontos de convergência entre as pescas de canoa realizadas no Brasil e em Portugal.
} 
("não tinha plástico antigamente"), o que não daria direito àqueles que a exercem de reivindicar um espaço na praia. Para ele, o fato de ter sucedido os mais antigos, de ter permanecido na praia e de ter construído praticamente sozinho o "acampamento" lhe coloca numa posição diferenciada dos demais.

Cléber: Eu tenho que ocupar o espaço para garantir a coletividade, para garantir as gerações futuras, porque essa aí não deu.

Não obstante, ele sustenta que o barracão deve consistir em uma construção de aspecto "rústico" e "artesanal", que seja facilmente removível (como um “acampamento"), não pode ser fixa, uma vez que "os pescadores têm que se adaptar como os bichos na areia. Se o mar vier, leva tudo!". Do mesmo modo, além de prevenir possíveis intempéries naturais, o barracão não deve ser fixo porque, sendo um "espaço público", é necessário "se adequar às regras" prescritas pelo Estado, a exemplo das normas ambientais e de ordenamento urbano: "Nós temos que nos adaptar como quem mora perto de um vulcão".

Apesar de atrelar a existência do barracão à continuidade da pesca de canoa, o discurso e a prática de Cléber possuem algumas contradições, as quais são questionadas por alguns pescadores de rede de espera e por barraqueiros. Isso porque, além de ocupar o maior espaço do barracão, Rosa e, atualmente, seu irmão Alexandre "fazem comércio" no local, isto é, eles têm uma "cantina" na praia (ou "bar/restaurante", segundo os discordantes).

Figura 35 - Cantina situada no barracão de pesca.

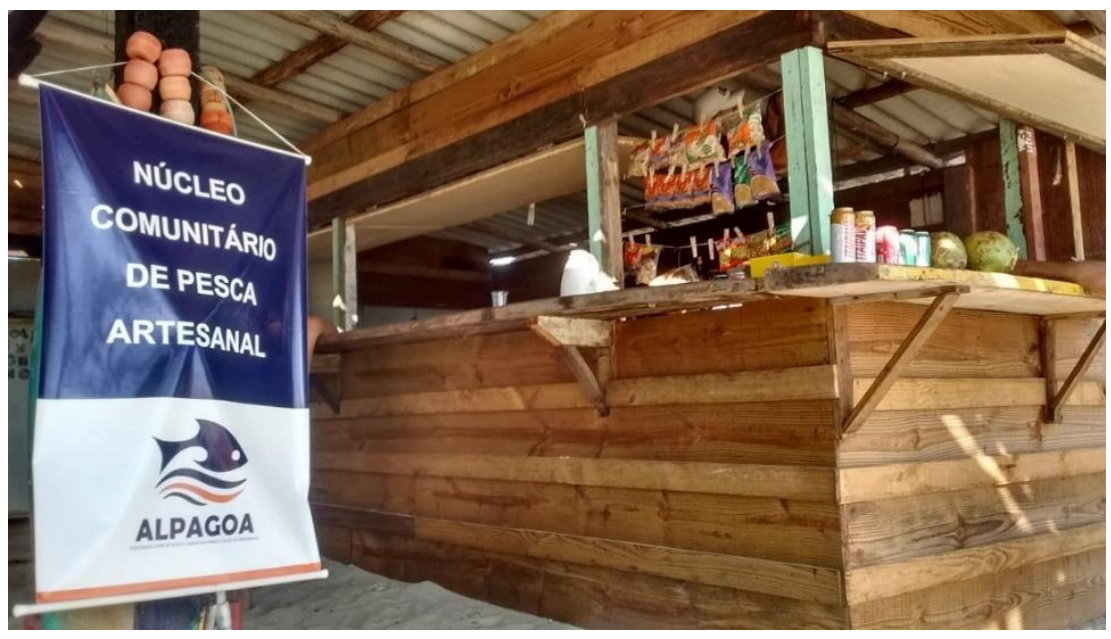

Fonte: Elaborada pelo autor. 
No que diz respeito à ocupação do trecho maior, Cléber a justifica pelo fato de ter sido ele o responsável pela construção do atual barracão. Como não teve a ajuda de quase ninguém - e "para não ser tirado de otário" -, ocupou a maior extensão. De acordo com ele, ao erguê-lo, tinha como objetivo que o grupo dispusesse de um espaço onde fosse possível guardar embarcações e petrechos, assim como trabalhar na confecção e remendos das redes. Além disso, pretendia "organizar a colônia de Piratininga". ${ }^{35}$ Para tanto, realizou a seguinte distribuição, da esquerda para a direita (de quem vem do mar), respectivamente: 1) segmento maior ocupado por Cléber; 2) segmento ocupado por Seu Maurício, Pelicano e Gringo; 3) por fim, no último segmento, havia quatro "quartos" na parede direita, dispostos lado a lado, que eram divididos da seguinte maneira: no primeiro, ficavam Kiko, Catiquinho, Trico e Alexandre; no segundo, Nareba (que não tinha barco na época) e Carlinhos (que é mergulhador e morador do Cafubá); no terceiro, Josi e Joel; e os garis que limpavam a praia ficavam no último "quarto". $\mathrm{Na}$ frente do terceiro segmento, com uma largura de aproximadamente $4 \mathrm{~m}$, havia uma porteira, e as portas dos "quartos" eram fechadas com cadeados - o que não impediu que algumas vezes tenham sido arrombados.

Figura 36 - Desenho do barracão antes do incêndio.

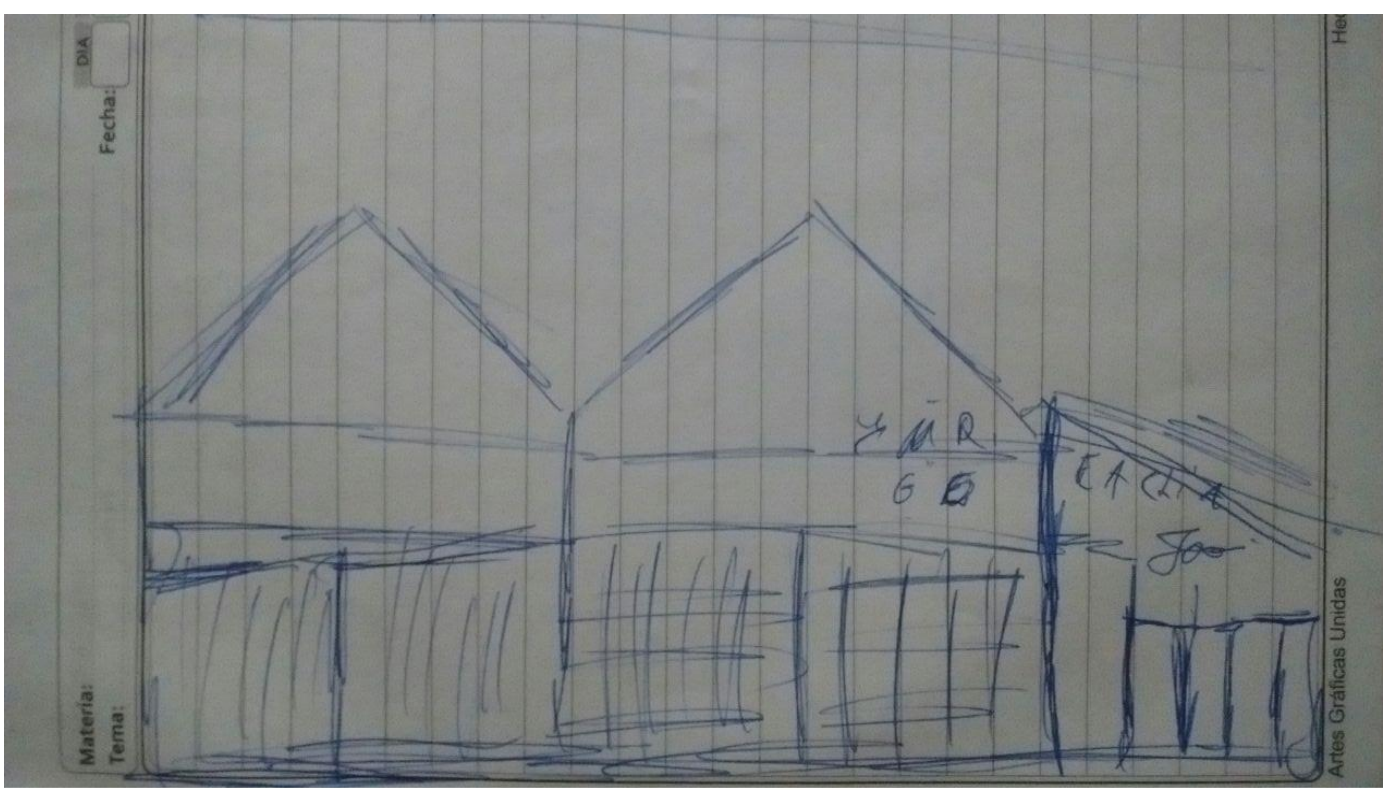

Fonte: Elaborada por Cléber.

\footnotetext{
35 A categoria colônia, nesse caso, refere-se ao núcleo de pescadores; não às colônias de pesca historicamente ligadas às ações do Estado.
} 
A partir dos relatos dos envolvidos na partilha, pode-se dizer que o critério utilizado na divisão dizia respeito ao reconhecimento de quem era ou não pescador e de quem possuía petrechos e embarcações que justificassem a necessidade de se ocupar um segmento do barracão. A partir das observações realizadas em campo, entretanto, não se pode perder de vista que as alianças políticas, os vínculos parentais e os laços de reciprocidade também exerceram forte influência nesse processo. Da mesma forma, cada parte foi atribuída a um subgrupo, constituído quer pelas relações de afinidade ou parentesco, quer pela arte de pesca praticada. Mas, a despeito de tal segmentação, como afirmei acima, nunca presenciei alguém falar "meu barracão".

Em relação à segunda controvérsia, "fazer comércio" na praia, Cléber utiliza a manutenção da "pesca tradicional" como justificativa. Para ele, a existência da “cantina" é necessária à manutenção do "núcleo de pesca", tendo em vista que, não fossem as mesas e barracas de seus familiares fazendo as vezes de "barreira de contenção" e impedindo o avanço dos barraqueiros, ficaria impossibilitado de deslocar suas canoas.

Cléber: Quem não quer ficar na beira da praia com o seu comércio? Mas não pode ocupar tanto espaço público, tem que ter um controle.$$
* * *
$$

Cléber: Todos aqueles barracões que você vê em Itaipu que fizeram restaurante partiram do princípio de que, quando ficava ruim a pescaria, o cara do barracão que tinha sua canoa vendia e fazia um restaurante. Depois, o outro não podia subir com a canoa porque o cara colocou mesa e cadeira e, agora, é restaurante. Foi por isso que deu todo aquele problema em Itaipu, aquela barracada na beira da praia... É proibido fazer construção de alvenaria dentro da areia da praia. Aqui a gente usava isso como argumento para permanecer. Seu Geraldo ${ }^{36}$ ia na Prefeitura e falava: "Tá bom, nós vamos tirar a cantina da praia. Mas você tem como tirar aquele monte lá de Itaipu?".
\end{abstract}

\footnotetext{
${ }^{36}$ Seu Geraldo era um amigo dos pescadores e foi um dos responsáveis pela fundação da associação de pesca.
} 
Cléber: Em toda praia, em todo Nordeste, até mesmo em Copacabana, em todo canto o pescador dá o seu jeito; sobrevive na beira da praia, vende seu peixe. Você vive ali, você é dali, por que você não pode aproveitar a temporada? Os outros podem, todo mundo pode... Se é isso que dá a tradição do local.

Embora eu estivesse mais próximo do Cléber, o fato é que ele sempre me incentivou a ouvir os demais pescadores. Eu era considerado por ele como alguém "neutro" (sem “conflito" com ninguém) e, portanto, capaz de "fazer a ponte" entre os diferentes contendores: "Você tem que ouvir esses caras para saber o que eles pensam dessa porra. Eu já falei o que eu penso, espero que você tenha entendido", disse-me.

Nesse sentido, durante todo o trabalho de campo, mantive um bom relacionamento com a maioria dos pescadores; inclusive com quem era classificado como "olho grande". O auxílio que dei a eles por conta da regularização da associação também contribuiu para isso. ${ }^{37}$ Certa vez, por exemplo, fui convidar Josi para participar de uma reunião. Na ocasião, seu amigo Figueiredo preparava um risoto de polvo. Ambos me convidaram para almoçar. Aceitei o convite. Experimentei uma cachaça que me foi oferecida, compartilhei do mesmo prato e conversei com eles durante horas. Evidentemente, um dos assuntos girou em torno do barracão.

De acordo com Josi, diferentemente de alguns pescadores, ele "é pescador profissional", porque está devidamente registrado: "Pescador que é pescador tem que ter carteira. Se tiver carteira tem direito ao espaço", afirmou. Sob essa perspectiva, se Cléber utiliza as canoas como fundamento para a ocupação do barracão, Josi tem na carteira de pesca a fonte legitimadora do direito de apropriação daquele espaço.

Em conformidade com Josi, como ele tem um quadriciclo (uma "aranha"), não teria necessidade de espaço no barracão, já que poderia trazer e levar seus equipamentos para casa. No entanto, um pouco antes do incêndio, deixou alguns objetos no quartinho que correspondia à Companhia de Limpeza de Niterói (CLIN). Disse que, depois do incêndio, chamou alguns pescadores para ajudá-lo a

\footnotetext{
${ }^{37}$ Do mesmo modo, Izabela Fernandes teve um papel importante, auxiliando juridicamente na
} constituição de uma nova associação. 
reconstruir o espaço; mas somente pôde contar com a contribuição de conhecidos do Cafubá. Depois, todos passaram a dizer que ele tomou o espaço.

A despeito das acusações dos outros pescadores, argumentou que o barracão é aberto a todos:

Josi: Isso aqui é igual a coração de mãe, quem quiser vir aqui comer, guardar remo, pode vir. Não é meu; é meu porque alguém tem que colocar ordem, deixar tudo limpo e organizado.

Ao lado da parte que ocupa, há segmentos (barracos) ocupados por dois barraqueiros (um deles se diz "filho de pescador", mas utiliza o espaço para guardar mesas e cadeiras), por um pescador e por outro barraqueiro, respectivamente. Todos são moradores de Piratininga e mantêm, com alguns pescadores, laços de parentesco e/ou vizinhança. Igualmente, os guarda-vidas da praia também ocupam uma parte do barracão, além de terem construído o posto ao qual me referi nos capítulos anteriores.

Para os pescadores que ficaram de fora da partilha ou que não se apropriaram de nenhum espaço, o barracão tem a aparência de uma "favela", categoria carregada com uma conotação negativa:

Valmir: Parece uma favela. Não tem mais pescador em Piratininga. Aqui já foi um lugar bom. Hoje, só eu e uns poucos que pescam. Ainda bem que já vou me aposentar. Eu ainda pesco porque preciso comer e beber.$$
* * *
$$

Nareba: Tá parecendo uma favela. Barraca em beira de praia tem que ser bonitinha e organizada. Isso tudo aqui [apontando para os barracos] é comércio; não tem nada a ver com pescaria. Pescador tem que tá aqui e colocar os equipamentos no mar; não é para ficar esperando o verão para vender comida e bebida. O caras fizeram uma garagem para barco. Parece carro!
\end{abstract}

Certa vez, na beira da praia, enquanto limpavam peixes, Rogério e Celso conversavam. O primeiro disse que deveria ter comprado barracas e cadeiras 
porque "esse negócio de pescaria não dá mais", enquanto o segundo lhe respondeu: "Tem mais barco aqui do que peixe".

Em uma sexta-feira, estávamos Cléber, Maia, Tatá, Mimico e eu na restinga planejando uma ida à Ilha do Veado. Era um momento de descontração. De repente, contudo, a conversa foi interrompida pelos gritos da Rosa. Flavão, um dos barraqueiros, pretendia colocar mesas e cadeiras na parte da frente do barracão onde as canoas estavam posicionadas. De acordo com ele, um dos pescadores vendeulhe o espaço. Houve apenas uma discussão verbal, mas Flavão não conseguiu por suas barracas - dias antes, participara de uma disputa infrutífera com outros barraqueiros.

Indignado, Cléber relatou que, quando chega o verão, essas disputas aumentam. Disse que estava ali há muito tempo e que, se não fossem as barracas e cadeiras colocadas pela esposa, não haveria lugar para passar com as canoas. No inverno, diferentemente, "ninguém quer ficar na praia". Além disso, afirmou que conversaria com o suposto "vendedor" do espaço para que ele desfizesse o negócio.

Dias depois, pude presenciar a conversa entre ambos. Indagado sobre a "venda", o suposto negociante disse que estavam usando o nome dele e que não queria "nem saber dessa confusão"; passaria a pescar no Praião, pois, quando chegasse o verão, a praia ficaria “insuportável”. Em tom cordial, Cléber lhe disse que, caso os barraqueiros avançassem, ele ficaria impossibilitado de pescar.

No "olho do furacão", passei a trabalhar com a hipótese segundo a qual aqueles conflitos seriam acentuados durante o verão. Mas isso não aconteceu. Ao contrário, nesse período, houve uma concertação entre os atores envolvidos, o que não quer dizer que o conflito tenha findado. Conforme Cléber, "todo mundo conseguiu o que queria e, agora, todo mundo está com medo da Prefeitura".

De fato, durante o verão, presenciei uma conversa entre Cléber e Flavão, que, aliás, esteve presente em uma festa de aniversário celebrada no barracão: "Independente de qualquer coisa, nós somos amigos", disse-lhe Cléber. Para ele, tudo aquilo não passava de "intrigas". Deram-se as mãos. No ano seguinte, entretanto, ocorreram novas (velhas) disputas em função dos usos e apropriações daquele espaço. 


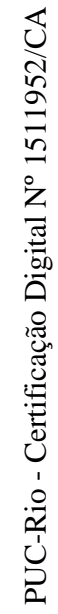


SEGUNDA PARTE:

COMPREENDER 
Um dos dramas do mundo contemporâneo é que a Terra foi "desnaturada", e o homem só pode vê-la através de suas medidas e de seus cálculos, em lugar de deixar-se decifrar sua escrita sóbria e vívida

(DARDEL, 2011, p. 96)

\section{5.}

\section{Quem define o quê, quando, onde e como?}

Esta segunda parte desta dissertação tentará responder algumas questões que elaborei no decorrer do trabalho de campo, quais sejam: qual é ou quais são os objetos em disputa em Piratininga? Quem são os atores envolvidos e quais são os seus interesses? Como esses atores percebem, valorizam e ocupam os espaços da praia? Como são construídas as relações de poder na praia?

Provavelmente, você, leitor, produziu indagações semelhantes ou completamente diferentes das minhas. Em ambas as hipóteses, creio ter logrado êxito ao optar por apresentá-lo, de antemão, o material da pesquisa empírica. Isso poderá gerar novas reflexões e trabalhos a respeito do que foi descrito acima.

Agora, com o auxílio de um aporte teórico e conceitual, nos esforçaremos em compreender alguns pontos que, a meu ver, são relevantes. Proponho apenas a abertura de algumas janelas; mas outros horizontes podem ser descortinados.

Conforme descrito acima, o conflito na Praia de Piratininga compreende as disputas pelos espaços da praia. Os adversários são pescadores de rede de arrasto, pescadores de rede de espera - e outras artes - e barraqueiros. Há brigas pela forma de uso dos portos - no mar ou na lagoa -, pelo uso dos pesqueiros, pelos usos e apropriações do barracão de pesca. Ao olhar para esse conjunto de disputas como um conflito, tentarei entender, portanto, como as ações e a existência dos indivíduos que se encontram em contendas afetam-se mutuamente. 


\section{1 .}

\section{Espaços, lugares e visões de mundo}

Para que possamos compreender o objeto em disputa na Praia de Piratininga, procederei a uma distinção entre espaço e lugar, o que tem sido feito por alguns geógrafos mais preocupados com os rumos que as sociedades humanas têm tomado, principalmente no período após a Segunda Guerra Mundial (1939-1945).

Um deles é o francês Eric Dardel, que escreveu L'homme et la Terre: nature de la réalité géographique, uma pequena, porém grandiosa obra publicada em 1952. Apesar de ter sido praticamente negligenciado à época, esse livro foi resgatado por geógrafos canadenses e estadunidenses entre os anos 1960 e 1970, tendo servido de inspiração para a formação da chamada Geografia Humanista (MARANDOLA JR., 2011, p. XII).

A preocupação do autor é mostrar, através de exemplos recolhidos de diferentes fontes - como escritos literários, filosóficos e antropológicos -, como os seres humanos qualificam os espaços geográficos em situações concretas, ou seja, como a realidade só é geográfica para o homem (DARDEL, 2011, p. 8). Nesse sentido, o "espaço puro do geógrafo" não se confunde com o "espaço abstrato do geômetra". Não se trata, portanto, de uma "coisa" indiferente, vazia de significados, mas, sim, de espaços imaginados e experimentados por nós.

Igualmente imaginário é o fato de que, nas relações indicadas por habitar, construir, cultivar, circular, a Terra é experimentada como base. Não somente ponto de apoio espacial e suporte material, mas condição de toda "posição" da existência, de toda ação de assentar e de se estabelecer (de poser et de reposer) (DARDEL, 2011, p. 40).

Daí o conceito de geograficidade, que expressa a noção do ser-e-estar-nomundo. O espaço material (telúrico, aquático, aéreo, construído etc.) pode "acolher" ou "ameaçar" a liberdade humana. Pode ser "belo" ou "feio", "salubre" ou “insalubre”, "retangular" ou “circular”. Podemos amá-lo, detestá-lo ou, até mesmo, sermos indiferentes. Por outro lado, as imagens que produzimos e a maneira pela qual experimentamos a Terra não excluem o fato de também sermos agenciados pelo ambiente geográfico, sofrendo a influência do clima, do relevo, do meio vegetal (DARDEL, 2011, p. 9). 
Esse argumento coincide com aquilo que Durkheim e Mauss já haviam afirmado no início do século XX, isto é, que "ideias tão abstratas quanto as de tempo e de espaço estão, em cada momento de sua história, em relação estreita com a relação social correspondente" (DURKHEIM; MAUSS, 1981, p. 203), em outras palavras, "a classificação das coisas reproduz a classificação dos homens" (Idem, p. 184). Ao se debruçarem sobre o estudo das representações coletivas, eles notaram que “(...) uma espécie de coisas não é simples objeto de conhecimento, mas corresponde antes de mais nada a uma certa atitude sentimental" (Idem, p. 201). As coisas podem ser "sagradas" ou "profanas"; "puras" ou "impuras"; "amigas" ou "inimigas"; "favoráveis" ou "desfavoráveis". O mesmo vale para o espaço, diferente em cada região: "É que cada região tem seu valor afetivo próprio".

Em seu já citado ensaio sobre os esquimós, Mauss observou a influência das variações sazonais na morfologia social (MAUSS, 2013, p. 425). Na Praia de Piratininga, como vimos, há duas divisões temporais relacionadas às atividades que envolvem à pesca e às demais atividades que ocorrem na praia: inverno e verão. Essa alternância sazonal tem implicações na reconfiguração do espaço. Se no verão há uma alta densidade demográfica, no inverno a praia assemelha-se a uma pintura de paisagem, com pouquíssimas personagens. No verão há mais embarcações nas areias do que no inverno. As disputas pelo espaço são mais escassas no inverno, se comparadas com o que ocorre no verão. De certa forma, o inverno representa o período em que a praia é "lugar de pescador".

Se o pescador encontra-se na praia o ano inteiro, mesmo que atualmente não permaneça por horas a fio - como era de costume no passado -, o barraqueiro ocupa aquele espaço sazonalmente, de maneira temporária e com um único objetivo: “Conseguir o seu [dinheiro]". Diferentemente, a dimensão econômica é apenas umas das tantas dimensões para as quais os pescadores se voltam em sua relação com a praia. É na praia que ocorrem festividades, reuniões políticas, troca de informações, aprendizados, brigas, bebedeiras e muitas outras experiências coletivas.

Ora, quando assentamos nossa existência em um determinado espaço geográfico, passamos a transformá-lo em um lugar, dotado de sentidos, valores e experimentações. Nas palavras de Dardel, 
Antes de toda escolha, existe esse "lugar" que não pudemos escolher, onde ocorre a "fundação" de nossa existência terrestre e de nossa condição humana. Podemos mudar de lugar, nos despojarmos, mas ainda é a procura de um lugar; nos é necessária uma base para assentar o Ser e realizar nossas possibilidades, um aqui de onde se descobre o mundo, um lá para onde nós iremos (DARDEL, 2011, p. 41).

Dessa forma, o lugar distingue-se do espaço pela presença de uma topofilia, conceito cunhado pelo geógrafo sino-americano Yi-Fu Tuan, um dos responsáveis pelo reconhecimento e divulgação da obra de Dardel. A palavra topofilia pode ser definida como "todos os laços afetivos dos seres humanos com o meio ambiente material” (TUAN, 2012, p. 135-136). Em conformidade com Tuan,

A resposta ao meio ambiente pode ser basicamente estética: em seguida, pode variar do efêmero prazer que se tem de uma vista, até a sensação de beleza, igualmente fugaz, mas muito mais intensa, que é subitamente revelada. A resposta pode ser tátil: o deleite ao sentir o ar, água, terra. Mais permanentes e mais difíceis de expressar são sentimentos que temos para com um lugar, por ser o lar, o locus de reminiscências e o meio de se ganhar a vida (Idem, p. 136).

Pensemos nas inúmeras respostas ambientais que pudemos observar em relação à Praia de Piratininga. Reflexivamente, disse que fiquei surpreendido com a beleza da Prainha: um quadro composto por duas formações rochosas, uma ilha, um mar pintado em tons de verde e um horizonte, de onde se pode ver a cidade do Rio de Janeiro e cujas nuvens, ao entardecer, dão a impressão de uma falsa cordilheira. ${ }^{38}$ É agradável mergulhar naquelas águas, principalmente porque a pequena enseada protege aqueles que a experimentam da força das ondas que atingem mais frequentemente o Praião. Temos aí uma resposta estética; talvez a mesma reação tida por muitas turistas que chegam à praia, tiram selfs, bebem suas cervejas e voltam para os seus cotidianos.

Mas a resposta dada pelos pescadores, que vivem e ganham a vida em Piratininga, parece ser de outra ordem. Para eles, aquilo é mais do que um espaço. Cada pedra tem um nome, assim como cada espécie de peixe. As marés e as luas são classificadas. O tempo pode ser "bom" ou "ruim". Suas embarcações e petrechos não são meros objetos, pois carregam significados e histórias. Nas paredes da memória, as lembranças sobre acontecimentos, feitos e pessoas que

\footnotetext{
${ }^{38}$ Estas “cordilheiras" me foram descritas por Ronaldo Lobão.
} 
passaram pelo bairro estão vivas e presentes. Para os pescadores, aquela praia é o lugar deles por excelência, porque é onde e com o qual mantêm relações afetivas.

Um lugar, portanto, não está reduzido à lógica mercantil, como pretendia o barraqueiro ao tentar negociar a venda da área em frente ao barracão. Essa postura em relação ao espaço aproxima-se daquilo que Simmel identificou, na metrópole moderna dominada pelo dinheiro, como atitude prosaicista ${ }^{39}$ que se manifesta na redução da vida social em fórmulas matemáticas, transformando o mundo em um problema aritmético, conforme o ideal da Ciência Natural (SIMMEL, 1976, p. 14). Radicalmente oposta, portanto, à atitude sentimental (DURKHEIM; MAUSS, 1981, p. 201), às relações afetivas que mantemos com os lugares.

À topofilia estão ligadas outras palavras-chave cujos significados se superpõem: a) percepção: a resposta que os nossos sentidos dão aos estímulos externos ou as experiências que temos; b) atitude: uma postura cultural formada por um conjunto de experiências, a posição que tomamos diante do mundo; c) visão de mundo: é a experiência conceitualizada, é um sistema de crenças (TUAN, 2012, p. 18-19).

A título de ilustração, as percepções, atitudes e valores em relação à praia no sentido mais geral - nem sempre foram as mesmas. Nas vultosas páginas de Sobrados e mucambos, cuja primeira edição data de 1936, Gilberto Freyre discorre sobre o declínio do patriarcado rural no final do século XVIII, mas não deixa de atentar para a vida cotidiana e paras os espaços das cidades. As representações coletivas acerca da praia não foram deixadas de lado por esse intérprete:

As praias, nas proximidades dos muros dos sobrados do Rio de Janeiro, de Salvador, de Recife, até os primeiros anos do século XIX eram lugares por onde não se podia passear, muito menos tomar banho salgado. Lugares onde se faziam despejos; onde se descarregavam os gordos barris transbordantes de excremento, o lixo e a porcaria das casas e das ruas; onde se atiravam bichos e negros mortos. $\mathrm{O}$ banho salgado é costume recente da fidalguia e da burguesia brasileira que, nos tempos coloniais e nos primeiros tempos da Independência, deu preferência ao banho de rio. "Praia" queria dizer então imundície (FREYRE, 2012, p. 313).

\footnotetext{
${ }^{39}$ Não consta a palavra "prosaicista" no Dicionário Houaiss da Língua Portuguesa, tampouco na tradução portuguesa de Artur Mourão, não obstante ter sido utilizada por Sérgio Marques dos Reis, tradutor da versão aqui resenhada. Talvez a palavra que melhor traduziria em língua portuguesa o conceito de Simmel fosse "prosaica", que além de ser algo comum ou trivial (sem poesia), conota aquilo que é "aferrado ao lado prático e material da vida" (HOUAISS, 2001, p. 2314), o que, a meu ver, está mais próximo da ideia do autor.
} 
No Brasil daquele período havia uma atitude de repulsa àquele ambiente, percebido como "lugares onde se faziam despejos" e sendo valorado como "imundície" - isso quando contrastamos com o hábito de se passear pelas areias ou de se banhar nas águas do mar. ${ }^{40}$ Sem perdermos de vista as comunidades pesqueiras, pensemos naqueles que estão mais distantes do mar: os burgueses e fidalgos de Freyre, os viajantes, os banhistas de fins de semana ou os turistas.

De fato, as praias tornaram-se bastante populares após a Segunda Guerra, quando uma horda de pessoas nos Estados Unidos e na Europa passou a frequentálas. De acordo com Tuan (2012, p. 166), essa mudança de atitude ambiental está associada ao crescimento dos balneários, à construção de ferrovias, ao consumo de automóveis e, principalmente, a uma nova avaliação da natureza. "Praia" deixou de significar "imundície" e passou a significar "saúde" e "prazer". ${ }^{41}$ Remodelada em função de um projeto de civilização, a praia tornou-se um dos símbolos da modernidade, de modo que "o gosto pela vida balneária passava a ser parte inalienável de um estilo de vida referente a uma determinada posição no espaço social" (O’DONNELL, 2013, p. 108).

Isso não quer dizer que, para os pescadores de Piratininga, por exemplo, praia seja sinônimo de "lazer", "bronzeamento", "meditação" ou "esportes aquáticos". Para eles, praia é "trabalho", "sustento", “casa”, "família”, "tradição", "memória". Um mesmo espaço abriga, portanto, uma infinidade de significados, não necessariamente compartilhados pelos diferentes atores que o ocupam. Essas visões de mundo podem ser antagônicas: o que é um espaço qualquer para uns; é um lugar para outros, uma topofilia.

\section{2.}

\section{Sentidos e interesses}

O espinhoso debate antropológico acerca do conceito de cultura (KUPER, 2002) tem produzido algumas definições que, embora problemáticas, podem nos

\footnotetext{
${ }^{40}$ Vale lembrar que, do ponto de vista econômico, logístico e belicoso, durante o período colonial a ocupação litorânea foi privilegiada em detrimento da expansão para o sertão, conforme nos lembra outro intérprete, Sérgio Buarque de Holanda (2006, p. 101), contemporâneo de Freyre.

${ }^{41}$ Em 1750, o Dr. Richard Russel publicou um livro a respeito do uso da água do mar no tratamento de doenças glandulares, cuja repercussão parece ter contribuído para que o mar passasse a ser um ambiente atrativo (TUAN, 2012, p. 165).
} 
auxiliar nesta etapa de compreensão. Refiro-me especificamente às noções defendidas por Geertz (2014) e Sahlins (1990), preocupados com uma dimensão simbólica da cultura.

Para Geertz, cultura "consiste em estruturas de significado socialmente estabelecidos" (2014, p. 9). Ela é pública porque o significado supostamente o seria. Todos nós, brasileiros, saberíamos, assim, o que significa o ato de se fantasiar durante o Carnaval, mesmo que ignorássemos os significados das fantasias mexicanas utilizadas em ritos funerários. Poderíamos interpretar o uso das vestimentas carnavalescas de diferentes maneiras, mas saberíamos quando são “apropriadas” ou “inapropriadas”, “bonitas”, “escandalosas” ou "indecentes”. Nós compartilharíamos esses significados por conta de nossa ligação cultural.

De maneira semelhante, Sahlins entende a cultura como uma estrutura, isto é, como "relações simbólicas de ordem cultural" (1990, p. 8). A estrutura é composta por inúmeros significados (ou sentidos) que se relacionam entre si e que possuem uma historicidade. Esses significados não estão engessados no tempo e no espaço, são postos em risco constantemente pelos agentes ou pelas próprias ações: “(...) se 'os amigos criam presentes', os presentes também criam amigos', ou talvez como melhor diriam os esquimós, 'dádivas criam escravos - como os chicotes criam cachorros"” (SAHLINS, 1990, p. 12).

Mas além de estarem abertos à negociação, os significados também estão sujeitos à contingência de eventos que ocorrem na vida social. Um acontecimento transforma-se em um evento ao ser interpretado pelo grupo. Nesse momento, é apropriado e absorvido pelo esquema cultural, adquirindo uma significância histórica (Idem, p. 15). Os eventos podem reafirmar ou modificar as relações simbólicas.

A ideia de Geertz segundo a qual a cultura enquanto um sistema simbólico poderia ser estudada autonomamente, sem levar em consideração as condições sociais (ERIKSEN; NIELSEN, 2010, p. 125), parece-me equivocada, sobretudo por atribuir tamanha eficácia aos símbolos (WOLF, 2003, p. 336). Do mesmo modo, não me parece convincente que diferentes grupos pertencentes a uma mesma sociedade compartilhem necessariamente das mesmas compreensões culturais (Ibidem), como sugerem Geertz e Sahlins. As polaridades metafóricas invocadas pelos grupos estudados são compreendidas de maneira diferente em uma mesma 
sociedade, a exemplo do que se observou sobre a casa e a rua (MELLO et al, 1981; DAMATTA, 1997).

\begin{abstract}
Essas metáforas são intrinsecamente polissêmicas, tão abundantes em possíveis significantes que podem abarcar qualquer situação. Para fazê-las funcionar em cenários particulares, é necessário que seu âmbito seja restrito a um conjunto pequeno de referentes. O que Lévi-Strauss chamou de "o excedente de significantes" deve ser submetido a uma seleção parcimoniosa antes que a lógica da integração cultural possa ser atualizada. Essa indexação, como alguns a chamaram, não é um processo automático, mas passa pelo poder e por conflitos de poder, com todos os tipos de consequência para a significação (WOLF, 2003, p. 337, grifo meu).
\end{abstract}

Diferentemente de Geertz e Sahlins, proponho que pensemos não em esquemas culturais de sociedades longínquas (como o Marrocos ou o Havaí), porém em visões de mundo de diferentes grupos que vivem dentro de uma mesma sociedade, falam a mesma língua e compartilham um número limitado de significados. Por ora, não é preciso imaginarmos punks e membros de torcida organizada; pensemos nos significados atribuídos a um molusco bivalve (o mexilhão) por dois grupos de pescadores de duas praias de Niterói (RJ).

Em Piratininga, do ponto de vista da espécie mais ou menos cobiçada economicamente, o mexilhão é hierarquicamente inferior a peixes como a tainha, a corvina ou o linguado. O foco das estratégias de captura não está voltado prioritariamente para ele. No entanto, isso não significa que não seja catado ou não haja pessoas que tenham por ele alguma predileção em termos alimentícios. Diferentemente, na Praia Grande, a despeito da coexistência de diferentes estratégias de pesca, o mexilhão é a principal fonte de renda do grupo local; lá, o mexilhão "é ouro preto" (STEVENSON, 2014; TARDELLI; STEVENSON, 2016, p. 13).

Todavia, a partir da memória vivida dos marisqueiros da Praia Grande, constatamos um contraste entre o passado e o presente, uma vez que o mexilhão passou a ser mais valorizado na atualidade. Ainda que nas décadas anteriores houvesse catadores de mexilhão, a pesca era a principal atividade praticada naquela praia. Com o surgimento de uma série de empreendimentos político-econômicos, saem do seu lugar e passam a ocupar outros espaços, exercendo outras práticas (TARDELLI; STEVENSON, 2016, p. 13). Esses acontecimentos tornaram-se eventos e transformaram a estrutura de significados local (SAHLINS, 1990, p. 191). 
Seguindo a mesma linha de raciocínio, penso que o último incêndio que acometeu o barracão de pesca na Praia de Piratininga foi interpretado e incorporado na estrutura dos pescadores. Enquanto evento, o incêndio trouxe mudanças estruturais que se refletem tanto nas representações do grupo a respeito daquela construção ("isso aqui parece uma favela") quanto nas concertações entre os interessados em ocupar um espaço na praia (após o incêndio, o barracão adquiriu uma nova feição, além de terem surgido novas construções).

Igualmente, os pescadores enunciam uma série de eventos que trouxeram mudanças substanciais para suas vidas: o loteamento de Piratininga, a abertura do Canal de Camboatá pela empresa Veplan Imobiliária, a pavimentação da Rodovia Amaral Peixoto (RJ-106), a construção da Resex, a especulação imobiliária, o surgimento do nylon plástico, o avanço tecnológico, a globalização. Distantes da falsa ideia de uma vida insular em um suposto estado de pureza, os pescadores vivenciam inúmeros processos, cujos interesses dos participantes nem sempre são convergentes.

Assim, ao pensarmos em determinadas situações sociais, devemos levar em consideração que os signos são compostos não somente por sentidos, mas por interesses, isto é, por aspirações humanas - entendidas amplamente -, que pressupõem reflexão e cálculo, não estando restritas aos aspectos materiais do bemestar de um indivíduo ou à dimensão econômica (HIRSCHMAN, 2002, p. 54). Dentro dessa perspectiva, "as pessoas decidem seu modo de agir baseadas no que é melhor para elas e não, como os funcionalistas estruturais nos fariam crer, somente baseadas nas normas de comportamento aceitas e sancionadas (BOISSEVAIN, 2010, p. 211).

Cada forma espacial produzida manifesta projetos, necessidades, utopias e interesses (MORAES, 2005, p. 22). Em diferentes sociedades, por exemplo, o retângulo foi adotado como a forma ideal das cidades porque representava o cosmo (TUAN, 2012, p. 222). Havia nelas o interesse de se aproximar de suas divindades. A construção de Brasília, cujo plano pode ser comparado a um pássaro ou avião, pode ser interpretada como uma tentativa de se "romper o domínio do mar na civilização brasileira, para dar status à agricultura e à população rural” (Idem, p. 236) ou como um distanciamento entre representantes e representados politicamente. 
Em um sistema cultural, o signo tem um valor conceitual fixo em contraste com outros signos; na ação, o signo aparece como interesse, que é seu valor instrumental para o sujeito ativo (SAHLINS, 1990, p. 187). Tornemos as coisas mais claras: o "barracão", enquanto signo, possui um sentido conceitual de acordo com a sua posição diferencial no esquema total de objetos simbólicos, composto, dentre outros elementos, por casa, praia, campo, tainha, mexilhão, canoa ou barco de alumínio.

Figura 37 - Esquema de objetos simbólicos dos pescadores de Piratininga.

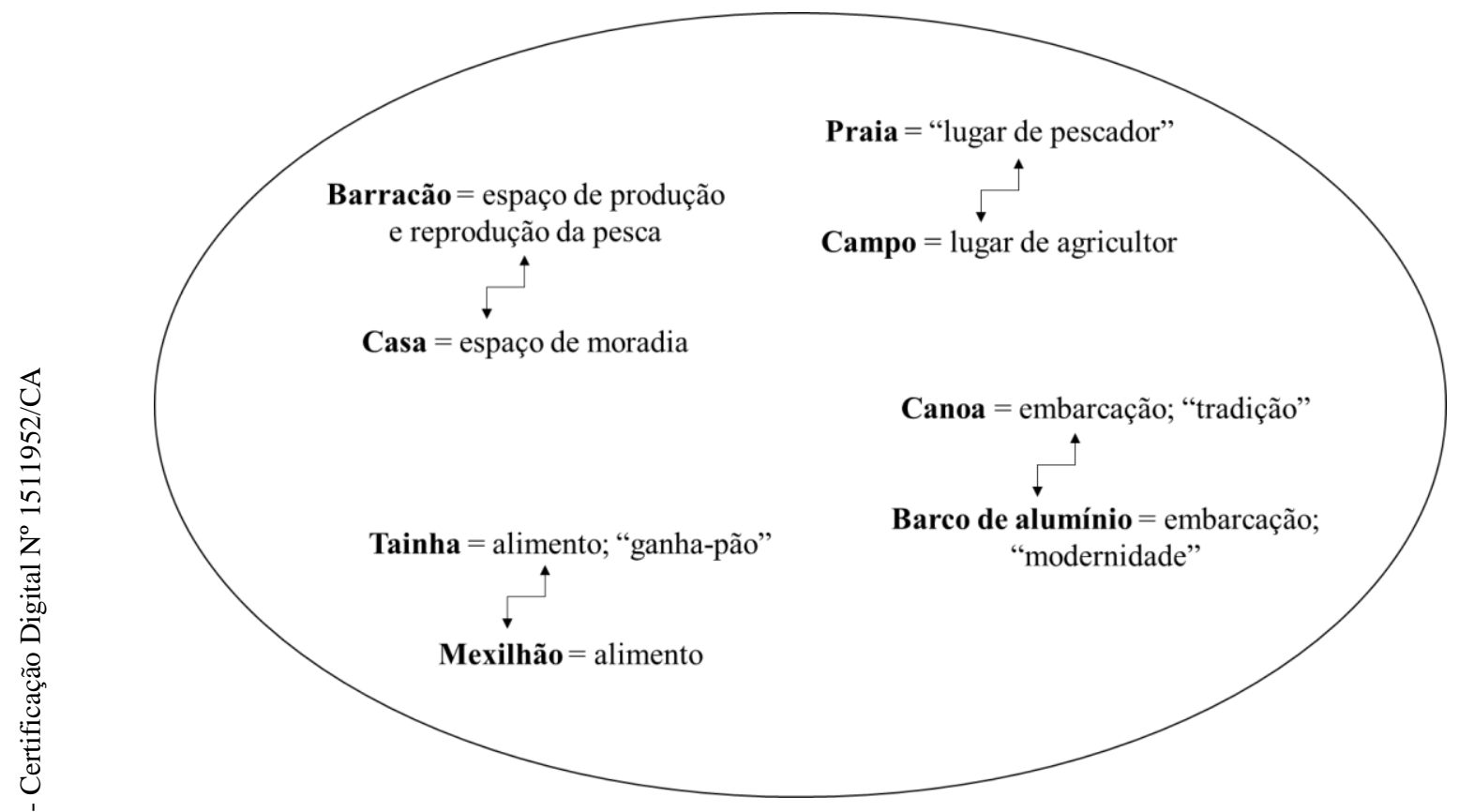

Fonte: Elaborada pelo autor.

O problema é que cada objeto simbólico representa um interesse diferencial para diversos atores, “de acordo com a sua posição em seus esquemas de vida”, já que "meu interesse em algo não é igual ao seu sentido (SAHLINS, 1990, p. 187). Assim, o barracão pode significar "acampamento" e "associação", para o pescador de arrasto de praia; "favela" e "confusão", para pescadores de rede de espera; "bar/restaurante", para barraqueiros e turistas; "rancho", para antropólogos; ou, até mesmo, "cenário de novela", para cenógrafos. 
Figura 38 - Objeto simbólico representando sentidos distintos para atores diferentes

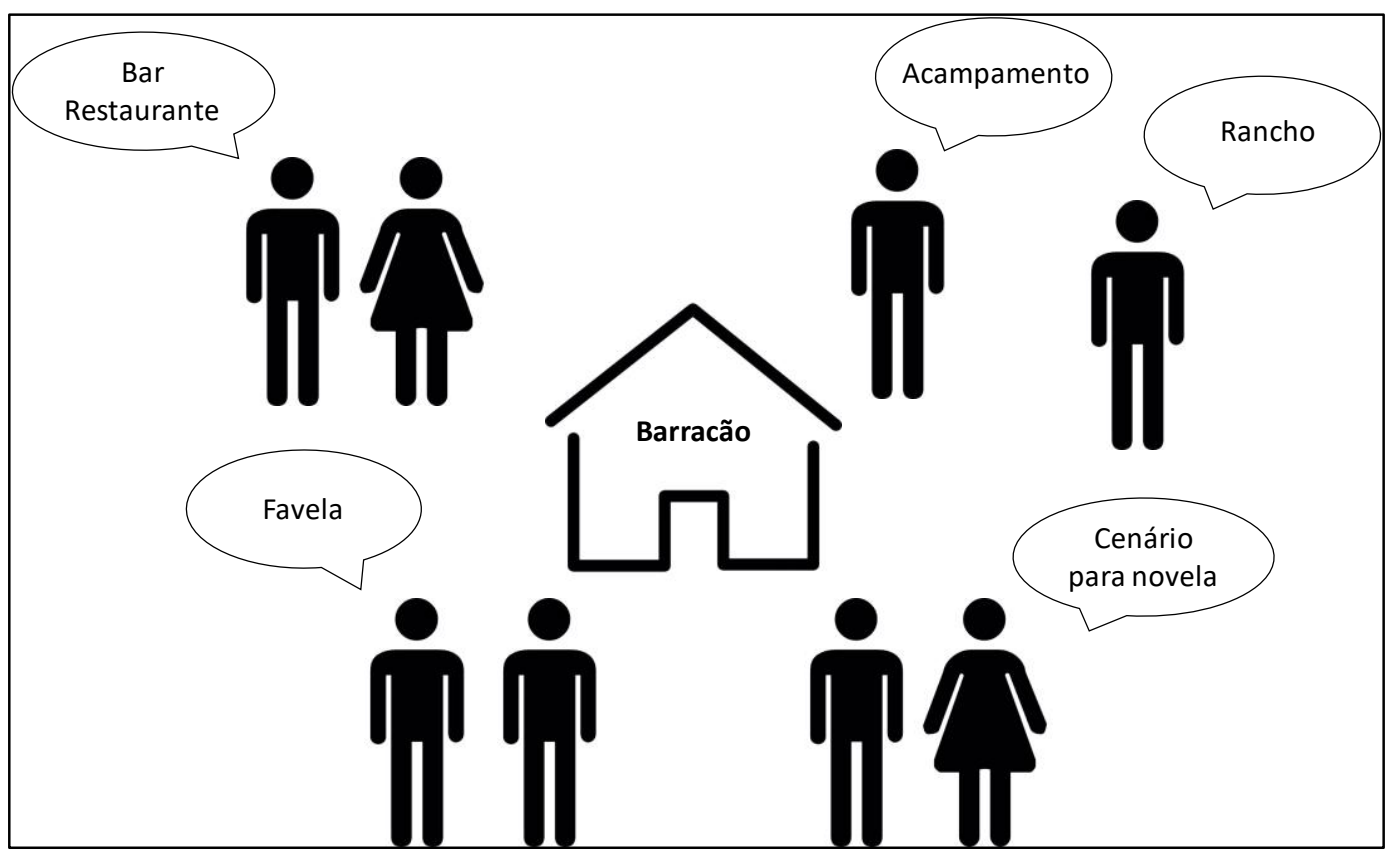

Fonte: Elaborada pelo autor.

Os signos, em ação, são projetados de forma diferencial, a depender dos interesses de cada ator, das relações sociais estabelecidas e dos contextos empíricos onde estão inseridos. O signo corre, pois, um duplo perigo, tanto subjetivo quanto objetivo:

\footnotetext{
Subjetivamente pelo uso motivado dos signos pelas pessoas para seus projetos próprios, objetivamente, por ser o significado posto em perigo em um cosmos totalmente capaz de contradizer os sistemas simbólicos que presumivelmente o descreveriam (SAHLINS, 1990, p. 186).
}

Objetivamente, passa a haver uma dissonância entre as palavras e as coisas. Pensemos na visita do capitão Cook ao Havaí (SAHLINS, 1990, p. 178). Nas décadas seguintes à sua chegada, muitos conceitos tradicionais foram reavaliados. $\mathrm{O}$ tabu, que se referia às coisas colocadas à parte para o deus, passou a se referir à interdição de relações comerciais com navios estrangeiros, conforme prescrevia o grande Kamehameha. Fascinada pelos produtos luxuosos trazidos pelos europeus, a chefia não queria ver sua demanda por consumo reprimida pelo crescente interesse da população em consumir as mesmas quinquilharias.

Dessa forma, os diferentes atores que encontramos na Praia de Piratininga “estão envolvidos numa luta propriamente simbólica para imporem a definição do 
mundo social mais conforme aos seus interesses" (BOURDIEU, 2015, p. 8). Os símbolos que permeiam a vida cotidiana não adquirem significados da noite para o dia: “(...) não é um processo automático, mas passa pelo poder e por conflitos de poder, com todos os tipos de consequência para a significação" (WOLF, 2003, p. $337)$.

\section{3.}

\section{Do poder de definir}

A análise simbólica não deve ser reduzida, portanto, a virtualidades e abstrações. A definição e a utilização de significados implicam em relações de poder que envolvem pessoas feitas de carne e osso. Entendo por relações de poder relações marcadas pela desigualdade entre os que mandam e os que obedecem, "que realiza uma capacidade absoluta de divisão na sociedade" (CLASTRES, p. 2015, 151). Nesse sentido, poder e força confundem-se (SENNETT, 2001, p. 31).

Por outro lado, a fim de dar conta da complexidade do problema, vejamos a conceituação proposta por Eric Wolf, para quem é possível pensar em quatro modos diferentes de poder: 1) o poder como atributo da pessoa, como potência ou capacidade; 2) o poder que encontramos nas relações interpessoais, nas quais uma pessoa tentar impor sua vontade à outra; 3) o poder tático ou organizacional, que controla os cenários em que as pessoas podem mostrar suas potencialidades e interagir com as outras; 4) o poder estrutural, "que não funciona somente dentro dos cenários ou domínios, mas também organiza e orquestra os próprios cenários e especifica a distribuição e direção dos fluxos de energia" (WOLF, 2003, p. 326).

O quarto tipo de poder possibilita que o campo social de ação seja moldado, de modo a tornar possível alguns tipos de comportamento, enquanto dificulta ou impossibilita outros. Além disso, a noção de poder estrutural explicita uma deficiência do conceito de estrutura cultural proposto por Sahlins, na medida em que interpretamos como os havaianos entenderam as mudanças provocadas pela visita de Cook, mas não explicamos "como formas dadas de significação relacionam-se com transformações de agricultura, povoamento, organização sociopolítica e relações de guerra e paz" (WOLF, 2003, p. 340). É preciso, pois, compreender as consequências do exercício de poder. 
A partir dessa óptica, ao analisarmos a significância histórica do conceito de população tradicional, por exemplo, notamos que "o papel do poder se torna mais evidente em ocasiões em que as grandes transformações organizacionais põem a significação em cheque" (Idem, p. 339). Além disso, percebemos que o poder de definir - ou inventar - conceitos é exercido de inúmeras maneiras por muitos atores e instituições. Vejamos o caso dos seringueiros do Acre.

No decorrer da longa trajetória de construção das Reservas Extrativistas, cujo objetivo inicialmente dizia respeito à busca, pelos seringueiros, da afirmação do seu modo de vida (LOBÃO, 2010, p. 26), havia três públicos com interesses nem sempre convergentes. O primeiro público era formado pelos próprios seringueiros, que se reconheciam como extrativistas. $\mathrm{O}$ segundo era formado por representantes da sociedade nacional, como alguns cientistas sociais, que interagiram com os seringueiros no intuito de "traduzir" os discursos oficiais - leis, organizações, conceitos abstratos - para os extrativistas e de dar visibilidade nacional e internacional aos enunciados destes. Um terceiro público, que estava inserido no segundo, era constituído por algumas ONGs que desempenhavam o papel de "inculcar valores aos grupos em disputa e potencializar seus papéis em disputas particulares e situadas em localidades distintas daqueles cenário do conflito pela terra" (Idem, p. 44).

\begin{abstract}
Ao focar no primeiro público, vemos que ele era formado por seringueiros, em um primeiro momento. Passaram a extrativistas, quando ainda dominavam a interpretação e nominação do processo. Finalmente foram oficializados no mundo das regras, leis e regulamentos como "população tradicional" (LOBÃO, 2010, p. 44).
\end{abstract}

Em sua reconstrução da sociogênese do conceito de população tradicional, Lobão sustenta que, no Brasil, essa invenção está diretamente vinculada à história dos povos amazônicos (LOBÃO, 2010, p. 46). Se até a década de 1980 estes eram classificados como índios, caboclos ou ribeirinhos e colonos, no final da década de 1990 alguns autores passaram a defender a aplicação do termo em "uma vertente extensional, ou seja, mediante a enumeração daqueles que poderiam ser enquadrados na categoria ou os potenciais candidatos ao enquadramento".

Quando acionado em contextos de demanda territorial, o conceito de população tradicional adquire feições diferenciais: 1) em um contexto ambientalista, atende à necessidade do preservacionismo em atacar os grupos 
sociais presentes em unidades de conservação integral - aqui, "tradicional" significa "atraso"; 2) em outro contexto ambientalista, aproximou socioambientalistas e os grupos que historicamente exploram de maneira sustentável os recursos naturais - aqui, "tradicional" significa "sustentável”; 3) no contexto de debate da Convenção 169 da Organização Internacional do Trabalho (OIT) sobre autonomia territorial, o conceito determinou direitos para determinados grupos das sociedades nacionais, como indígenas e quilombolas - aqui, "tradicional” é "direito", "reconhecimento" (LOBÃO, 2010, p. 46).

O conceito de população tradicional chegou às praias de Itaipu e Piratininga, dentre outras vias, através de atores e instituições envolvidas no processo de construção da Reserva Extrativista Marinha (Resex-Mar Itaipu), a exemplo das associações de pescadores, colônias, do Instituto Brasileiro do Meio Ambiente e dos Recursos Naturais Renováveis (IBAMA), do Instituto Chico Mendes de Conservação da Biodiversidade (ICMBio), do Instituto Estadual do Ambiente (INEA), do Nupij, da Biologia Marinha da Universidade Federal Fluminense (Biomar) e do Centro Nacional de Desenvolvimento Sustentado das Populações Tradicionais $^{42}$. Entre reuniões, debates, relatórios técnicos, legislações nacionais e internacionais, o conceito era invocado a todo instante (MIBIELLI, 2014).

O signo da tradicionalidade modifica-se contextualmente em conformidade com o sentidos e os interesse em disputa. Como vimos, Cléber, o mestre das canoas, aciona o conceito de tradicional para legitimar a existência do barracão e a maneira pela qual ele acredita que o espaço deva ser partilhado. Sustenta que as pescas que se utilizam das canoas são "mais tradicionais" do que aquelas que se valem das facilidades do "plástico" e da "tecnologia", que dispensa o domínio de determinados saberes, como a confecção e reparo de redes.

Cléber: Eles [os demais pescadores] têm que proteger as canoas, já que elas é que têm o direito ao espaço, não me condenar. É por causa das canoas que nós temos direitos a esse espaço. Porque [no passado] não havia outras pescarias, só tinha

\footnotetext{
${ }^{42}$ Esta sigla foi utilizada de 1992 a 1995, sendo modificada inúmeras vezes: 1995-2004: Centro Nacional para o Desenvolvimento Sustentado das Populações Tradicionais; 2004: Centro Nacional de Populações Tradicionais e Desenvolvimento Sustentável; 2009: Centro Nacional de Pesquisa e Conservação da Sóciobiodiversidade Associada a Povos e Comunidades Tradicionais (MIBIELLI, 2014).
} 
canoa; não tinha caíco com rede. Não existia plástico; o plástico veio há pouco tempo, quando saiu rede plástico para você comprar ali na loja.

Ao contrário, na concepção de Josi, o que dá legitimidade para que possam ocupar o espaço é o fato de estarem devidamente registrados como "pescadores profissionais" no órgão competente: "Pescador que é pescador tem que ter carteira. Se tiver carteira tem direito ao espaço", afirma. Mas, assim como o conceito de tradicional, o conceito de pescador profissional é um enquadramento realizado por diferentes atores, instituições e órgãos governamentais (MIBIELLI, 2014). Em comum, os dois conceitos possuem uma historicidade e estão imbricados em relações estruturais de poder.

\section{4 .}

\section{Da autoridade do autor}

$\mathrm{O}$ ato de atribuir significados às coisas é um ato autoral. E o autor é, antes de tudo, alguém que exerce uma autoridade (vide a raiz da palavra); sua conotação implica algo de produtivo (SENNETT, 2001, p. 31). Costumamos perder de vista "que toda língua é uma classificação e que toda classificação é opressiva" (BARTHES apud SINDER, 1997, p. 307). Em Piratininga, cada tentativa de classificar o barracão pode ser entendida como um exercício de autoridade relacionado com os respectivos interesses na ocupação daqueles espaço.

Desse modo, há uma relação umbilical entre o exercício do poder e as manifestações da autoridade, uma vez que esta consiste em "uma tentativa de interpretar as condições de poder, de dar sentido às condições de controle e influência, definindo uma imagem de força" (SENNETT, 2001, p. 33). Nesse sentido, o poder pode estar simbolizado tanto nos monumentos erguidos à autoridade, como igrejas, santuários e prédios governamentais (Idem, p. 32), quanto nas diferentes morfologias e significados que um barracão de pesca pode vir a assumir.

Ao compreendermos as disputas em torno do barracão como uma disputa autoral, isto é, uma disputa pela autoridade, passamos a visualizar os diferentes sentidos atribuídos a um mesmo espaço, os distintos interesses e as variadas formas de edificação prescritas. Além disso, como em um texto literário, científico ou 
antropológico, entendemos como o real é disciplinado e submetido a um discurso narrativo fechado e totalizante (SINDER, 1997, p. 316).

Para Cléber, o barracão é um "acampamento", porque os pescadores devem se adaptar à natureza, precisam “evoluir", não ficar parados no tempo. A pesca é "tradicional" porque se utiliza de elementos do meio ambiente (o tronco para fazer a canoa; o murici que tinge as redes) e domina os movimentos desse mesmo meio (luas, marés etc.). O interesse reside na "resistência", na preservação de um "núcleo de pesca artesanal", em respeito à memória dos mais velhos. Quem se opõe a essa concepção é classificado como "olho grande", pois não pensa na coletividade, age individualmente, visando apenas a obtenção de bens materiais. Contraditoriamente, ele defende a necessidade de sua mulher possuir uma “cantina”, seja para resguardar suas canoas do avanço dos barraqueiros pelas extensões da praia, seja como forma de se auferir uma renda complementar, que contribua para a manutenção da "tradição". Nesse caso, o material improvisado do "acampamento" vai dando lugar à alvenaria, à fixação no espaço: pisos cimentados e paredes com tijolos.

O problema é que a autoridade que ele possui enquanto mestre não se confunde com a disputa pelo poder em face do barracão. Eis um dos paradoxos constatados. Dentro ou fora da canoa, o mestre não está investido de poder, não lhe foi conferida a capacidade de mandar e desmandar nos demais membros da companha, uma vez que o princípio hierárquico inscrito nos lugares da embarcação diz respeito à relação do todo com as partes que compõem o todo, não a relações verticais de mando e obediência (DUMONT, 1993, p. 129). O prestígio que o mestre possui enquanto porta-voz do grupo, por suas qualidades e pelo seu reconhecimento (os saberes que domina, o aval dos mais velhos etc.), não representa uma concentração de poder (CLASTRES, 2015, p. 140). O mestre encontra-se impotente diante da inobservância das "regras".

Cléber: (...) Fui eu que ensinei Nareba a pescar, fui eu que ensinei todos esses malucos a pescar e hoje eu não posso com o tipo de pesca que eu faço, porque eles não deixam, colocam a rede ali. Eu tenho um limite, eu tenho regras a cumprir naquela pescaria.

O outro pescador envolvido no conflito, Josi, concebe o barracão como um “coração de mãe", pois está aberto a todo mundo, ainda que tenha colocado um 
portão com cadeado e que tenha se apropriado de maneira particularizada de uma área que correspondia a mais de oito pescadores. Ele apenas coloca "ordem" e mantém tudo "limpo". Acredita que sua ocupação está legitimada pela posse da carteira de pesca, independentemente de ter trazido para o espaço o "pessoal do Cafubá", que, além de não ser constituído por pescadores, "ninguém conhecia". Josi, como Cléber, também “faz comércio" no barracão, embora tenha criticado este em algumas ocasiões. Mas ambos parecem concordar nesse aspecto, já que relacionam a venda de comidas e bebidas à "sobrevivência na beira na praia":

Cléber: Em toda praia, em todo Nordeste, até mesmo em Copacabana, em todo canto o pescador dá o seu jeito; sobrevive na beira da praia, vende seu peixe. Você vive ali, você é dali, por que você não pode aproveitar a temporada? Os outros podem, todo mundo pode... Se é isso que dá a tradição do local.

Os barraqueiros, por sua vez, também veem aquele espaço como uma oportunidade econômica. Se os pescadores podem utilizar o espaço para fins comerciais, eles também o podem. Não são "pescadores", mas são "conhecidos", “parentes", "vizinhos" e "amigos". Entretanto, não permanecem na praia durante todo o ano, apenas quando há um interesse do ponto de vista pecuniário. Sua apropriação é particularizada, voltada para uma única finalidade (o comércio) e está sujeita a negociações de viés mercantil, embora, em alguma medida, também estejam inseridos em laços de reciprocidade que norteiam as relações sociais dos pescadores locais.

Eis o desenrolar de um drama: quando o espaço passa a ser negociado, adquirindo traços de propriedade, perde seu sentido enquanto lugar. Assim, se a reconfiguração do espaço era marcada pela retomada do foco de pesca e pelas atividades ligadas direta ou indiretamente a ele, passa a ter como norte outras atividades, não necessariamente ligadas a uma topofilia.

Em suma, sob a perspectiva aqui adotada, podemos compreender que o que está em jogo no conflito na Praia de Piratininga é a natureza do espaço, ou seja, os inúmeros significados que são atribuídos ao barracão de pesca por diferentes atores, assim como as diferentes formas de legitimação da ocupação enunciadas nos discursos. Trata-se de uma disputa política de poder, na medida em que a capacidade de definir significados põe em xeque tanto o significado dos objetos 
quanto os próprios objetos e sua posição estrutural: os sujeitos "deixam de ser escravos de seus conceitos para se tornarem seus senhores" (SAHLINS, 1990, p. 11). 
TERCEIRA PARTE:

RECONSTRUIR 


\section{6.}

\section{"Aqui só tem conflito!"}

Chegamos, enfim, à última parte deste trabalho. Aqui, farei a minha interpretação do vivido em conceitos abrangentes, projetando algumas propostas (LOBÃO, 2010, p. 13-14). O título deste capítulo é uma referência a uma das afirmações que ouvi na praia: “Aqui só tem conflito!”. Nesse sentido, tentarei definir o conflito na Praia de Piratininga, a partir de algumas discussões sociológicas (DURKHEIM, 2013; SIMMEL, 1983) e de algumas interpretações acerca da maneira pela qual a sociedade brasileira lida com o conflito (DAMATTA, 1997; LOBÃO, 2000; KANT DE LIMA, 2010). Além disso, farei uma distinção entre dramas sociais (TURNER, 2008) e conflitos intratáveis (LOBÃO, 2014, p. 45). Por fim, tentarei analisar os significados da categoria olho grande, recorrentemente invocada pelos pescadores.

\section{1.}

\section{A natureza sociológica do conflito}

A frase que intitula este capítulo - "aqui só tem conflito" - foi ouvida por mim em diferentes momentos do trabalho de campo. Aparecia nos discursos dos pescadores principalmente em situações de tensão, nas quais eram deflagradas disputas em função dos espaços da praia. Mais do que uma categoria analítica, portanto, a palavra “conflito" está eivada de significados contextualmente situados.

Por um lado, com uma lente durkheimiana, poderíamos interpretar o conflito como uma ausência de normas (as regras foram "massacradas"). Por outro, o uso do advérbio de exclusão "só” poderia revelar a permanência, o caráter cíclico e o peso do conflito na vida social daqueles pescadores (quando chega o verão, é sempre a mesma coisa). Nesse último caso, o conflito identificar-se-ia com o conceito de sociação cunhado por Simmel, isto é, aquilo que visa reproduzir ou manter a vida em sociedade (SIMMEL, 1983).

Durkheim distingue a solidariedade mecânica, própria das sociedades ditas "inferiores", da solidariedade orgânica, presente nas sociedades "superiores" e mantida, dentre outros mecanismos, pela divisão do trabalho. A primeira apenas é 
viável "na medida em que a personalidade individual é absorvida na personalidade coletiva; a segunda só é possível se cada um tiver uma esfera de ação própria, por conseguinte, uma personalidade" (DURKHEIM, 2013, p. 108). Nota-se, pois, que as sociedades onde os indivíduos distinguem-se uns dos outros têm uma unidade maior, proporcional ao aumento da individuação das partes. Em outras palavras, segundo Durkheim, "a individualidade do todo aumenta ao mesmo tempo que a das partes; a sociedade torna-se mais capaz de se mover em conjunto, ao mesmo tempo em que cada um de seus elementos tem mais movimentos próprios".

Para Durkheim, o indivíduo não poderia suportar solitariamente a existência: é o social que forja a liga que une os indivíduos. Se não houvesse essa proteção, viveríamos em total anomia. Por isso, o suicídio, uma anomia social, ocorre com mais frequência em períodos de crise, durante os quais as expectativas - econômicas, políticas etc. - são abaladas. Do mesmo modo, a divisão do trabalho anômica se dá quando falha a ideia de sinergia e integração, geralmente durante crises industriais ou comerciais e antagonismos entre o trabalho e o capital (DURKHEIM, 2013, p. 368-369).

À medida que as sociedades desenvolvem-se e complexificam-se, a divisão do trabalho passa a produzir outra forma de solidariedade, qual seja, a orgânica. É uma solidariedade de interdependência; cada um exerce uma função e todos colaboram. Conforme Durkheim (2013, p. 268), “a divisão do trabalho é, pois, um resultado da luta pela vida, mas é um seu desenlace atenuado. De fato, graças a ela, os rivais não são obrigados a se eliminarem mutuamente, mas podem coexistir uns ao lado dos outros". Nesse sentido, a divisão do trabalho não apenas evita conflitos e promove a coesão social, como também contribuiu para o aumento da felicidade:

A maior intensidade da luta implica novos e penosos esforços, que não são de natureza a tornar os homens mais felizes. Tudo acontece mecanicamente. Uma ruptura de equilíbrio na massa social suscita conflitos que só podem ser resolvidos por uma divisão do trabalho mais desenvolvida: este é o motor do progresso (DURKHEIM, 2013, p. 268).

Diferentemente, na teoria social elaborada por Simmel a desarmonia e a competição desempenham um papel tão importante quanto a harmonia e a associação na configuração das sociedades (SIMMEL, 1983, p. 124). O conflito (Kampf), fomentado pelo ódio, pela inveja, pela necessidade e pelo desejo, não é simplesmente representado como um fator atípico ou "anormal": trata-se, isto sim, 
de uma forma de sociação. A noção de sociação engloba todas as formas de interação entre os homens e conduz à busca de uma unidade, mesmo que para isso seja necessário eliminar uma das partes conflitantes (Idem, p. 122). A vida em sociedade seria o resultado de um equilíbrio entre tendências favoráveis e desfavoráveis.

Assim, as discordâncias, segundo Simmel, não devem ser vistas sob uma perspectiva puramente negativa, como meras deficiências sociológicas. Ao contrário, o antagonismo possui um papel positivo e integrador na sociedade.

O desaparecimento de energias de repulsão (e, isoladamente consideradas, de destruição) não resulta sempre, em absoluto, numa vida social mais rica e mais plena (assim como o desaparecimento de responsabilidades não resulta em maior propriedade), mas num fenômeno tão diferente e irrealizável quanto se um grupo fosse privado das forças de cooperação, afeição, ajuda mútua e convergência de interesses (SIMMEL, 1983, 126-127).

Atento as interações que ocorrem no espaço urbano, Simmel acredita que as “energias de repulsão" estão presentes não apenas na competição em geral, mas entre os componentes de um mesmo grupo: “A oposição de um membro do grupo a um companheiro, por exemplo, não é um fator social puramente e negativo, quando muitas vezes tal oposição pode tornar a vida ao menos possível com as pessoas realmente insuportáveis" (SIMMEL, 1983, 126-127).

Não obstante, o sociólogo alemão defende que as "relações de conflitos" não são capazes de produzir, sozinhas, uma estrutura social. É preciso que estejam em cooperação com "forças unificadoras", tendo em vista que "só as duas juntas constituem o grupo como uma unidade viva e concreta" (Idem, p. 128).

Um forte aliado do conflito na construção das estruturas sociais é a competição. Sob o liberalismo, a competição enseja a luta de todos contra todos, a maximização dos interesses individuais e, ao mesmo tempo, a luta de todos para o bem de todos, pois os laços sociais impedem a aniquilação do Outro (LOBÃO, 2010, p. 145). 


\section{2.}

\section{O dilema do espaço público brasileiro}

Em seus respectivos trabalhos, Roberto DaMatta e Roberto Kant de Lima (apud LOBÃO, 2010, p. 147) têm sustentado que o conflito não é algo desejável e bem quisto na sociedade brasileira. Haveria uma recusa à explicitação do conflito, na medida em que este é percebido como uma ruptura da ordem. Sendo uma ameaça à sociedade, caberia ao Estado absorver o conflito e extingui-lo. Ambos os autores têm analisado o Brasil a partir de dois modelos relacionais - entendidos enquanto tipos ideais - que orientam as relações entre os segmentos que compõem a sociedade: o hierárquico e o individualista.

No primeiro caso, "o acento incide sobre a sociedade em seu conjunto". Trata-se de ordem e hierarquia, ${ }^{43}$ uma vez que "cada homem particular deve contribuir em seu lugar para a ordem global, e a justiça consiste em proporcionar as funções sociais com relação ao conjunto" (DUMONT, 2008, p. 57). A sociedade é composta por segmentos que formam coletividades. Estes agrupamentos seguem um princípio hierárquico, que coloca um segmento em relação ao todo e não entre si, mantendo a coesão do sistema. Como cada um desempenha uma função, a eliminação de um segmento pode causar desequilíbrio no conjunto. A cada relação hierárquica corresponde um princípio hierárquico, que pode ser prestígio, pureza, status, informação ou riqueza. Assim, “o que ocorre em muitos conflitos não é uma ruptura de uma estrutura estratificada, mas um choque entre princípios hierárquicos distintos" (LOBÃO, 2010, p. 147).

Já no modelo relacional individualista, o indivíduo encontra-se no centro, como se encarnasse a "humanidade inteira: "Ele é a medida de todas as coisas (num sentido pleno todo novo) [...] Ontologicamente a sociedade não existe mais, ela é apenas um dado irredutível ao qual se pede em nada contrariar as exigências de liberdade e igualdade" (DUMONT, 2008, p. 57). Nesse modelo, organizado pelo princípio igualitário, o indivíduo não está contido em um princípio englobante e a eventual supressão de um elemento não ameaça a integridade e o equilíbrio do sistema. O conflito é inerente a esse modelo. Há uma constante disputa pelas

\footnotetext{
${ }^{43}$ Friso, novamente, que hierarquia no sentido aqui empregado diz respeito aos papeis que os membros de uma sociedades são impelidos a desempenhar.
} 
posições sociais, que se encontram acessíveis a todos. A ordem deve ser negociada pelos participantes a cada momento e o conflito pode ser produtor da ordem.

Sob a influência dessa tipificação, DaMatta tem frisado (1997; 1997a; 2010), que a construção da "esfera pública" no Brasil vincula-se à intricada relação entre a casa e a rua. A primeira seria marcada pelas relações pessoais e afetivas e é onde vigoraria a ordem hierárquica, pela qual cada membro da família tem consciência de seu papel e do lugar que ocupa na relação com o todo. Na rua, diferentemente, ter-se-ia a ordem igualitária, o espaço por excelência dos cidadãos e onde circulariam indivíduos, não pessoas. O "dilema brasileiro" consistiria justamente no fato de que características individualistas e hierárquicas convivem simultânea e alternadamente no espaço público brasileiro.

Do mesmo modo, Kant de Lima elaborou dois modelos - ideais e normativos - denominados de paralelepípedo e pirâmide (KANT DE LIMA, 2010, p. 42). No paralelepípedo, onde o topo é igual à base, a sociedade seria constituída por indivíduos com diferentes interesses, porém iguais em direitos, o que os colocaria, permanentemente, em oposição e conflito. Em relação à pirâmide, onde a base é maior que o topo, a sociedade é composta de segmentos desiguais e complementares que devem se ajustar harmonicamente.

Nossa sociedade possui, sob esse prima, um modelo dual, utilizado alternada e alternativamente, no qual o paralelepípedo responde por sua vertente igualitária e a pirâmide, por sua vertente estratificada. No primeiro caso, como a base é igual ao topo e todos são substancialmente iguais, qualquer um pode chegar ao topo. No segundo, entretanto, os caminhos em direção ao topo vão estreitando-se gradativamente. "Aqui a igualdade é formal, e as pessoas são estruturalmente diferentes" (LOBÃO, 2010, p. 147-148). Dessa forma, podemos ver a sociedade brasileira representada por uma pirâmide engastalhada em um paralelepípedo, em um sistema que ora iguala, ora estratifica: 
Figura 39 - Pirâmide engastalhada em um paralelepípedo.

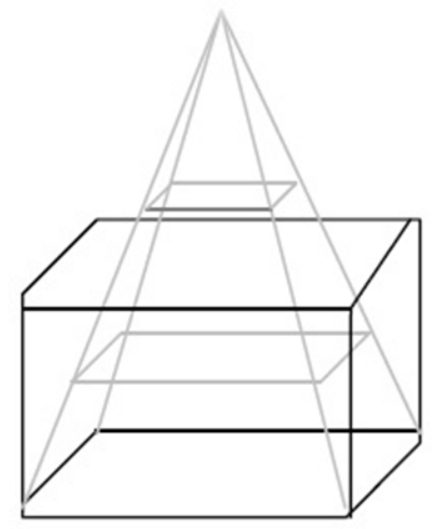

OU

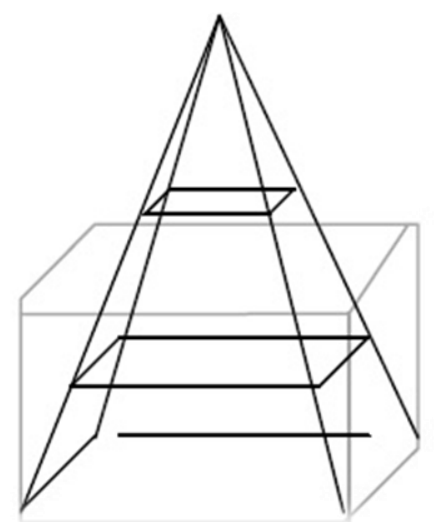

Fonte: LOBÃO, 2000, p. 96.

Uma das peculiaridades da cidadania no Brasil seria, portanto, a combinação, no espaço público, de lógicas igualitárias (uma sociedade de indivíduos) e hierárquicas (uma sociedade de pessoas), o que fomentaria a existência de uma situação jurídica paradoxal que conjugaria princípios constitucionais liberais-igualitários com um sistema judicial hierárquico (DAMATTA; KANT DE LIMA apud CARDOSO DE OLIVEIRA, 2015, p. 169).

Conforme propõe Cardoso de Oliveira, há uma tensão entre duas concepções de igualdade no Brasil: 1) a concepção de igualdade presente na Constituição de 1988, segunda a qual todos são iguais perante a lei e 2) a concepção de igualdade enquanto tratamento diferenciado, expressa em uma célebre frase de Rui Barbosa: "A regra da desigualdade não consiste senão em favorece desigualmente aos desiguais na medida em que desigualam”.

La peculiaridad de esta última concepción em comparación com otras concepciones de igualdad vigentes em Occidente es que, para la realización de la igualdad em el plano de la justicia, se hace necessária la relativización o diferenciación de derechos em el plano de la ciudadanía, conforme al estatus y la condición social del ciudadano (CARDOSO DE OLIVEIRA, 2015, p. 169).

A partir dos ensinamentos de DaMatta e Kant de Lima, Lobão sugere que a aversão ao conflito na sociedade brasileira ocorre quando o plano hierárquico encontra-se em evidência (LOBÃO, 2000, p. 97). O Estado é chamado a intervir prontamente "porque o conflito demonstra sua fraqueza, a contestação do seu poder, 
a negação de sua autoridade. É o Estado que tem que ser forte, para manter a hierarquia, e não a sociedade que tem que ser organizada”.

Todavia, em determinados momentos da vida brasileira, o conflito não se apresenta enquanto problema. Há conflitos que são perfeitamente produtores de sociabilidade (SIMMEL, 1983, p. 122). Para Lobão, o problema surge quando o conflito ameaça a organização estrutural dada, a quebra da hierarquia (LOBÃO, 2010, p. 147). Se o conflito ameaça, por exemplo, a relação das partes em disputa com o Estado, tem-se um problema. O Estado terá que recolocar o mundo em ordem, restabelecendo a ordem existente.

\section{3.}

\section{Dramas sociais ou conflitos intratáveis?}

Uma outra dimensão do conflito poderá contribuir para a nossa empreitada. Para um grupo que se tem debruçado, notadamente, sobre questões ambientais (PUTNAM; WONDOLLECK, 2003), o conflito pode apresentar-se como um drama social ou como um conflito intratável.

Desenvolvido pelo antropólogo escocês Victor Turner, o conceito de drama social diz respeito a "unidades de processo anarmônico ou desarmônico que surgem em situações de conflito" (TURNER, 2008, p. 33). Para Turner, os dramas sociais possuem quatro fases de ação pública observáveis: a) ruptura; b) crise; c) ação corretiva; e d) reintegração. Na primeira fase, ocorre um rompimento das relações sociais dentro de um sistema, quer através de uma manifestação pública, quer pelo descumprimento de alguma norma que regula essas relações. Em seguida, há uma crise crescente, que pode ensejar um aumento da ruptura e da clivagem entre as partes envolvidas no drama. Na terceira etapa, a fim de limitar a difusão da crise, lança-se mão de mecanismos, como conselhos, mediação, arbitragem ou instrumentos jurídicos. Por fim, a última fase consiste "na reintegração do grupo social perturbado ou no reconhecimento e na legitimação social do cisma irreparável entre as partes em conflito" (Idem, p. 36).

Conflitos tratáveis são dramas sociais, a exemplo dos conflitos que são levados para o Judiciário, podendo culminar na ruptura ou na conciliação. É um 
tipo de conflito no qual não há dúvidas sobre o objeto em disputa. Cada uma das disputas dentro do conflito são compreendidas por todas as partes envolvidas.

Já a ideia de um conflito intratável é de outra ordem. Primeiramente, não há uma concordância quanto ao objeto em disputa, a exemplo dos conflitos socioambientais. Em segundo lugar, as representações ou significações mudam ao longo do tempo e não são compartilhadas por todos. As percepções acerca do conflito podem variar entre "tratabilidade" e "intratabilidade" (LOBÃO, 2010, p. 149).

No primeiro caso, contudo, a tratabilidade não significa que o conflito tenha sido solucionado; mas que os participantes encontraram algumas decisões aceitáveis e moveram-se em direção a questões mais centrais da disputa (PUTNAM; WONDOLLECK apud LOBÃO, 2010, p. 149). Já no que diz respeito à intratabilidade, os conflitos adquirem as seguintes características: a) longa duração; b) recusa em sua resolução; c) divisibilidade; d) intensidade; e) abrangência; e f) complexidade. Nesse sentido, "conflitos de longa duração são aqueles que possuem um passado extenso, um presente turbulento e um futuro obscuro" (LOBÃO, 2010, p. 149).

Um conflito pode se tornar intratável quando tentativas de negociação e mediação geram impasses, aumentando a intensidade do conflito. Pode ocorrer, também, quando os participantes passam a questionar acordos já celebrados ou quando os custos de uma solução são percebidos como maiores do que os custos da manutenção da disputa (PUTNAM; WONDOLLECK apud LOBÃO, 2010, p. 149).

Os contextos destes conflitos pertencem ao campo dos conflitos socioambientais, na medida em que "envolvem diferentes visões sobre os significados e direitos sobre espaços naturais e/ou necessários para a reprodução material, cultural e simbólica de grupos culturalmente diferenciados" (LOBÃO, 2014, p. 45).

O conflito observado na Praia de Piratininga ultrapassa a dimensão de um drama social, sendo dotado de causas e características próprias de conflitos intratáveis. Como vimos, os atores envolvidos representam o barracão de pesca de maneira diferente, de modo que não há um consenso acerca do objeto em disputa. Lá, a variação entre a tratabilidade e a intratabilidade do conflito acompanha a alternância sazonal entre inverno e verão. Embora as disputas aparentemente estejam resolvidas durante o inverno - período em que a clivagem parece diminuir, 
permanecendo na praia somente "quem é pescador" -, irrompem novamente durante o verão. Mas, na verdade, o conflito nunca é solucionado; há sempre um impasse quanto às regras estabelecidas. Sua intensidade aumenta ou diminui, mas jamais cessa completamente.

A peculiaridade de um conflito intratável é evidenciada quando percebemos que a mudança do objeto da disputa, dos atores envolvidos ou dos contextos não resulta necessariamente no fim do conflito. Um conflito intratável não cessa; ele é administrado. Não faz sentido, pois, reduzi-lo em enquadramentos jurídicos. São valores morais que estão em jogo; não valores legais. Eis a questão: como trabalhar com conflitos intratáveis dentro da perspectiva de não solucioná-los?

Utilizando-se do conceito de frame, Lobão atenta para as diferentes “significações" ${ }^{44}$ encontradas na análise de conflitos ambientais (LOBÃO, 2010, p. 150). Isso porque "as significações agem como lentes através das quais os litigantes interpretam a dinâmica do conflito e são estas interpretações que fazem com que o conflito seja mais ou menos tratável" (LEWICKI; GRAY apud LOBÃO, 2010, p. 150). Essas "lentes" podem permanecer estáveis no decorrer das disputas, de modo a reafirmar o conflito. Além disso, as diferentes significações interagem, podendo reforçar ou reduzir a intensidade do conflito: as partes podem não representar o problema e a administração deste da mesma forma.

Mais do que representar um modelo de administração de conflitos intratáveis, a ideia da significação diferenciada permite que se explicitem os conteúdos das disputas e os enunciados sobre elas. Evidenciam os recursos que são utilizados pelas partes na busca de potencializar seus argumentos. O que nos leva de volta para questões que envolvem poderes e potências com graus distintos de eficácia e alcance (LOBÃO, 2010, p. 151-152).

\section{4.}

\section{De olho no "olho grande"}

Em Piratininga, um dos mecanismos pelos quais os pescadores explicitam a existência do conflito é a enunciação da categoria olho grande. Conforme descrevi

\footnotetext{
${ }^{44}$ Para uma justificativa da tradução do conceito de frame como "significação", e não como "quadro", como é mais corrente nas Ciências Sociais, ver a nota de rodapé número 27 em LOBÃO, 2010, p. 150.
} 
na primeira parte, enquanto atributo, o sujeito "olho grande" (ou "olhudo") é aquele que prefere pescar individualmente para não ter que compartilhar a captura, além de manter segredos a respeito de pesqueiros ou da quantidade e das espécies que capturou. Ele também não é solidário com quem lhe ajudou ou com quem lhe pede um punhado de peixe. $\mathrm{O}$ "olho grande" utiliza instrumentos "não-tradicionais" e "faz comércio" na praia, ao invés de se dedicar à pescaria.

Em alguns bairros periféricos de Porto Alegre, Cláudia Fonseca observou que a expressão "olho grande" "serve para explicar ao mesmo tempo os empreendimentos ambiciosos e seu fracasso" (FONSECA, 2004, p. 108). Como em Piratininga, ele pode designar tanto ambições desmesuradas quanto forças externas que levam os ambiciosos a fracassar - lembrem-se do pescador desafortunado que, ao crescer o olho, não obteve mais êxitos nas pescarias. No primeiro caso, o adjetivo recai sobre um indivíduo; no segundo, torna-se impessoal e estende-se para todo o grupo ("aqui só tem olho grande").

O verbete "olho grande" consta no Dicionário do folclore brasileiro, de Luís da Câmara Cascudo. Sinônimo de "olho mau, passível de irradiação maléfica", trata-se de "uma das maiores prevenções alimentadas pela superstição popular na Amazônia, como aliás em todo o Brasil” (CASCUDO, 1972, p. 613). A presença de rituais preventivos ou capazes de reverter os efeitos do "olho grande" foi constatada, igualmente, em religiões de matriz africana, como na umbanda (BIRMAN, 1980) e no candomblé (MAGGIE, 2001).

A meu ver, o "olho grande" pode ser interpretado como um mecanismo de controle utilizado para combater determinadas insígnias da ideologia moderna (DUMONT, 1993). Nas situações que se desenrolam em Piratininga, a categoria se opõe ao individualismo daqueles que tentavam recusar as relações hierárquicas, subvertendo os papeis socialmente estabelecidos. O indivíduo, entendido enquanto valor do pensamento moderno (DUMONT, 1993, p. 240), recusa as atividades coletivas, assim como o compartilhamento de experiências e informações. O princípio individualista é uma afronta à organização estrutural estabelecida.

As reinvindicações de "igualdade" de "liberdade" surgem quando "todo mundo tem o direito de ganhar o seu" ou "se ele faz comércio, por que eu não posso fazer?". Todos são "iguais" e "livres" para explorar o "espaço público" da praia, inclusive para dispor desse espaço como se "propriedade privada" o fosse lembremos das apropriações particularizadas do barracão de pesca. No entanto, 
contra a trinca "igualdade", "liberdade" e "propriedade" insurge-se um princípio hierárquico que tem na explicitação do "olho grande" uma forma de se coibir a predominância do princípio individualista.

A despeito dos "avanços" tecnológicos, do "progresso" e do "desenvolvimento", as sociedades contemporâneas não estão totalmente submersas na ideologia moderna, do mesmo modo que a economia de mercado não engolfou todas as relações sociais (POLANYI, 2012; CLASTRES, 2015). Nesse sentido, os usos e apropriações dos espaços em Piratininga podem ser entendidos como o "resultado de uma história em cujo transcurso modernidade e não modernidade ou, mais exatamente, as ideias-valores individualistas e suas contrárias combinam-se intimamente" (DUMONT, 1993, p. 31). Contudo, como toda relação conjugal que se preze, o casamento entre individualismo e holismo não está incólume aos conflitos. 


\section{7.}

\section{Considerações finais}

Meu diálogo se deu com os pescadores da Praia de Piratininga - mas, indiretamente, espero ter dialogado com você, leitor. Tentei compreender algumas dimensões da vida desse grupo, principalmente a maneira pela qual as relações conflituosas são construídas na praia. Assim, o objeto deste trabalho foram os diferentes usos e apropriações do barracão de pesca, com o foco voltado para uma situação específica: o conflito envolvendo pescadores que exercem diferentes artes de pesca e barraqueiros.

Esse conflito, que engloba uma série de disputas que ocorrem nos espaços da praia, pode ser compreendido pela tensão entre os inúmeros sentidos que são atribuídos ao barracão por diferentes atores, cujos interesses também são díspares. A cada sentido e interesse correspondem formas diferenciadas de legitimar a ocupação e, consequentemente, diferentes usos e apropriações de um mesmo espaço. Temos aí uma disputa política, dentro da qual os participantes lutam pela autoridade própria do autor, isto é, pelo poder de definir o que significa e como se deve/pode ocupar aquele espaço.

Mais do que um drama social, o conflito em Piratininga apresenta-se como um conflito intratável. Se durante o inverno há uma resolução aparente, no verão o conflito irrompe novamente, reproduzindo não somente uma alternância sazonal, mas uma forma de sociabilidade que permeia a estrutura do grupo. O conflito é reforçado constantemente, na medida em que os contendores representam de maneira diferente o objeto em disputa. Além disso, há sempre um impasse quanto às regras estabelecidas. $\mathrm{E}$, mesmo que haja uma mudança dos atores e do objeto, o conflito ainda estará presente.

Os pescadores convivem, portanto, com uma constante ameaça ao princípio hierárquico que norteia sua organização. De um lado, temos uma perspectiva holística, através da qual cada parte relaciona-se com um todo, desempenhando papeis específicos, como os lugares de uma canoa explicitam. De outro, uma perspectiva moderna aliada a um princípio individualista. Nesse último caso, uma arte de pesca mais individualizada como a rede de espera poderia representar a recusa das relações hierárquicas. 
Entretanto, esses dois paradigmas de sociedade não estão tão apartados quanto imaginamos. A pesca de rede de espera não prescinde de vínculos de reciprocidade, de uma rede de relações de parentesco, vizinhança, amizade e compadrio. Do mesmo modo, o barracão não está reduzido simplesmente a uma propriedade, passível de negociação na economia de mercado. Para que um espaço seja transformado em lugar, basta que a atitude prosaicista não elimine a topofilia.

O fim comercial ao qual tem sido destinado, pode significar tanto uma possibilidade de reprodução - de sobrevivência - do modo de vida daqueles pescadores quanto sua extinção. As mudanças sociais ocorrem, fomentadas pelos atores ou independentemente de suas vontades. Mas há sempre traços holísticos mesmo onde a modernidade é anunciada como o único caminho possível. 


\section{8. \\ Referências bibliográficas}

BIRMAN, P. Feitiço, carrego e olho grande, os males do Brasil são: estudo de um centro umbandista numa favela do Rio de Janeiro. 1980. Dissertação (mestrado em Antropologia Social) - Museu Nacional, Universidade Federal do Rio de Janeiro, Rio de Janeiro. 1980.

BOISSEVAIN, J. Apresentando "amigos de amigos: redes sociais, manipuladores e coalizações". In: FELDMAN-BIANCO, B. Antropologia das sociedades contemporâneas: métodos. São Paulo: Editora UNESP, 2010.

BOURDIEU, P. Sobre o poder simbólico. In: 0 poder simbólico. Edições 70: Lisboa, 2015.

BRITTO, R. C. Modernidade e tradição. Niterói, RJ: EDUFF, 1999.

CAMPOS, M. C. $O$ governo da cidade: elites locais e urbanização em Niterói (1835-1890). 2004. 304 f. Tese (doutorado em História) - Instituto de Ciências Humanas e Filosofia, Universidade Federal Fluminense, Niterói. 2004.

CARDOSO DE OLIVEIRA, L. Ciudadania, derechos y diversidade. Desacatos, n. 48, p. 168-191, 2015.

CASCUDO, L. C. Dicionário do folclore brasileiro: J-Z. 3. ed. Instituto Nacional do Livro: Brasília, 1972.

CLASTRES, P. Arqueologia da violência - pesquisas de antropologia política. 3. ed. São Paulo: Cosac Naify, 2015.

COLAÇO, J. Quanto custa ser pescador artesanal? Etnografia, relato e comparação entre dois povoados pesqueiros no Brasil e em Portugal. 2012. $337 \mathrm{f}$. Tese (doutorado em Antropologia) - Instituto de Ciências Humanas e Filosofia, Universidade Federal Fluminense, Niterói. 2012.

DAMATTA, Roberto. A casa e a rua: espaço, cidadania, mulher e morte no Brasil. Rio de Janeiro: Rocco, 1997a.

- Carnavais, malandros e heróis. Rio de Janeiro:

Rocco. 1997. 
Fé em Deus e pé na tábua: como e por que o trânsito enlouquece no Brasil. Rio de Janeiro: Rocco, 2010.

DARDEL, E. O homem e a terra: natureza da realidade geográfica. São Paulo: Perspectiva, 2011.

DUMONT, L. Homo hierarchicus - o sistema de castas e suas implicações. São Paulo: Editora da Universidade de São Paulo, 2008.

O individualismo: uma perspectiva antropológica da ideologia moderna. Rio de Janeiro: Rocco, 1993.

DURKHEIM, É. Da divisão do trabalho social. São Paulo: Martins Fontes, 2013.

DURKHEIM, É.; MAUSS, M. Algumas formas primitivas de classificação. In: RODRIGUES, J. A. (Org.). Émile Durkheim: sociologia. São Paulo: Ática, 1981.

ERIKSEN, T. H.; NIELSEN, F. S. História da antropologia. Petrópolis, RJ: Vozes, 2010.

FILGUEIRAS, M. Entre pescarias e meio ambiente: alguns usos e representações sobre os barracões da Praia da Concha (Vila Velha-ES). In: Reunião Brasileira de Antropologia, 26ª , 2008. Porto Seguro, Bahia. Anais... Porto Seguro, 2008.

FIRTH, R. Elementos de organização social. Rio de Janeiro: Zahar, 1974. FONSECA, C. Família, fofoca e honra: etnografia de relações de gênero e violência em grupos populares. 2. ed. Porto Alegre: Editora da UFRGS, 2004.

FREYRE, G. Sobrados e mucambos: decadência do patriarcado e desenvolvimento do urbano. 15. ed. São Paulo: Global, 2012.

GERBER, R. M. Uma aventura antropológica: a perda da inocência. Cadernos de campo, São Paulo, n. 23, p. 47-60, 2014.

GEERTZ, C. Uma descrição densa: por uma teoria interpretativa da cultura. In: A intepretação das culturas. Rio de Janeiro: LTC, 2014. GOVERNO DE NITERÓl. Projeto orla Niterói - dossiê, 2011. HIRSCHMAN, A. O. As paixões e os interesses: argumentos políticos a favor do capitalismo antes do seu triunfo. Rio de Janeiro: Record, 2002 HOLANDA, S. B. Raízes do Brasil. 26. ed. São Paulo: Companhia das Letras, 2006. 
HOUAISS, A. Dicionário Houaiss da língua portuguesa. Rio de Janeiro: Objetiva, 2001.

KANT DE LIMA, R. Sensibilidades jurídicas, saber e poder: bases culturais de alguns aspectos do direito brasileiro em uma perspectiva comparada. Anuário Antropológico/2009, n. 2, p. 25-51, 2010.

KANT DE LIMA, R.; PEREIRA, L. F. Pescadores de Itaipu: meio ambiente, conflito e ritual no litoral do Rio de Janeiro. Niterói, EDUFF, 1997.

KANT DE LIMA, R. et al. Uma visão multidisciplinar sobre políticas públicas - uma quarta fase na produção bibliográfica sobre pescarias e pescadores. In: Reunião de Antropologia do Mercosul, 7, 2007, Porto Alegre, RS, Anais... Porto Alegre, 2007.

KUPER, A. Cultura: a visão dos antropólogos. Bauru, SP: EDUSC, 2002.

LÉVI-STRAUSS, C. O pensamento selvagem. São Paulo: Papirus, 1989. LOBÃO, R. Cosmologias políticas do neocolonialismo: como uma política pública pode se transformar em uma política de ressentimento. Niterói: Editora da Universidade Federal Fluminense, 2010.

. Notas em favor de um programa de pesquisa de antropologia no direito em contextos de jusdiversidade. Democracia y Derechos, Año 3, n. 5, Buenos Aires, 2014.

Reservas extrativistas marinhas: uma reforma agrária no mar? - uma discussão sobre o processo de consolidação da reserva extrativista marinha de Arraial do Cabo/RJ. 2000. 112 f. Dissertação (Mestrado em Antropologia e Ciência Política) - Universidade Federal Fluminense, Niterói. 2000.

LOTO, L. Reservas extrativistas marinhas vs. áreas de manejo e exploração de recursos bentônicos: comparação de modelos de gestão compartilhada de áreas marinhas protegidas no Brasil e no Chile. 2012. 233 f. Dissertação (Mestrado em Sociologia e Direito) - Faculdade de Direito, Universidade Federal Fluminense, Niterói. 2012.

MACHADO, E. R. Governança urbana no município de Niterói - RJ: a emergência de territorialidades e conflitos em Camboinhas. 2011. $118 \mathrm{f}$. Dissertação (Mestrado em Geografia) - Instituto de Geografia, Universidade do Estado do Rio de Janeiro, Rio de Janeiro. 2011. 
MAGGIE, Y. Guerra de orixá: um estudo de ritual e conflito. 3. ed. Rio de Janeiro: Jorge Zahar, 2001.

MANESCHYIN, M. C. Mulheres na pesca artesanal: trajetórias, identidades e papéis em um porto pesqueiro no litoral do estado do Pará. In: NEVES, D. P.; MEDEIROS, L. S. (Orgs.). Mulheres camponesas: trabalho produtivo e engajamentos políticos. Niterói: Alternativa, 2013.

MARANDOLA JR, E. Prefácio à edição brasileira. In: 0 homem e a terra: natureza da realidade geográfica. São Paulo: Perspectiva, 2011.

MAUSS, M. As técnicas do corpo. In: Sociologia e antropologia. São Paulo: Cosac Naify, 2013

Ensaio sobre as variações sazonais das sociedades esquimós. In: Sociologia e antropologia. São Paulo: Cosac Naify, 2013 MELLO, M. A. S; VOGEL, A. Gente das areias: história, meio ambiente e sociedade no litoral brasileiro. Maricá, RJ - 1975 A 1995. Niterói, EDUFF, 2004.

MELLO, M. A. S. et al. Quando a rua vira casa: a apropriação de espaços de uso coletivo em um centro de bairro. Rio de Janeiro: IBAM/FINEP, 1981. MIBIELLI, B. L. Mestre Cambuci e o "sumiço da tainha": uma nova imagem da praia de Itaipu. 2004. 56 f. (Bacharelado em Ciências Sociais) - Instituto de Ciências Humanas e Filosofia, Universidade Federal Fluminense, 2004.

Ser "pescador profissional artesanal tradicional de Itaipu": e as redes de relações de uma trajetória. 2014. 101 f. Dissertação (Mestrado em Sociologia e Direito) - Faculdade de Direito, Universidade Federal Fluminense, Niterói. 2014.

MORAES, A. C. R. Ideologias geográficas: espaço, cultura e política no Brasil. São Paulo: Annablume, 2005.

MOTA, F. R. Nem muito mar, nem muita terra. Nem tanto negro, nem tanto branco: uma discussão sobre o processo de construção da identidade da comunidade remanescente de quilombos na llha da Marambaia. 2003. 172 f. Dissertação (mestrado em Antropologia) - Instituto de Ciências Humanas e Filosofia, Universidade Federal Fluminense, Niterói, 2003. 
O'DONNELL, J. A invenção de Copacabana: culturas urbanas e estilos de vida no Rio de Janeiro (1890-1940). Rio de Janeiro: Zahar, 2013.

OLIVERA, L. P. H. de. Estudo hidrobiológico das Lagôas de Piratininga e Itaipú. In: Memórias do Instituto Oswaldo Cruz. Tomo 46(f4), p. 673-718, 1948.

PESSANHA, E. G. F. Os companheiros: trabalho e sociabilidade na pesca de Itaipu. Niterói: EDUFF, 2003.

PIMENTEL, L. A. Topônimos tupis de Niterói. Niterói: Traço \& Photo Editora, 2001.

POLANYI, K. A grande transformação: as origens da nossa época. 2. ed. Rio de Janeiro: Elsevier, 2012.

PRADO, S. M. Da anchova ao salário mínimo: uma etnografia sobre injunções de mudança social em Arraial do Cabo-RJ. Niterói: EDUFF, 2002. SAHLINS, M. Ilhas de histórias. Rio de Janeiro: Jorge Zahar Editor, 1990. SARAIVA, Joana Martins. Saber pescar, saber trabalhar: uma discussão sobre a identidade social dos pescadores de rede de arrastão na praia de Piratininga. 2004. Monografia (Bacharelado em Ciências Sociais) Universidade Federal Fluminense, Niterói. 2004.

SENNETT, Richard. Autoridade. Rio de Janeiro: Record, 2001.

SILVA, G. O. Tudo que tem na terra tem no mar: a classificação dos seres vivos entre trabalhadores da pesca em Piratininga. Rio de Janeiro: Editora FUNARTE, 1989.

SIMMEL, G. A metrópole e a vida mental. In: VELHO, O. G. (Org.). 0 fenômeno urbano. Rio de Janeiro: Zahar, 1976.

As grandes cidades e a vida do espírito. Disponível em: http://www.lusosofia.net/textos/simmel_georges_grandes_cidades_e_vida _do_esp_rito.pdf. Acesso em: 28 dez. 2015.

A natureza sociológica do conflito. In: MORAES FILHO, E. (Org.). Simmel: sociologia. São Paulo: Ática, 1983.

SINCLAIR, A. A construção legal de identidades: a reificação da identidade de pescador em Itaipu. In: IV ENADIR, GT número 13. Povos Indígenas e Comunidades Tradicionais perante o direito: práxis jurídica, 2015. 
SINDER, V. A (autor)idade da escrita: etnografia e narrativa. Travessia Revista de Literatura, UFSC, Florianópolis, n. 29/30, p. 291-323, 1997.

STEVENSON, I. A. De onde vem o mexilhão? Etnografia na beira da Baía de Guanabara de um grupo de "marisqueiros" em Niterói. In: Reunião Brasileira de Antropologia, 29ª 2014. Natal, RN. Anais... Natal, 2014.

TARDELLI, G. Uma etnografia de um barracão de pesca. In: Encontro Anual da ANPOCS, 40ํ․ 2016. Caxambu, MG, Anais... Caxambu, 2016.

TARDELLI, G.; STEVENSON, I. Visões sobre o mexilhão: análise comparativa entre a Praia de Piratininga e a Praia Grande em Niterói, RJ. In: Encontro Nacional de Estudos do Consumo, 8ㅜ, 2016. Niterói, RJ, Anais... Niterói, 2016.

TUAN, Y. F. Topofilia: um estudo da percepção, atitudes e valores do meio ambiente. Londrina: Eduel, 2012.

TURNER, V. Dramas, campos e metáforas: ação simbólica na sociedade humana. Niterói: EDUFF, 2008

VIVAS, P. Polícia investiga incêndio na praia, barracão onde pescadores da colônia Z7 guardavam barcos e material de mergulho foi completamente destruído pelas chamas, O Fluminense, Niterói, 1 jul. 2014, Geral.

WEHRS, Carlos. Niterói cidade sorriso: história de um lugar. Rio de Janeiro [s.n.], 1984.

WOLF, E. R. Encarando o poder: velhos insights, novas questões. In: FELDMAN-BIANCO, B.; RIBEIRO, G. L. (Orgs.). Antropologia e poder. Brasília: Editora Universidade de Brasília: São Paulo: Imprensa Oficial do Estado de São Paulo: Editora Unicamp, 2003.

\section{1.}

\section{Legislações}

BRASIL. Decreto no 124, de 9 de janeiro de 1890.

BRASIL. Decreto no 5.051, de 19 de abril de 2004.

BRASIL. Lei no 11.959, de 29 de junho de 2009.

BRASIL. Portaria do SPU no 89, de 15 de abril de 2010.

BRASIL. Resolução do Conama no 07, de 23 de julho de 1996. 
RIO DE JANEIRO. Decreto no 44.417, de 30 de setembro de 2013.

RIO DE JANEIRO. Portaria do INEA/Dibap no 42, de 14 de março de 2014. NITERÓI. Lei municipal no 1.157, de 4 de fevereiro de 1992. 


\section{9.}

\section{Glossário}

Abertura da barra: operação durante a qual os pescadores abriam um canal ligando a lagoa e o mar, a fim de regular o ciclo biológico da lagoa.

Amigos: aqueles que são bem quistos pelos pescadores; quem é de fora do grupo, mas consegue manter com o mesmo boas relações.

Arrasto de praia (ou arrastão): arte de pesca que utiliza as tradicionais canoas de "um tronco só"; subdivide-se nas modalidades do lanço à sorte e do cerco com vigia.

Arrastão: o mesmo que arrasto de praia.

Arriar: operação de colocar a embarcação no mar, empurrando-a sobre as estivas ou rolos.

Banhista: moradores do bairro de Piratininga ou turistas (moradores de outras localidades) que vêm para a praia nos fins de semana e feriados, principalmente durante o verão.

Barcos: embarcações de madeira ou alumínio, que medem entre 4,2 e 6 m de comprimento.

Barracão: edificação localizada na praia e improvisada com diferentes tipos de materiais e técnicas de construção; local de armazenamento de petrechos e venda do pescado; local de venda de comidas e bebidas; espaço de disputa entre pescadores e barraqueiros.

Barraqueiro: homens e mulheres que dispõem mesas, cadeiras e barracas nas areias da praia, com a finalidade de atender comercialmente os banhistas durante o verão; quem vende comidas e bebidas nas areias da praia.

Bicheiro: petrecho utilizado na captura do polvo, lagosta e cavaca, que consiste em uma vara de metal com um anzol no extremo.

Cabeiro: aquele que, durante o arrasto de praia, se responsabiliza pela ponta do cabo que se prende à rede; quem participa da pescaria sem ir para o mar. Canoas: tradicionais canoas "de um tronco só" (feitas de troncos cavados), que medem cerca de $7 \mathrm{~m}$ de comprimento e utilizam apenas remos; embarcação utilizada na pescaria de arrastão. 
Cavadeira: petrecho utilizado na mariscagem de mexilhão; consiste em uma vara de madeira com um pedaço retangular de metal na extremidade Cerco com vigia: modalidade de arrasto de praia que conta com a figura do vigia na companha; arte de pesca durante a qual se faz um semicírculo com a rede na beira da praia, puxando-a em seguida.

Companha: grupo de pescadores que se reúne para realizar as pescarias de arrasto de praia; organização dotada de relações hierárquicas e de uma divisão social do trabalho; o mesmo que equipe.

Companheiro: aquele que é membro de uma companha ou de uma equipe.

Corre: ato de se vender o pescado excedente diretamente nas casas de moradores locais ou em bares e restaurante; é realizado por quem não é pescador, espécie de intermediário que ganha um percentual sobre a venda.

Correria: o mesmo que corre.

Corvineira: redes baixa (que opera no fundo mar), que tem de 700 a 800 $\mathrm{m}$ de comprimento, $2 \mathrm{~m}$ de altura e cujos panos variam de malha entre 45 , $50,55,60$, até $75 \mathrm{~cm}$; rede utilizada na captura da corvina e de outros peixes de porte semelhante.

Cata-cata: recrutamento aleatório e improvisado de pescadores; tentativa de se reunir um determinado número de pescadores para participar de uma pescaria.

De fora: aquele que não mora no bairro de Piratininga; aqueles que moram no bairro de Piratininga mas não são pescadores.

Direito à vez: regra local que possibilitava uma alternância entre as canoas que fariam as pescarias de arrasto de praia.

Encalhar: operação de tirar a embarcação do mar e empurrá-la para a areia.

Equipe: o mesmo que companha.

Estivas: tocos de madeira que recebem uma pincelada de sebo, para que a canoa deslize com mais facilidade durante a operação de encalhar e desencalhar. 
Fieira: petrecho utilizado na captura do polvo; consiste em um arame que atravessa o polvo, fechado com uma volta na extremidade para evitar que o mesmo escape.

Desencalhar: o mesmo que arriar.

Dono: membro da companha; proprietário do conjunto de aparelhos que compõe a pescaria.

Ilha do Veado: ilha situada em frente à Prainha; o nome se deve à presença, em seu interior, de árvores de figueira, cujos galhos assemelham-se aos chifres de um veado.

Ilhota: pequena ilha situada na Lagoa de Piratininga Lancha

Lanço à sorte: modalidade de arrasto de praia; chama-se "à sorte" porque se faz um cerco sem saber que tipo de peixe será pescado.

Leme: instrumento utilizado pelo mestre para controlar a direção da canoa. Linguadeira: rede baixa (que opera no fundo do mar), que tem de 250 a $300 \mathrm{~m}$ de comprimento, $2 \mathrm{~m}$ de altura e malha de $110 \mathrm{~cm}$; rede voltada para a captura do linguado ou de peixes maiores.

Maré: alterações do nível das águas do mar causadas pela interferência gravitacional da Lua e do Sol sobre o campo gravítico da Terra; um punhado de peixes, que podem estar agrupados na mesma espécie ou em espécies diferentes; a parcela que se rebe após a participação em uma pescaria.

Mestre: membro da companha responsável pela pescaria; quem decide como será executada a pescaria e determina o ritmo e a velocidade a ser imprimida pela canoa; o responsável pela distribuição e comercialização do produto.

Nitheroy: topônimo tupi significa que "água escondida"; grafia antiga da cidade de Niterói.

Olho grande: adjetivo atribuído à quem não quer ter um companheiro de pesca para não ter que dividir o quinhão; à quem não revela pesqueiros onde está "dando" peixe ou não mostra o que foi capturado; à quem não distribui o pescado, seja com alguém que contribuiu nas operações de encalhar e desencalhar a embarcação, seja com alguém que pediu um peixe "para almoçar"; à quem pesca eventualmente e apenas após 
constatar que alguém "se deu bem"; à quem utiliza petrechos "nãotradicionais"; à quem "faz comércio" na praia.

Olhudo: o mesmo que olho grande.

Pedra da Baleia: formação rochosa situada em frente à Prainha.

Pescaria: conjunto de equipamentos utilizados durante a pesca (embarcação, redes, remos, motor etc.); ato de pescar.

Pesqueiro: designação dada a uma formação rochosa chamada de laje, situada no fundo mar, embaixo da qual os peixes ficam; "é a morada dos peixes", "é o lugar onde os peixes dormem".

Piratininga: nome de origem tupi que significa "secagem de peixe" ou "peixe a secar"; nome do bairro e da praia do mesmo bairro.

Ponta da Galheta: Formação rochosa que divide a Prainha do Praião.

Porto lagoa: porto é a categoria utilizada para designar uma determinada área onde o pescador "joga" a rede de tarrafa, voltada à pesca do camarão (daí também o chamarem de porto para camarão)

Porto praia: lugar onde ocorre a entrada e a saída de embarcações

Prainha: trecho menor da Praia de Piratininga, onde estão localizados o barracão e o núcleo de pescadores.

Puçá: armadilha feita por um aro de metal que assenta no fundo e uma rede de $20 \mathrm{~cm}$ de malha em forma de funil, com uma boia que fica sobre a superfície da água.

Puxada de rede: operação de puxar a rede na areia da praia, após a realização do cerco; etapa que conta com a participação tanto dos membros da companha quanto de voluntários.

Quinhão: aquilo que cada pescador recebe pela participação em uma pescaria; parte do rendimento obtido com a pesca.

Re-cabo: petrecho utilizado durante a puxada de rede; consiste em um laço do qual se destaca um pedaço de corda com cerca de $50 \mathrm{~cm}$ - a parte circular é posta na cintura e o pedaço é entrelaçado na corda que compõe a rede.

Rede alta: rede que opera na superfície voltada para a captura de peixes que nadam próximos à superfície da água; petrecho que tem cerca de 250 $\mathrm{m}$ a $300 \mathrm{~m}$ de comprimento, $4 \mathrm{~m}$ de altura e malha entre 50 e $55 \mathrm{~cm}$.

Rede baixa: ver corvineira e linguadeira. 
Rede de arrastão: rede utilizada nas pescarias de cerco com vigia e lanço à sorte; petrecho com cerca de $800 \mathrm{~m}$ de comprimento, $10 \mathrm{~m}$ de altura $\mathrm{e}$ com malha entre 40 e $50 \mathrm{~cm}$ nas laterais da rede e $10 \mathrm{~cm}$ no cópio.

Rede de cerco: ver rede de arrastão.

Rede de espera: arte de pesca praticada na praia; é realizada por uma ou duas pessoas e consiste em deixar a rede esticada no fundo, fixa em ambos os extremos por âncoras e sinalizada por boias e, às vezes, por duas bandeiras. A rede é recolhida no início do dia para se tirar a captura (cobrar a rede). Se o mar estiver em boas condições, colocam-na novamente. Mas, se tiver pouco peixe, deslocam a rede para outro local; havendo previsão de temporal, retira-se a rede da água.

Rede de malha: arte de pesca praticada na lagoa; rede de 200 m de comprimento e com malha de $30 \mathrm{~cm}$.

Rede de tarrafa: rede circular com aproximadamente $3 \mathrm{~m}$ de comprimento, com malha 10-12 cm, com chumbos cilíndricos distribuídos na circunferência e uma corda no centro para recolher as capturas.

Remada: operação de colocar a embarcação em movimento com o auxílio de remos.

Remador: aquele que movimenta a embarcação com o auxílio de remos. Remeiro: o mesmo que remador.

Restinga: área localizada atrás do barracão, delimitada por vegetações, onde foram plantados coqueiros, arbustos e muitas mudas de plantas; espaço de lazer e socialização.

Rolo: tubo oco e aberto feito de policloreto de vinil (Polyvinyl chloride $P V C$ ) com aproximadamente $25 \mathrm{~cm}$ de diâmetro; peça sobre a qual as embarcações são empurradas durante as operações de encalhar e desencalhar.

Timão: o mesmo que leme.

Turma: classificação utilizada pelos pescadores para se referir àqueles que são de fora; geralmente, vem acompanhada de uma localidade (Jurujuba, Cafubá, favela etc.) e é pronunciada em situações de oposição em relação a normas e comportamentos locais; podem ter uma conotação negativa. 
Vara: petrecho utilizado na pesca de linha; haste à qual se acopla um molinete ou carretilha (espécie de carretel no qual se enrola uma linha de nylon.

Vigia: membro da companha responsável por avistar, identificar e, às vezes, quantificar o cardume durante a pescaria de arrastão; aquele que se posicionava sobre uma pedra para determinar onde e o momento de se realizar o cerco. 